\title{
MAPEAMENTO DE QTL PARA DESEMPENHO E CARACTERÍSTICAS DE CARCAÇA, NOS CROMOSSOMOS 3 E 5 DE Gallus gallus
}

\author{
DEBORAH CLEA RUY
}

Tese apresentada à Escola Superior de Agricultura "Luiz de Queiroz", Universidade de São Paulo, para obtenção do título de Doutor em Agronomia, Área de Concentração: Ciência Animal e Pastagens

\author{
PIRACICABA \\ Estado de São Paulo - Brasil
}

Abril -2004 


\title{
MAPEAMENTO DE QTL PARA DESEMPENHO E CARACTERÍSTICAS DE CARCAÇA, NOS CROMOSSOMOS 3 E 5 DE Gallus gallus
}

\author{
DEBORAH CLEA RUY \\ Médica Veterinária
}

Orientador: Prof. Dr. LUIZ LEHMANN COUTINHO

Tese apresentada à Escola Superior de Agricultura "Luiz de Queiroz", Universidade de São Paulo, para obtenção do título de Doutor em Agronomia, Área de Concentração: Ciência Animal e Pastagens

\author{
PIRACICABA \\ Estado de São Paulo - Brasil
}

Abril -2004 
Dados Internacionais de Catalogação na Publicação (CIP)
DIVISÃO DE BIBLIOTECA E DOCUMENTAÇÃO - ESALQ/USP

Ruy, Deborah Clea

Mapeamento de QTLs para desempenho e características de carcaça, nos cromossomos 3 e 5 de Gallus gallus / Deborah Cléa Ruy. - - Piracicaba, 2004.

$122 \mathrm{p}$.

Tese (doutorado) - Escola Superior de Agricultura Luiz de Queiroz, 2004.

Bibliografia.

1. Carcaça 2. Cromossomo 3. Galinha 4. Genoma 5. Mapeamento genético 6. Marcador molecular I. Título

CDD 636.50824 


\section{Dedicatória}

A minha família, em especial a meus pais, que me apoiaram mesmo isso implicando em longos períodos de distância. 


\section{AGRADECIMENTOS}

Ao Prof. Dr. Luiz Lehmann Coutinho, pela orientação, provisão e confiança depositada.

A Dra. Mônica Corrêa Ledur, pela orientação e apoio.

As colegas Erica Elias Baron e Kátia Nones, pela amizade e companheirismo nesses anos de trabalho.

Aos estagiários Raquel L. R. Campos e Marcel Ambo, pelo auxílio e amizade. A todos que passaram pelo Laboratório de Biotecnologia Animal da ESALQ durante minha estada aqui, pela agradável convivência.

Aos Profs. Dr. Antonio Augusto Franco Garcia e Dr. Irineu Umberto Packer pelo valioso aconselhamento durante a condução do trabalho.

A Universidade de Brasília, em especial àqueles que possibilitaram minha vinda e permanência aqui.

A CAPES, pela concessão de bolsa de apoio.

Ao Milton Luiz Moreira Lima, pelo apoio e carinho.

A todos que de alguma maneira contribuíram para a realização deste trabalho. 


\section{SUMÁRIO}

Página

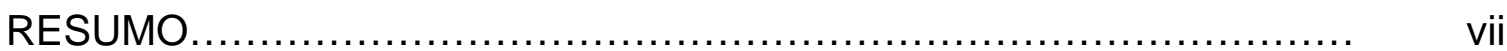

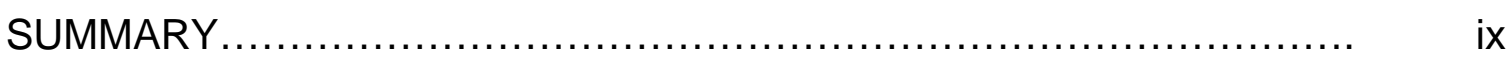

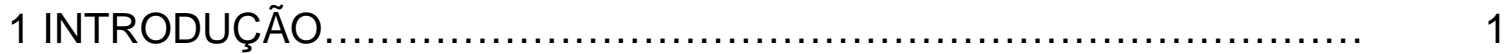

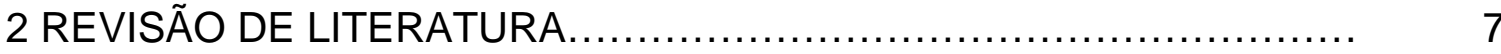

2.1 Caracterização do genoma da galinha (G. gallus)......................... 7

2.2 Marcadores moleculares e mapas genéticos........................... 9

2.3 QTL e fatores que afetam sua ligação com o marcador................ 16

2.4 Genotipagem seletiva............................................ 23

2.5 Métodos estatísticos para mapeamento de QTLs...................... 29

2.5.1 Métodos de mapeamento........................................................ 29

2.5.2 Níveis de significância e intervalo de confiança................................ 36

2.6 Populações-referência e o mapa consenso................................ 37

2.7 QTL identificados em galinhas..................................... 41

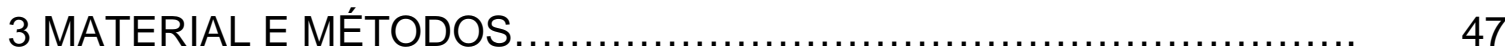

3.1 População experimental.............................................. 47

3.2 Coleta dos dados fenotípicos e do sangue das aves.................... 50

3.3 Extração do DNA genômico........................................... 53

3.4 Escolha dos marcadores microssatélites.............................. 53

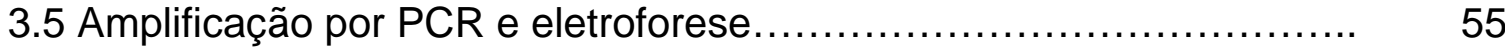

3.6 Estratégia de genotipagem.............................................. 57

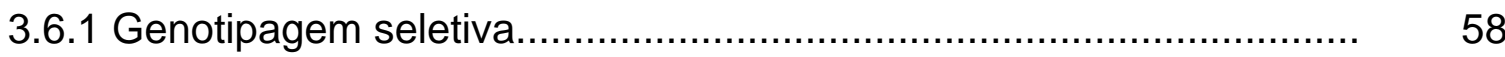

3.7 Determinação de heterozigosidade e PIC ................................ 60 
3.8 Procedimentos estatísticos............................................ 60

3.8.1 Ajuste de dados fenotípicos e correlações.................................... 60

3.8.2 Uso do teste de qui-quadrado.................................... 61

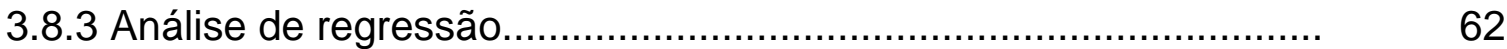

3.9 Determinação dos mapas de ligação...................................... 65

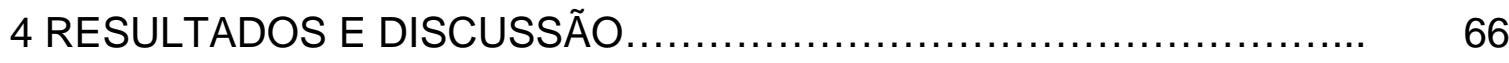

4.1 Extração do DNA e amplificação dos marcadores......................... 66

4.2 Marcadores informativos, heterozigosidade e PIC ..................... 70

4.3 Análise estatística dos dados fenotípicos............................... 73

4.4 Genotipagem seletiva............................................... 76

4.5 Construção dos mapas de ligação..................................... 82

4.6 Identificação de QTL............................................... 88

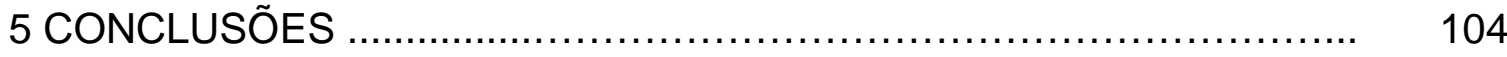

REFERÊNCIAS BIBLIOGRÁFICAS .................................... 105

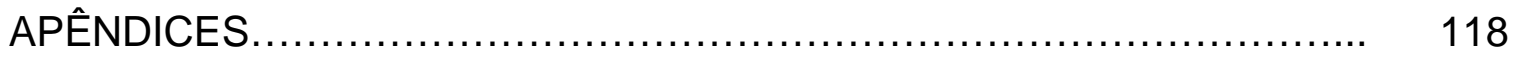




\title{
MAPEAMENTO DE QTL PARA DESEMPENHO E CARACTERÍSTICAS DE CARCAÇA, NOS CROMOSSOMOS 3 E 5 DE Gallus gallus
}

\author{
Autora: DEBORAH CLEA RUY \\ Orientador: Prof. Dr. LUIZ LEHMANN COUTINHO
}

\section{RESUMO}

Uma população experimental F2 foi desenvolvida a partir do cruzamento de sete machos de uma linhagem não endogâmica de frangos de corte (TT), com sete fêmeas de uma linhagem não endogâmica de postura (CC), gerando vinte famílias F1 TC, com aproximadamente 100 progênies F2 cada obtidas em 17 incubações. Foram obtidos dados fenotípicos para vinte e oito características de desempenho e qualidade da carcaça em 2063 aves F2. As aves F1 TC foram genotipadas para 30 marcadores microssatélites posicionados nos cromossomos 3 e 5 para determinar o grau de informação dos marcadores. Os marcadores informativos foram empregados na genotipagem seletiva das aves F2 que apresentaram valores fenotípicos extremos (4,5\% superiores e 4,5\% inferiores), dentro de cada uma das 20 famílias, para a característica peso vivo aos 42 dias de idade ajustado (PV42aj). Os genótipos obtidos foram comparados através do teste de qui-quadrado. Foram encontradas seis regiões no cromossomo 3 e três regiões no cromossomos 5 com marcadores apresentando ligaçãio sugestiva $(P \leq 0,10)$ com $Q T L$ para PV42aj. Foram selecionadas seis famílias mais informativas para a maioria dos marcadores significativos, e 90 progênies F2 de cada família $(n=540)$ foram genotipadas. Os genótipos foram empregados para construção de mapas de ligação específicos 
para os cromossomos. Os fenótipos ajustados para efeitos fixos, os mapas de ligação e os genótipos foram empregados para mapeamento de QTL por análise de regressão, utilizando o programa QTL Express. Foram encontrados no cromossomo 310 QTL siginificativos para peso corporal aos 35, 41 e 42 dias de idade, para ganhos de peso do nascimento aos 35, 41 e 42 dias de id viii para peso de asas e coxas com sobrecoxas, e para peso de gordura abdominal e porcentagem de gordura. Foram observados um QTL no cromossomo $3 \mathrm{com}$ ligação sugestiva para peso de pés, e três QTL no cromossomo 5 para consumo de ração, peso do coração, peso de gordura abdominal e porcentagem de gordura abdominal. Não houve interações significativas do QTL com efeito de família ou sexo. Os QTL significativos para peso de gordura abdominal e porcentagem de gordura abdominal apresentaram forte efeito de imprinting gamético. Os efeitos dos QTL foram na sua maioria aditivos, com o alelo originado da linhagem de corte aumentando o valor para a característica. Características de carcaça apresentaram efeito aditivo negativo, indicando que os alelos provenientes da linhagem de postura diminuíram o valor dessas características. A população experimental foi adequada para o mapeamento de QTL significativos para características de desempenho e carcaça no cromossomo 3, e QTL sugestivos para características de carcaça no cromossomo 3 e características de desempenho e carcaça no cromossomo 5. 


\title{
MAPPING OF QUANTITATIVE TRAIT LOCI AFFECTING PERFORMANCE AND CARCASS TRAITS ON CHICKEN CHROMOSOMES 3 AND 5
}

\author{
Author: DEBORAH CLEA RUY \\ Adviser: Prof. Dr. LUIZ LEHMANN COUTINHO
}

\section{SUMMARY}

An $F_{2}$ chicken population was established from a cross of a broiler-sire line (TT) and an egg laying line (CC). This population was used for detecting and mapping quantitative trait loci (QTL). Over $2000 \mathrm{~F}_{2}$ TC offspring from 17 hatches were reared to slaughter at 6 wk of age. Twenty-eight performance and carcass traits were measured. The DNA were extracted from blood samples and informativeness of 50 selected microsatellite markers along chromosomes 3 and 5 were obtained in $F_{1} S$. Data of 2063 individuals from 20 families were used to chosen offspring with high and low phenotypes for BW42, for selective genotyping. Twenty markers were used in the complete genotyping of 566 individuals from 6 families most informative. Interval mapping QTL analyses were carried out by regression method, using QTL Express software. Significant QTL at the genome were mapped on chromosome 3 for body weigh at 35, 41 and 42 days, gain between birth and 35, 41 and 42 days, abdominal fat weight, abdominal fat percentage, weight of wings and weight of thighs. Suggestive QTL were identified for weight of feet on chromosome 3 and for abdominal fat weight, abdominal fat percentage, heart weight and feed consumption on chromosome 5. Significant QTL for abdominal fat weight and abdominal fat percentage 
showed strong imprinting effect. There was no evidence for interactions of the QTL with sex and family, or for two QTL on the same chromosome for any of the traits. Genetic effects were generally additive, with the broiler alleles increasing performance traits. Additive effects were negative for carcass traits, indicating that the layer line decreased these traits. Experimental population was adequate to mapping significant QTL for performance and carcass traits on chromosome 3 , and suggestive QTL for carcass traits on chromosome 3 and for performance and carcass traits on chromosome 5. 


\section{INTRODUÇÃO}

Dentre as atividades agropecuárias voltadas para a produção de alimentos, a avicultura ocupa lugar de destaque. Praticamente em todos os países que desenvolvem a avicultura moderna, a atividade tem alcançado altos índices de desempenho na produção de carne e ovos. No Brasil, esse agronegócio representa grande parte do nosso produto interno bruto; é responsável por grande parte do volume de dividendos obtidos com exportação de carne, às custas da eficiência de nossa cadeia produtiva, englobando fatores propícios de clima, custo de alimentação e mão de obra sensível para atender demandas diferenciadas do mercado externo. No ano de 2003 o país figurou como o segundo maior produtor e exportador mundial de carne de frango; o consumo interno foi atendido com $78 \%$ da produção, estimada em 7,82 milhões de toneladas. Desse total, foram exportadas 1,73 milhões de toneladas, trazendo 1,58 bilhões de dólares em dividendos; além disso, o setor avícola forneceu ao mercado interno aproximadamente 1,422 milhões de dúzias de ovos no mesmo ano (ANUALPEC, 2003).

A eficiência atingida na atividade avícola foi corroborada pelos dados apresentados por Havenstein et al. (1994) para frangos de corte, comparando o desempenho de aves de uma linhagem controle mantida a partir de 1957 sem pressão de seleção com uma linhagem empregada comercialmente em 1991 e constataram ganho em eficiência, resultando em diminuição no número de dias desde o nascimento da ave até o abate de um dia por ano, mantendo a tendência desse padrão. A evolução em desempenho produtivo e reprodutivo apresentada pelo frango (Gallus gallus) é baseada em seleção continuada de 
animais de valor genético superior. No processo seletivo, a observação de características herdadas e de clara expressão fenotípica permite classificar indivíduos, utilizando-se os melhores em acasalamentos dirigidos, visando obter progênies que podem dar continuidade à seleção ou encerrarem o ciclo como produto final.

De maneira geral, o melhoramento baseado na avaliação de expressões fenotípicas tem mostrado excelentes resultados. A acurácia na seleção é alta quando as características consideradas são regidas por poucos genes, de grande efeito, onde o ambiente tem influência relativamente pequena. Contudo, a maioria das características economicamente importantes em animais de produção tem herança quantitativa.

Características quantitativas são aquelas determinadas por muitos genes, cujos efeitos da maioria ou mesmo de todo o conjunto são pequenos, e sofrem forte influência do meio ambiente; em decorrência, indivíduos com um mesmo genótipo podem apresentar fenótipos totalmente distintos, enquanto indivíduos com genótipos diferentes podem sofrer ação do ambiente a ponto de seus fenótipos serem equivalentes. Considerando toda a complexidade do ambiente e a dificuldade de se controlar esse fator, não é possível inferir com certeza um genótipo a um animal, apenas pelo seu fenótipo.

O emprego de medidas de desempenho para estimar o valor genético de cada animal propiciou uma maior eficiência na seleção para características quantitativas. Valores genéticos estimados são calculados a partir de medidas em animais aparentados e são utilizadas para melhorar a seleção.

Contudo, determinados trabalhos de seleção têm evoluído de forma limitada, pois pode haver dificuldade nas mensurações e na conseqüente inferência de mérito genético para um animal que não expressa diretamente a característica, como por exemplo, seleção de machos visando a postura de ovos, avaliação da qualidade da carcaça sem que o abate possa ser efetuado, ou resistência a determinadas doenças sem que o próprio animal participe de um ensaio de desafio sanitário. Também características que demandam longo 
tempo para serem medidas ou que se expressam tardiamente, bem como aquelas de baixa herdabilidade, se mostram como entraves para uma seleção mais eficiente dos melhores animais (Kappes, 1999).

A biologia molecular é uma ferramenta atual que auxilia na evolução dos processos de seleção e de melhoramento animal, pois permite conhecer a variabilidade genética ao nível molecular. A possibilidade de se caracterizar os alelos paternos e maternos e relacioná-los com um fenótipo de interesse deu início ao conceito de marcadores. Estudos com plantas associando marcadores morfológicos com genes de importância econômica foram publicados nos anos 20; nas décadas de 50 e 60 foram publicados trabalhos utilizando enzimas, proteínas ou polimorfismos de grupos sanguíneos como marcadores genéticos para identificar genes afetando características quantitativas em animais (Bovenhuis et al., 1997). Contudo, a quantidade reduzida existente desse tipo de marcadores levou pesquisadores a buscar outros instrumentos para alcançar a mesma finalidade.

Atualmente, diferentes metodologias, derivadas do desenvolvimento nos anos 80 de tecnologias do DNA recombinante e da reação em cadeia da polimerase ("Polimerase Chain Reaction" - PCR), permitem a definição de marcadores moleculares distribuídos ao longo do genoma, possibilitando que muitos locos associados a características quantitativas tenham já sido identificados com sucesso em várias espécies.

O genoma do frango possui diversos marcadores já mapeados, em populações distintas. Groenen et al. (2000) relataram que, embora o primeiro mapa de ligação genético para frangos tenha sido publicado em 1936, mapas de ligação só foram gerados intensivamente nos anos 90, com a disponibilidade de grande número de marcadores moleculares. Os primeiros mapas para Gallus sp. baseados totalmente em marcadores de DNA utilizaram as populações referência Compton (C, Bumstead \& Palyga, 1992) e East Lansing (EL, Levin et al., 1993, 1994). Essas populações desenvolvidas por retrocruzamento continuaram a ser empregadas para mapear vários tipos de 
marcadores moleculares, porém seus tamanhos restritos (cerca de 50 descendentes em cada uma) limitam a resolução de mapeamento de marcadores espaçados muito próximos.

$\mathrm{Na}$ última década foi desenvolvida uma população-referência em delineamento de três gerações a partir do cruzamentoe entre duas linhagens de frangos de corte; foram identificados muitos marcadores microssatélites, muitos dos quais são adjacentes ou fazem parte de genes funcionais (Groenen et al.,1998). Uma vez que os mapas dessas três populações citadas apresentavam marcadores em comum, foi possível integrá-los em um mapa consenso com 50 grupos de ligação, um total de 1889 locos e uma cobertura mínima estimada de 3800 centiMorgans (cM) do genoma do frango, o que contraria as estimativas iniciais do tamanho desse genoma, de 2600 a $3000 \mathrm{cM}$ (Groenen et al.,2000).

O mapa consenso contém 801 marcadores microssatélites; esses marcadores também denominados repetições de seqüências simples atendem a maior parte das exigências requeridas para um bom marcador genético, tais como: estar distribuído ao longo do genoma para garantir que este possa ser mapeado em sua totalidade; ser bastante polimórfico; permitir ensaios rápidos, com clara interpretação genética, alta repetibilidade e fácil automação e, sobretudo, ser facilmente disseminados entre laboratórios. Portanto, microssatélites são os marcadores de escolha para trabalhos de varredura do genoma.

O genoma do frango tem características peculiares importantes, uma delas é seu tamanho, cerca de um terço daquele de mamíferos, devido à baixa quantidade de seqüências repetitivas e aos tamanhos reduzidos dos íntrons (Hughes \& Hughes, 1995). Mesmo possuindo apenas um décimo de seqüências repetidas em relação a mamíferos, ainda assim a quantidade de microssatélites já publicada é suficiente para permitir um rastreamento cuidadoso nos maiores cromossomos à procura de regiões ligadas a genes de 
interesse. Apenas os marcadores mapeados nos seis maiores cromossomos permitem cobrir cerca de $70 \%$ de todo o genoma (Soller et al., 1976).

Outra característica importante é o aparente alto nível de sintenia conservada entre os genomas do frango e de humanos, a despeito das estruturas genômicas bastante diferenciadas, o que o torna um modelo de evolução intermediária e possibilita o aproveitamento de informação adquirida no estudo do genoma humano sobre genes, permitindo que esses possam ser mapeados também nas aves.

A possibilidade de se obter um grande número de animais aparentados em espaço de tempo relativamente curto devido ao pequeno intervalo de gerações, aliada à alta prolificidade da espécie, favorecem o desenvolvimento de populações experimentais formadas a partir de cruzamentos controlados, permitindo que seja feita uma pesquisa intensa no genoma de frangos à procura de genes afetando características de herança poligênica, chamados de locos para características quantitativas ("Quantitative Trait Loci" - QTL).

Vários estudos de mapeamento no genoma do frango reportam a existência de QTL associados principalmente a desempenho, qualidade de carcaça - em especial relacionada ao teor de gordura e proporção de partes nobres - , qualidade do ovo e resistência a doenças, porém os resultados nem sempre apresentam a repetibilidade desejada em estudos posteriores. Dentre os cromossomos de grande tamanho, particularmente nos cromossomos 3 e 5 tem havido grande variabilidade em relação aos QTL mapeados.

Alguns aspectos que dificultam a repetição de resultados em estudos de mapeamento de QTL são as linhagens empregadas na formação de populações com as quais são desenvolvidas as pesquisas e o número muitas vezes reduzido de marcadores utilizados e de indivíduos genotipados. A escolha inadequada de níveis de significância adotados nos trabalhos prejudica a interpretação dos resultados (Lander \& Kruglyak, 1995). A própria aplicabilidade de QTL identificados em estudos empregando linhagens puras em linhagens comerciais também tem sido objeto de discussão (Hillel, 1997). 
Para que os QTL identificados possam ser validados, os trabalhos de pesquisa atuais devem empregar populações altamente divergentes, desenvolvidas quando possível a partir de linhagens comerciais; utilizar quantidades adequadas de marcadores e de indivíduos, para que haja eventos de recombinação suficientes que permitam a construção de mapas de ligação próprios e, através do uso de análises estatísticas apropriadas, seja mapeado um maior número de QTL.

A identificação de QTL para características de grande interesse comercial, em particular aquelas relacionadas a desempenho e qualidade de carcaça em aves, visa dar condições de, no futuro, fazer seleção assistida por marcadores ("Marker Assisted Selection" - MAS), a exemplo do que já ocorre com suínos. 


\section{REVISÃO DE LITERATURA}

\subsection{Caracterização do genoma da galinha (Gallus gallus)}

O cariótipo da galinha é composto de 38 pares de autossomos e dois cromossomos sexuais, $\mathrm{Z}$ e W, sendo a fêmea o sexo heterogamético (ZW) e o macho o homogamético (ZZ). Os cromossomos são diferenciados em dois grupos, nove macrocromossomos distinguíveis citogeneticamente e 30 microcromossomos, quase indistinguíveis uns dos outros (Crooijmans, 2000). O emprego da técnica FISH ("Fluorescence in situ Hybridization" - técnica de hibridização in situ fluorescente) permite o posicionamento de genes funcionais e marcadores de DNA em microcromossomos, facilitando sua distinção (Griffin et al., 2000 e Suzuki et al., 2000).

A despeito do grande número de cromossomos, na forma haplóide o genoma da galinha tem tamanho estimado de $1,2 \times 10^{9}$ pares de bases nitrogenadas $(\mathrm{pb})$, pequeno quando comparado ao tamanho do genoma de mamíferos, de aproximadamente $3 \times 10^{9} \mathrm{pb}$ (Crooijmans, 2000). Segundo Liu (1998), a relação entre distancia física, ou seja, milhares de bases nitrogenadas (kb) e distancia genética, medida em centiMorgans, varia de espécie para espécie, geralmente para um pequeno genoma a unidade de distancia genética possivelmente representa um pequeno segmento físico do genoma, enquanto para um genoma grande o segmento físico é proporcionalmente extenso.

A diferença nas estruturas de cariótipo de diferentes espécies pode ser compreendida se for considerado que a correlação entre distância física e distância entre genes ou locos varia também com a região cromossômica. 
Segundo Ferreira \& Grattapaglia (1998), existem regiões de apenas algumas dezenas de kb onde existe uma probabilidade de recombinação cromossômica alta relacionada a maiores distancias gênicas, e nesse mesmo organismo podem existir regiões de alguns milhares de kb onde a recombinação é praticamente suprimida, e a distância entre os genes presentes é mínima (por exemplo, nos telômeros e centrômeros).

Groenen et al. (2000), ao promoverem o ordenamento de locos mapeados em várias populações e posicioná-los em conjunto em um mapa consenso, concluíram que o genoma do frango tem tamanho aproximado de 3800 cM; esse valor permite estabelecer uma relação aproximada de 316 kb por centiMorgan, valor um pouco inferior aos $500 \mathrm{~kb}$ sugeridos por Levin et al. (1993) e por Crooijmans (2000). O genoma do frango equivale a um terço do genoma humano, pois este apresenta uma relação de $1000 \mathrm{~kb}$ para cada centiMorgan (Emara \& Kim, 2003). Não obstante, os mesmos autores afirmam que há grande conservação de grupos sintenicos entre aves e humanos.

O menor tamanho do genoma de aves é devido principalmente a um baixo número de seqüências repetitivas e a íntrons menores, comparativamente a mamíferos (Hughes \& Hughes, 1995). A pequena quantidade de seqüências repetitivas incide principalmente nos microcromossomos, o que tem dificultado o posicionamento de marcadores moleculares nesses segmentos. Primmer et al. (1997) analisaram a ocorrência, freqüência e distribuição de microssatélites em aves e concluíram que a densidade total dessas repetições em aves é de uma a cada 20-39 kb do genoma, muito mais baixa do que a densidade estimada para o genoma humano, de uma a cada 6-30 kb.

A escassez de repetições, particularmente de microssatélites, é compatível com a ocorrência de uma alta concentração de genes funcionais nesses microcromossomos (McQueen et al., 1998; Primmer et al., 1997 e Suzuki et al., 1999). Eventos de recombinação genética ocorrem em mais alta freqüência relativa à distância física nos microcromossomos do que nos macrocromossomos (Suzuki et al., 1999). 
A baixa densidade de microssatélites em todo o genoma do frango, em particular nos microcromossomos, impõe um obstáculo para o desenvolvimento de mapas genéticos ricos em marcadores cobrindo todo o genoma, o que conseqüentemente dificulta a localização precisa de genes afetando características quantitativas. Contudo, nos grandes cromossomos há uma densidade de marcadores já mapeados que se mostram em densidade suficiente para se proceder a uma busca confiável de QTL; com exceção de algumas regiões nesses cromossomos, os intervalos entre marcadores são em média de 20 cM (Groenen et al., 1998 e Zhu et al., 2001). Possivelmente a maior disponibilidade de marcadores está associada à identificação de QTL posicionados, em sua maioria, nos macrocromossomos (McElroy et al., 2002; Tatsuda \& Fujinaka, 2001; Van Kaam et al., 1998, 1999a e 1999b).

\subsection{Mapas genéticos e marcadores moleculares}

" Mapa genético de um animal ou planta pode ser definido como um modelo abstrato do arranjo linear de um grupo de genes e marcadores. O gene pode ser o tradicionalmente definido fator mendeliano ou um segmento de DNA identificado por função conhecida ou por meio de ensaio bioquímico. O marcador pode ser um "marcador" citológico, uma variante baseada na mudança em gene conhecido ou proteína, um segmento de DNA sem função conhecida ou mesmo um gene com função conhecida mas que contenha variação detectável. Ambos devem ter herança simples que possa ser acompanhada através de gerações" (Liu, 1998).

O mapeamento genético é fundamentado no desequilíbrio de ligação, na ligação gênica, nos eventos de recombinação e na função de mapeamento empregada. Falconer \& Mackay (1996) definem desequilíbrio de ligação como qualquer desvio das freqüências alélicas em relação as freqüências esperadas sob independência, indicando a existência de uma associação entre locos, passando em conjunto para a próxima geração. 
De acordo com Griffiths et al. (2002), quando ocorre associação entre dois genes ou marcadores localizados em um mesmo cromossomo, e suas proporções genotípicas esperadas após um determinado cruzamento afastamse das proporções mendelianas, supõe-se que esteja ocorrendo ligação gênica, isto é, alelos de genes ou marcadores situados no mesmo cromossomo tendem a ser herdados em conjunto.

Griffiths et al. (2002) definem recombinação como a produção de genótipos com novas combinações dos alelos parentais. Durante a meiose, ocorrem trocas de partes dos cromossomos parentais herdados no processo denominado "crossing-over"; o resultado dessa recombinação é o aparecimento de gametas recombinantes, a uma determinada freqüência, chamada de freqüência ou taxa de recombinação; as freqüências de recombinação representam as medidas de distância entre dois locos ao longo de um cromossomo, permitindo que esses locos sejam alinhados em um mapa genético (Lynch \& Walsh, 1998).

A construção de um mapa genético portanto envolve o ordenamento de locos e a medida da distancia entre eles. Em 1910 Stutervant postulou que, quanto maior a distancia entre os genes ligados, maior a chance de que as cromátides não-irmãs façam "crossing-over" na região entre os genes e assim maior a proporção de recombinantes que seriam produzidos (Griffiths et al., 2002).

As freqüências de recombinação porém não são aditivas, e a recombinação em um loco pode causar interferência em locos próximos (Liu, 1998). Foram desenvolvidas funções de mapeamento apropriadas que relacionam medidas de distância genética entre dois locos (em cM) com a taxa de recombinantes; utiliza-se como medida a unidade Morgan (M), ou mais comumente, o centiMorgan (cM). Varias funções de mapeamento distintas foram equacionadas, as mais empregadas nos mapas genéticos para animais e plantas são as funções de Haldane e Kosambi, esta última considerando alguma interferência (Griffiths et al., 2002, Lynch \& Walsh,1998 e Liu, 1998). 
O mapeamento genético requer então a presença de polimorfismos detectáveis, os chamados marcadores, que estejam em recombinação ou segregação em uma determinada população. Os marcadores genéticos clássicos, inicialmente empregados, limitavam-se a polimorfismos físicos, grupamentos sanguíneos e diferentes isoenzimas. Entretanto, marcadores genéticos clássicos são determinados na prática em nível bastante limitado.

Dodgson et al. (1997) afirmaram que o atraso no desenvolvimento de um mapa de ligação consenso para frangos se deveu ao número insuficiente de polimorfismos disponíveis, e o alto custo na geração de indivíduos cujo genoma possuísse amplo número de marcadores detectados, permitindo que a segregação de diversos locos pudesse ser acompanhada em apenas uma família. De acordo com Ferreira \& Grattapaglia (1998), o pequeno número de marcadores morfológicos em uma mesma linhagem reduziria a probabilidade de serem encontradas associações significativas entre esses marcadores e caracteres de importância econômica através do estudo de populações segregantes.

A evolução de ensaios baseados no DNA permitiu medir a herança de diferenças de até um único par de bases entre cromossomos homólogos. Considerando-se que o nível padrão de diferença no DNA entre indivíduos não endogâmicos ("outbred") de uma mesma espécie é da ordem de uma mudança a cada $1 \mathrm{~kb}$, e se for considerado que é possível detectar com precisão esse polimorfismo, então teoricamente a densidade de marcadores disponíveis em qualquer cruzamento é enorme, considerando-se uma resolução teórica de cerca de 0,002 cM no genoma de frango, conforme relação de $1 \mathrm{cM}$ para cada $500 \mathrm{~kb}$ sugerida por Levin et al. (1993).

Diferentes marcadores do DNA passaram a serem obtidos a partir da evolução da tecnologia aplicada a estudos de genética, merecendo destaque as técnicas de eletroforese de isoenzimas, clonagem, uso de enzimas de restrição e refinamento da técnica de PCR, aliadas à automação das análises de DNA, agilizando o processamento de grande número de amostras. Os marcadores 
moleculares apresentam algumas vantagens em relação aos marcadores morfológicos, tais como: níveis de polimorfismo geralmente altos para cada loco estudado, em geral são codominantes, contendo maior quantidade de informação genética por loco (Ferreira \& Grattapaglia, 1998). Dentre os diversos tipos de marcadores moleculares, alguns se mostram mais eficientes em relação a outros, principalmente sob o aspecto de repetibilidade entre indivíduos avaliados e em diferentes laboratórios, ou em relação à característica de dominância, que dificulta o estudo em determinadas estruturas populacionais.

Os marcadores do DNA podem ser divididos em dois grupos: (1) marcadores tipo I, associados a genes de funções conhecidas, e (2) marcadores tipo II, associados com segmentos não-codificantes ou genes anônimos (Dodgson et al., 1997). Groenen et al. (2000) publicaram um mapa de ligação consenso para Gallus sp., posicionando 235 marcadores representando genes já identificados ou seqüências mostrando significante identidade com seqüências de genes conhecidos, sendo que 204 foram ortólogos a genes mapeados no genoma de humanos. Segundo Cheng (1997), a razão primária para o pequeno número de marcadores tipo I mapeados é que genes mostram maior conservação de seqüência quando comparados a regiões não codificantes, conseqüentemente genes exibem menos polimorfismos que possam ser mapeados ou utilizados em pesquisas de busca de QTL.

Marcadores moleculares tipo I localizados no genoma da galinha são em quantidade pequena quando comparada àquela já definida para genomas mais estudados, tais como o de humanos e o do camundongo, dificultando até certo ponto o mapeamento comparativo entre espécies. Atualmente há uma grande quantidade de marcadores tipo II posicionados em mapas de ligação de populações experimentais de frangos e em um mapa consenso; esses marcadores apresentam maior polimorfismo, são obtidos em sua maioria a partir de regiões não codificantes, e compreendem a maioria dos marcadores mapeados (Groenen et al., 2000). 
Alternativamente, Dodgson et al. (1997) classificaram os marcadores moleculares em: (1) marcadores clonados/seqüenciados e (2) marcadores "fingerprint", os quais não requerem conhecimento a priori da seqüência da região polimórfica ou isolamento de um fragmento de DNA clonado. À primeira categoria pertencem RFLP ("Restriction Fragment Length Polymorphism"), microssatélites ou repetições de seqüências simples ("Simple Sequence Repeat" - SSR) e EST ("Expressed Sequence Tag"), empregados para determinação de mapas de ligação; requerem o isolamento de fragmentos de DNA clonado e, freqüentemente, o seqüenciamento completo ou parcial desse DNA. Os marcadores incluídos na segunda categoria não requerem conhecimento prévio da seqüência da região polimórfica ou isolamento de fragmento de DNA clonado; são utilizados AFLP ("Amplified Fragment Length Polymorphism"), RAPD ("Random Amplified Polymorphic DNA"), CR1(“Chicken repeat 1-based marker") e minissatélites para criar mapas de ligação. Os marcadores "fingerprint" são todos marcadores tipo I, enquanto os obtidos por clonagem / seqüenciamento incluem tanto marcadores tipo I quanto tipo II.

O desenvolvimento dos diferentes tipos de marcadores de DNA e seu posicionamento em mapas de ligação de aves deu impulso às pesquisas de identificação de QTL, porém a opção pelo uso de cada um difere, pois cada categoria apresenta vantagens e desvantagens: facilidade e custo de obtenção, repetibilidade, conveniência dependendo da estrutura populacional, entre outras. Groenen et al. (2000) relacionaram os marcadores empregados nos mapas de ligação de três populações-referência, bem como aqueles posicionados em um mapa consenso obtido a partir desses mapas de ligação, sendo que microssatélites, AFLP e RFLP representavam de $74 \%$ até a totalidade dos marcadores posicionados nesses mapas.

A maior parte dos marcadores moleculares empregados inicialmente para obter o primeiro mapa de ligação publicado para aves (população Compton) foram RFLPs (Bumstead \& Palyga, 1992). Após três anos de sua publicação, RFLPs representavam cerca de 14\% (87 marcadores) dos 617 
marcadores dispostos no segundo mapa de ligação da população East Lansing, publicada por Levin et al. (1993, 1994). RFLP são obtidos a partir de um simples polimorfismo dentro da seqüência de um sítio de restrição ou de inserções ou deleções ocorrendo dentro de um fragmento de restrição, requerendo DNA clonado mas não seu seqüenciamento. Esse tipo de marcador é codominante, isto é, em cada loco estudado é possível identificar genótipos heterozigotos e homozigotos, cobre praticamente todo o genoma, relativamente barato e fácil de ser gerado e seu número é praticamente ilimitado (Ferreira \& Grattapaglia, 1998). As principais desvantagens são ter os estágios de desenvolvimento e de tipificação bastante laboriosos e serem na sua maioria bialélicos, o que implica em menor polimorfismo do que os microssatélites, por exemplo, motivo pelo qual sua detecção tem sido descontinuada em projetos de mapeamento em animais (Cheng, 1997 e Dodgson et al., 1997).

Microssatélites, também denominados SSR, são repetições agrupadas de 1 a 6 pb, dispersos no genoma animal. A forma mais comum é a repetição de dinucleotídios; repetições de tri e tretranucleotídios também são observadas, mas em freqüências mais baixas (Liu, 1998). Têm como vantagens serem multialélicos, altamente polimórficos, codominantes e obtidos por PCR (Dodgson et al., 1997 e Ferreira \& Grattapaglia, 1998). Têm como desvantagem o elevado custo inicial de formação de "primers" flanqueando as regiões repetitivas e o custo dos equipamentos para automação das análises de genotipagem; contudo, essa possibilidade de automação e a alta probabilidade de encontrar polimorfismo no DNA fazem dos microssatélites os marcadores de eleição para mapeamento e procura de QTL por todo o genoma (Cheng, 1997 e Dodgson et al., 1997). Um terceiro mapa de ligação publicado empregou microssatélites como seus principais marcadores (Groenen et al., 1998); trabalhos mais recentes relatam 0 posicionamento de marcadores microssatélites nas populações $C$ e EL e já são a maioria dos marcadores posicionados também para estas famílias (Cheng et al., 1995; Crooijmans et al., 1997; Gibbs et al., 1997 e Groenen et al., 2000). 
Marcadores AFLP foram mapeados por último nos mapas de ligação existentes. Sua obtenção requer clivagem do DNA com enzimas de restrição, amplificação por PCR de parte do fragmento gerado com "primers" especificamente desenhados e posterior separação dos fragmentos amplificados em gel de alta resolução (Ferreira \& Grattapaglia, 1998).

Merece menção o uso de marcadores RAPD, uma vez que seu custo de obtenção é relativamente baixo; foram empregados em vários estudos de mapeamento (Cheng et al., 1995; Levin et al., 1993). RAPD são fragmentos de DNA polimórficos, produzidos em reação de PCR utilizando "primers" oligonucleotídios de 10 bases; existem no genoma sítios complementares perfeitos e imperfeitos, de forma que muitas regiões de 5000 pb ou menores podem ser amplificadas, gerando polimorfismo (Cheng, 1997). São marcadores dominantes, permitindo a detecção da presença ou ausência do alelo, não distinguindo indivíduos heterozigotos de homozigotos. Por serem dominantes, não são recomendados para análises de populações com delineamento F2 tradicional, pois possuem baixo conteúdo de informação de ligação (Liu, 1998). No entanto RAPDs foram mapeados sem restrições para a população EL, por tratar-se de um delineamento de retrocruzamento (Levin et al., 1993 e 1994).

Essa propriedade de dominância faz com que os RAPD sejam aplicados facilmente para mapeamento dos cromossomos sexuais, permanecendo como o marcador predominante no mapa para o cromossomo $Z$ de frango (Levin et al., 1993 e Dodgson et al., 1997). Sua maior desvantagem é a dependência das condições exatas de PCR empregadas para obtenção dos padrões de RAPD, dificultando a reprodutibilidade entre ensaios e entre laboratórios.

Novos marcadores continuam a ser identificados, concomitantemente a novas pesquisas visando validar o posicionamento de QTL já mapeados e fazer o rastreamento de novos QTL em populações-referência já existentes e em novas populações experimentais desenvolvidas por outros grupos de pesquisa. A seleção dos marcadores mais adequados para criação de mapas de ligação e localização de QTL deve considerar a disponibilidade dos próprios marcadores, 
de equipamentos adequados para automação na determinação de polimorfismos e no grau de polimorfismo esperado de cada marcador para uma determinada população.

Atualmente uma terceira geração de mapeamento genético conduzida em humanos usa SNPs ("Single Nucleotide Polymorphisms"); uma vantagem dos SNPs é que eles geralmente estão ligados ao gene de interesse, permitindo que a associação do SNP com características de importância econômica possam ser analisadas usando uma abordagem de genes candidatos. Com os avanços na caracterização de ESTs em frangos, a identificação de polimorfismos do tipo SNP em genes de frangos já é uma realidade (Emara \& Kim, 2003).

\subsection{QTL e fatores que afetam sua ligação com marcador}

As regiões genômicas associadas com a expressão de características quantitativas denominadas QTL ("Quantitative Trait Loci”) são detectáveis quando esses QTL estão em desequilíbrio de ligação com um marcador genético. Desequilíbrio de ligação é qualquer desvio das freqüências alélicas em relação às freqüências esperadas sob independência, indicando a existência de uma associação entre locos, ou no caso, entre marcadores e QTL. Mackay (2001) afirmou que, se um QTL está ligado a um loco marcador, haverá uma diferença nos valores médios da característica quantitativa entre indivíduos com diferentes genótipos no loco marcador.

Para a identificação de QTL em populações experimentais ser bem sucedida, devem ser atendidas inicialmente duas premissas: (1) existência de marcadores informativos e (2) escolha de uma estrutura populacional adequada em que haja variação genética suficiente para detectar ligação entre um QTL segregando e um marcador genético (Deeb \& Lamont, 2002). De acordo com Hillel (1997), quando uma característica tem um padrão de herança poligênico, 
como é o caso da maioria daquelas controladas por QTL, é preciso garantir suficiente variação genética na população experimental.

Uma maneira de se introduzir desequilíbrio de ligação em uma população é pelo cruzamento de linhagens que diferem em relação às suas freqüências alélicas nos locos do marcador e do QTL, ou seja, a escolha das linhagens parentais via de regra é feita pela divergência existente entre elas em relação à característica sob estudo; assim, as associações presentes entre marcadores genéticos e a característica podem ser estudadas comparando-se o desempenho fenotípico de indivíduos F2 ou obtidos por retrocruzamento (Bovenhuis et al., 1997 e Yonash et al., 2001).

As linhagens parentais empregadas nesses delineamentos populacionais podem ser endogâmicas ou não-endogâmicas. Assume-se que linhas endogâmicas estão fixadas para alelos alternativos tanto para o marcador quanto para o QTL; isso implica em todos os indivíduos F1 serem heterozigotos para o marcador e o QTL, que haja somente dois alelos tanto para marcador quanto para o QTL e que todos os indivíduos F1 tenham a mesma fase de ligação (Bovenhuis et al., 1997). Linhagens endogâmicas estão disponíveis e são amplamente utilizadas em experimentos com plantas e em muitos experimentos com animais de laboratório (Moody et al., 1999). A endogamia também pode ser obtida em animais de interesse zootécnico, tais como frangos e suínos. Há vários experimentos publicados empregando populações experimentais obtidas a partir de cruzamento entre linhagens endogâmicas divergentes, com delineamento F2 ou retrocruzamento, nas quais foram localizados QTL: a população de aves EL, elaborada com o objetivo de mapear marcadores moleculares, foi desenvolvida a partir do cruzamento de uma linhagem (JF) parcialmente endogâmica com outra (WL) altamente endogâmica (Crittenden et al., 1993).

Populações não endogâmicas submetidas a vários ciclos de seleção são comumente empregadas, contudo há desvantagens em se usar essas populações para mapeamento de QTL. Zhu et al. (2001) apontaram algumas 
limitações no uso dessas populações não-endogâmicas: (1) locos afetando características sob seleção podem estar a freqüências extremas ou fixados nas populações, o que reduz muito o conteúdo de informação dos marcadores e QTL; além disso, populações selecionadas podem ter diminuídas as diferenças fenotípicas, porque alelos com efeitos indesejáveis estão provavelmente reduzidos ou eliminados após longo tempo de seleção; (2) as fases de ligação entre QTL e marcadores de DNA podem variar entre as famílias, então a associação entre QTL e marcadores deve ser analisada separadamente para cada família e (3) a análise estatística é mais laboriosa porque até quatro alelos podem estar segregando em cada loco do QTL e do marcador molecular dentro de uma família.

As desvantagens apontadas podem significar redução no poder de detecção de QTL, mas mesmo assim o mapeamento de QTL em populações não-endogâmicas não pode ser completamente substituído por populações endogâmicas, pois nestas a detecção de QTL é geralmente baseada em diferenças fixadas entre linhagens, e sua relevância para QTL segregando dentro de populações não-endogâmicas não é clara; sob o ponto de vista prático, tal como MAS, os QTL detectados em cruzamentos entre linhagens endogâmicas podem não estar segregando em populações comerciais atendendo o mercado atualmente (Zhu et al., 2001).

Segundo Hillel (1997), a população experimental ideal deveria incluir os polimorfismos existentes já conhecidos em linhagens comerciais. Uma população experimental simplesmente baseada em cruzamentos entre populações geneticamente distantes irá mostrar sem dúvida um alto nível de variação genética, aumentando a possibilidade de se detectar ligações entre marcadores e QTL; entretanto há freqüentemente desacordo quanto à aplicabilidade da informação genética obtida de populações distantemente relacionadas, por exemplo, uma linhagem comercial, com um QTL fixado, pode não se beneficiar com um QTL polimórfico em uma população distante e viceversa, que está em concordância com Zhu et al. (2001). 
Van Kaam et al. (1998, 1999a e 1999b) empregaram em vários experimentos a população-referência WAU, concebida a partir do cruzamento de duas linhagens comerciais divergentes de frango de corte, com o objetivo de detectar e posicionar QTL para desempenho e características de carcaça; suas pesquisas foram as primeiras a utilizar um grande número de animais F3 e de marcadores microssatélites genotipados.

Tatsuda \& Fujinaka (2001) desenvolveram uma população F2 para mapeamento de QTL para ganho de peso a partir de uma raça nativa (SD) com baixo ganho de peso com uma linhagem selecionada (WR) para alto ganho de peso, com o propósito inicial de melhorar as taxas de crescimento de uma raça comercial, obtida por vários ciclos de seleção na formação da qual participou a linhagem WR e, na origem, a raça nativa SD. McElroy et al. (2002) também utilizaram o conceito de Hillel, empregando machos e fêmeas de duas linhagens comerciais de frangos de corte em cruzamentos recíprocos em um delineamento F2, para testar a ligação de marcadores moleculares com QTL para crescimento e características de carcaça.

O tamanho da população avaliada e o número de marcadores utilizados são fatores relevantes para se obter ligação verdadeira entre o marcador e o QTL. Poucos marcadores e esparsamente distribuídos diminuem as chances de se encontrar desequilíbrio de ligação entre marcador e QTL. Muitos marcadores genotipados, se avaliados estatisticamente sob baixa estringência, podem levar a mais falsas ligações com QTL. Contudo, segundo Hillel (1997), quanto mais marcadores regularmente espaçados forem utilizados na busca de QTL, maior a probabilidade de se identificarem ligações verdadeiras.

Em ensaio comparando aspectos relativos à resposta imunológica, Yonash et al. (2001) avaliaram uma população desenvolvida a partir de linhagens de frangos de corte escolhidas pela baixa ou alta resposta de anticorpos à Escherichia coli; foram genotipadas 83 progênies F2 e 77 progênies retrocruzadas para 25 microssatélites cobrindo aproximadamente $25 \%$ do genoma, conferindo uma cobertura de $20 \mathrm{cM}$ de cada lado do 
marcador, com sobreposição entre eles; três associações significativas de marcadores com resposta imune foram identificadas. Esses resultados são satisfatórios considerando-se a quantidade de animais genotipados e o número total de marcadores.

Van Kaam et al. (1998) conduziram pesquisa visando identificar QTL para peso corporal aos 48 dias utilizando a população WAU; foram genotipados 20 animais da geração 1 e 451 animais da geração 2, enquanto o fenótipo para análise empregou dados de 2049 indivíduos da geração 3. No entanto, nesse experimento foi possível identificar apenas um QTL, mesmo genotipando 368 marcadores microssatélites, cobrindo 24 grupos de ligação, com distância média entre marcadores de $8,5 \mathrm{cM}$.

Outro estudo foi conduzido por Van Kaam et al. (1999a) empregando a mesma população-referência WAU para localização de QTL afetando crescimento e eficiência alimentar; os animais foram genotipados para 420 microssatélites distribuídos em 27 grupos de ligação, sendo detectados um QTL significativo e três QTL sugestivos, porém não houve ligação significativa para peso corporal aos 23 dias nem aos 48 dias de idade, a despeito do número elevado de marcadores, da alta herdabilidade dessa característica e do tamanho suficientemente grande da população.

Conforme observado por Yonash et al. (2001) e Deeb \& Lamont (2002), na população WAU ambas as linhagens parentais foram similarmente selecionadas para alto peso corporal, então a população derivada de seu cruzamento aparentemente não segregou para QTL único com um efeito principal significante para essa característica.

Há vários fatores que afetam o poder de detecção para o mapeamento de QTL, alguns controláveis e outros não. Dentre os fatores controláveis estão os já mencionados previamente, ou seja, tipo e tamanho da amostra, que pode ser manipulada para aumentar o poder de detecção do QTL. Segundo Lander \& Botstein (1989), experimentos com maior tamanho de amostra podem detectar locos de menores efeitos genéticos do que aqueles com menor tamanho de 
amostra; essa orientação tem sido seguida nos estudos mais recentes de mapeamento de QTL.

Dentre os fatores não controláveis estão aqueles associados às características sob estudo, tais como o número e a localização dos genes associados a elas e a distribuição dos efeitos desses genes e suas interações, bem como a própria herdabilidade da característica; para contornar estes fatores novas metodologias estatísticas estão sendo rotineiramente desenvolvidas, associadas com densidade adequada do mapa de ligação (Zhu et al. 2001).

Para ser obter marcadores suficientes em número e informação que permitam conferir sua ligação com o QTL é preciso considerar um número inicial maior de marcadores no experimento, pois nem todos serão informativos. Teoricamente, uma grande família de irmãos completos que fosse totalmente informativa, com todos os alelos parentais distinguíveis em todos os locos seria suficiente para mapeamento de QTL, mas essa família provavelmente não existe em nenhuma população (Zhu et al., 2001). Um grande número de famílias poderia aumentar as chances de se ter ao menos um casal informativo em cada loco; adicionalmente, aumentar o tamanho das famílias irá criar mais poder de detecção de QTL do que aumentar o número de famílias (Van der Beek et al., 1995).

Conforme discorreram Zhu et al. (2001), "O conhecimento do conteúdo de informação de polimorfismo ("Polymorphism Information Content" - PIC), ou seja, a probabilidade de que um parental seja heterozigoto no loco do marcador e que o outro parental tenha um genótipo diferente em populações teste, seria muito útil para se determinar o número de famílias e o tamanho das famílias para o estudo de mapeamento de QTL". O estudo de Zhu et al. (2001) encontrou valor de PIC de 0,45 para as duas linhagens de frango de corte empregadas. Tuiskula-Haavisto et al. (2002), empregando linhagens de postura, encontraram valor de PIC médio para os marcadores utilizados de 
0,58; essa diferença em conteúdo de polimorfismo é esperada entre linhagens de corte e de postura.

Em populações não endogâmicas, onde o genótipo dos parentais é variável, as famílias a serem genotipadas podem ser escolhidas baseando-se na heterozigozidade dos marcadores nos parentais ou na geração F1, para se obter maior informatividade dos marcadores. Hillel (1997) propôs seis categorias para distingüir o conteúdo de informação para um casal F1 através das quais podem ser escolhidas as famílias e suas progênies $F 2$, sendo a categoria A representada por ambos machos e fêmeas F1 heterozigotos com nenhum ou apenas um alelo em comum, considerados altamente informativos, e a categoria $E$ representada por macho e fêmea F1 homozigotos para os mesmos alelos, não informativos.

A determinação da informação contida em cada loco bem como o grau de polimorfismo do marcador permite o descarte de marcadores inadequados. Segundo Crooijmans et al. (1996), o polimorfismo para locos de marcadores microssatélites em aves é relativamente baixo se comparado a suínos e bovinos; esses autores, avaliando linhagens comerciais de frangos de corte, obtiveram heterozigozidade estimada de $53 \%$ e observaram em média 3,6 alelos por loco do marcador, valor bastante similar ao observado em estudo publicado por Zhu et al. (2001) avaliando 25 machos F1, onde foi obtida heterozigozidade de 58,5\%, empregando linhagens de frango de corte distintas como parentais, e foram detectados 3,3 e 3,4 alelos por loco do marcador nas linhagens de corte dos parentais machos e fêmeas, respectivamente, mesmo tendo sido empregados marcadores diferentes dos utilizados no experimento de Crooijmans et al. (1996).

Moody et al. (1999), em estudo com camundongos para identificar QTL influenciando o balanço energético, selecionaram para a genotipagem os marcadores totalmente informativos, identificando aqueles que possuíam alelos distintos nas linhagens endogâmicas parentais. Tatsuda \& Fujinaka (2001) empregaram uma população experimental F2 de frangos, obtida pelo 
cruzamento da raça SD de baixo ganho de peso com a linhagem WR de alto ganho de peso, para mapeamento de QTL afetando peso corporal; inicialmente 331 primers de marcadores microssatélites foram utilizados, dos quais 78 foram selecionados pela facilidade de amplificação e informatividade.

Em experimento para detecção de QTL afetando resposta imunológica em frangos de corte, Yonash et al. (2001) genotiparam inicialmente 61 marcadores para o macho selecionando apenas os informativos, que posteriormente foram genotipados nas fêmeas, resultando em 25 marcadores informativos genotipados na progênie.

A escolha de marcadores moleculares informativos evita que marcadores não polimórficos ou famílias não informativas sejam genotipados, reduzindo sobremaneira os custos implicados em todo o processo de genotipagem.

\subsection{Genotipagem seletiva}

O poder de detecção da ligação marcador-QTL está diretamente relacionado com o número de indivíduos genotipados em uma população. Considerando que a genotipagem de grande número de indivíduos para todos os marcadores informativos é bastante dispendiosa, a opção por tipificar uma amostra populacional considerada viável faz com que o poder de detecção obtido seja freqüentemente baixo. Os QTL que podem ser detectados nessa situação são somente aqueles explicando individualmente mais do que $10 \%$ da variância (Muranty et al., 1997); além disso, a precisão da localização do QTL e a estimativa do seu efeito são baixas. QTL com pequenos efeitos, explicando 1 \% ou menos da variância, podem ser detectados somente com milhares de indivíduos genotipados na população segregante (Muranty \& Goffinet, 1997).

A genotipagem seletiva é um método para se aumentar o poder de detecção de QTL e para melhorar a precisão com médias constantes. Este método consiste em genotipar somente os indivíduos da cauda superior e inferior da curva de distribuição normal dos valores fenotípicos da amostra 
completa de uma população (Lander \& Botstein, 1989; Darvasi \& Soller, 1992; Muranty et al., 1997); dessa maneira o número de indivíduos genotipados para um dado poder de detecção pode ser reduzido consideravelmente, às expensas de um aumento no número de animais fenotipados.

Segundo Lander \& Botstein (1989), em uma população experimental uma parte da progênie contribui com mais informação para determinar a ligação entre marcador molecular e QTL do que a parte restante. Indivíduos com fenótipos extremos são, na sua maioria, aqueles que possuem em seu genótipo os alelos mais favoráveis ou desfavoráveis para a característica avaliada; os indivíduos posicionados próximos da média fenotípica da população contribuem com pouca ou nenhuma informação. Os autores ainda afirmam que, em uma distribuição normal para determinada característica quantitativa, progênies com valores fenotípicos de mais de um desvio-padrão em relação à média representam aproximadamente $33 \%$ da população total e contribuem com cerca de $81 \%$ de toda a informação de ligação do marcador com QTL.

Se for considerada uma população formada por linhagens endogâmicas, a curva de distribuição normal para uma característica fenotípica da progênie F2 terá possivelmente nos extremos os indivíduos homozigotos para alelos alternativos, e o contraste esperado para o respectivo marcador é máximo nesta situação, o que aumenta o poder do experimento (Bovenhuis \& Spelman, 2000).

A proporção ótima de seleção depende dos custos de genotipagem em relação aos custos de crescimento e mensuração de um indivíduo; se a proporção ótima estimada de genotipagens fosse de $25 \%$, isso implicaria em uma quantidade quatro vezes maior de indivíduos fenotipicamente avaliados em relação aos genotipados. Para obter a mesma eficiência na detecção de QTL afetando a característica sob seleção sem a genotipagem seletiva, uma população 2,9 vezes maior do que a quantidade de indivíduos genotipados no exemplo acima descrito, deveria ser desenvolvida, mensurada e genotipada (Muranty \& Goffinet, 1997). 
A relação de custo que determina a proporção ótima selecionada foi denominada C por Darvasi \& Soller (1992); segundo os autores, um valor de C deveria variar apropriadamente entre 1 e 10 quando se considerassem experimentos com propósito de mapeamento de QTL feitos com árvores frutíferas, grandes animais ou características onerosas para se medir; nesses casos a seleção ótima seria entre 10 e 40\%. Em contraste, a relação $C$ pode ser muito grande para características que são prontamente medidas em plantas anuais ou em pequenos animais, tal como peso corporal em frangos; nesses casos a seleção ótima para a genotipagem estaria em uma amplitude entre 5 e $10 \%$.

A genotipagem seletiva também pode ser aplicada a populações não endogâmicas, contudo a seleção deve ser aplicada dentro de famílias (Bovenhuis \& Spelman, 2000). Em populações não endogâmicas os marcadores e QTL possivelmente não segregam igualmente em todas as famílias. Muranty et al. (1997) afirmaram que o valor quantitativo de cada indivíduo é o resultado de um efeito de família, que pode ser separado em alguns casos em efeitos geral e de habilidade de combinação específica, efeito de genótipo dentro de família e efeito ambiental. Se os indivíduos forem escolhidos nos extremos da população, todos os indivíduos de algumas famílias poderiam ser escolhidos e indivíduos de algumas outras famílias poderiam não ser escolhidos, justamente pelo efeito de família. Conseqüentemente, para aplicar genotipagem seletiva em indivíduos não endogâmicos, eles devem ser escolhidos nos extremos dentro de cada família.

Freqüentemente a genotipagem seletiva tem sido aplicada em experimentos avaliando uma única característica. Contudo, em estudos de mapeamento de QTL para desempenho, o interesse normalmente recai sobre múltiplas características. Uma possibilidade seria aplicar a genotipagem seletiva para cada característica de interesse, contudo o benefício de menos genotipagens diminuiria à medida que o número de características aumentasse. 
Uma outra alternativa é fazer a genotipagem seletiva de indivíduos nas caudas de uma curva fenotípica para uma característica de eleição, tal como a de maior interesse em um programa de melhoramento ou a característica de menor herdabilidade, investigando nos mesmos indivíduos se há ligação entre marcadores e QTL também para outras características correlacionadas (Bovenhuis \& Spelman, 2000; Muranty et al., 1997 e Muranty \& Goffinet, 1997).

Bovenhuis \& Spelman (2000) avaliaram as conseqüências do método para características correlacionadas em populações não endogâmicas através de simulação e derivaram fórmulas possibilitando a obtenção de estimativas não tendenciosas dos efeitos de QTL tanto para a característica principal escolhida para a genotipagem seletiva quanto para as correlacionadas; segundo os autores as fórmulas apresentadas indicaram que o poder de se detectar um QTL afetando uma característica correlacionada é ao menos tão grande quanto se a genotipagem fosse feita ao acaso, mas que o poder de detecção é consideravelmente reduzido para detectar QTL para outras características com correlação próxima de zero em relação à escolhida.

Essas conclusões estão em parcial concordância com estudo prévio de Muranty \& Goffinet (1997), que propuseram fórmulas para se obter precisão nas estimativas de efeito e localização de QTL e demonstraram que a genotipagem seletiva aumentou a eficiência de detecção de QTL tanto para a característica principal quanto para as correlacionadas; apenas para as características não correlacionadas a acurácia na detecção foi semelhante a uma seleção feita ao acaso.

Lander \& Botstein (1989) observaram que programas computacionais calculando regressão linear normalmente utilizados no mapeamento de QTL não poderiam ser utilizados quando somente a progênie de fenótipo extremo fosse genotipada, pois os efeitos fenotípicos poderiam ser grosseiramente subestimados devido à seleção tendenciosa da progênie. Esses autores afirmaram que o método de mapeamento de QTL proposto por eles nesse trabalho -mapeamento por intervalo- era adequado, pois empregava todos os 
fenótipos, considerando os genótipos não extremos como dados perdidos. Como mencionado anteriormente, Muranty \& Goffinet (1997) e Bovenhuis \& Spelman (2000) propuseram o emprego de fórmulas para tornar o cálculo do efeito do QTL não tendencioso, para populações endogâmicas e não endogâmicas, respectivamente.

Alternativamente, a genotipagem seletiva pode ser utilizada como um ensaio prévio para detectar QTL, sem o emprego de fórmulas de ajuste de seus efeitos. A aplicação de testes estatísticos que permitam associar diferenças fenotípicas aos genótipos obtidos seletivamente indicaria os marcadores ligados a QTL. Posteriormente, mais animais podem ser genotipados para esses marcadores e para outros adjacentes e submetidos à nova análise estatítica (Hain et al., 2000, Kirkpatrick et al., 1998 e Moody et al., 1999). Uma análise estatística utilizando a totalidade dos dados daria uma maior precisão na localização dos QTL, sem que houvesse tendenciosidade no cálculo de seus efeitos, esperada com os dados da genotipagem seletiva apenas.

Vallejo et al. (1998), investigando a presença de QTL afetando susceptibilidade à doença de Marek, fizeram genotipagem seletiva em 80 indivíduos F2 de um total de 272 progênies, correspondendo aos valores fenotípicos superior e inferior da distribuição normal de três parâmetros avaliados; foram feitas associações simples entre os genótipos dessas progênies F2 para cada loco dos 65 marcadores testados distribuídos ao longo de todo o genoma e valores fenotípicos de susceptibilidade à doença de Marek utilizando análise de variância, sendo considerados sugestivos de regiões potenciais com QTL os locos de marcadores cujos testes $F$ produziram valores de $P \leq 0,20$. Em um segundo estágio, os marcadores sugestivos e outros marcadores adicionais disponíveis flanqueando essas regiões foram genotipados para os 272 animais F2.

Yonash et al. (2001) identificaram QTL afetando resposta imunológica em frangos de corte, utilizando inicialmente 25 marcadores microssatélites informativos cobrindo cerca de $800 \mathrm{cM}$ para genotipar $40 \%$ da população 
experimental, soma dos $20 \%$ de indivíduos com maior resposta de anticorpos à inoculação com Escherichia coli e os $20 \%$ com menor resposta; foram descartados para a genotipagem posterior de toda a população F2 e retrocruzada os marcadores que não indicaram efeito em nenhuma das características estudadas $(P(F)>0,10)$. As outras características avaliadas neste estudo tinham baixa correlação com a resposta em anticorpos à $E$. coli $\mathrm{e}$ portanto a genotipagem parcial empregada inicialmente foi considerada como sendo feita ao acaso.

Estudos para identificação de QTL em animais de laboratório, onde há disponibilidade de grande número de animais e muitos marcadores disponíveis têm utilizado a genotipagem seletiva como forma de baratear os custos de genotipagem. Kirkpatrick et al. (1998) utilizaram genotipagem seletiva para identificar QTL para prolificidade e crescimento em camundongos de linhagens endogâmicas; de uma população F2 composta por 200 fêmeas distribuídas pelo tamanho médio da ninhada foram genotipadas $25 \%$ das fêmeas, divididas entre as $12,5 \%$ mais e $12,5 \%$ menos prolíficas; freqüências genotípicas no marcador para os grupos de fenótipos superior e inferior foram comparadas pelo teste de qui-quadrado, sob a hipótese nula de igual freqüência genotípica entre os grupos, sendo os marcadores significativos $(P<0,05)$ reexaminados juntos com marcadores flanqueadores para toda a população F2.

Utilizando linhagens endogâmicas de camundongos, Moody et al. (1999) conduziram estudo visando identificar QTL relacionados ao balanço energético desses animais, genotipando seletivamente parte da população em uma primeira fase, utilizando 62 marcadores moleculares distanciados de 20 a $40 \mathrm{cM}$ para genotipar 92 indivíduos divididos entre os de maior e menor perda calórica de uma população experimental de 560 animais. As freqüências genotípicas dos camundongos seletivamente genotipados foram avaliadas utlizando uma análise de qui-quadrado para testar iguais freqüências alélicas entre os grupos de alta e baixa perda calórica, esperada sob a hipótese de ausência de QTL 
ligado; marcadores com valor do qui-quadrado $>2,71$ ( $\mathrm{P}<0,10$; com 1 g.l.) foram avaliados posteriormente em toda a população.

Hain et al. (2000) avaliaram uma população F2 composta por 408 camundongos machos e fêmeas, divergentes quanto ao limiar para ataque convulsivo induzido por cocaína, no intuito de identificar QTL associados a essa característica; a disponibilidade inicial de 1522 marcadores levou à genotipagem seletiva de 72 ratos, divididos entre os de mais alto e mais baixo limiar para convulsão induzida, machos e fêmeas foram equilibrados nesse total, e marcadores com valores de $\mathrm{P}<0,01$ para ligação com $\mathrm{QTL}$, além de um marcador próximo e dois flanqueadores, até uma distância de aproximadamente $10 \mathrm{cM}$, foram genotipados posteriormente para toda a população.

\subsection{Métodos estatísticos para o mapeamento de QTL}

\subsubsection{Métodos de mapeamento}

Mapeamento de QTL engloba os procedimentos de procura, localização e estimativa dos efeitos de um QTL. Os delineamentos usuais utilizados para tal baseiam-se em populações segregantes, onde indivíduos dessas populações (geralmente algumas centenas) são avaliados para os caracteres quantitativos de interesse, e genotipados para vários marcadores moleculares, distribuídos a intervalos regulares ao longo do genoma. Se houver uma diferença na média do fenótipo entre as classes genotípicas do marcador, pode-se inferir que existe um QTL ligado àquele marcador (Coelho \& Silva, 2002).

Segundo Falconer \& Mackay (1996), o número de QTL detectados é sempre subestimado em relação ao número real de locos, devido ao fato de que dois QTL muito próximos podem aparecer como apenas um, se estiverem em associação (ligação entre alelos favoráveis nos dois QTL), ou não serem detectados se estiverem em repulsão (ligação entre um alelo desfavorável e 
outro favorável nos locos). Contudo, de acordo com Coelho \& Silva (2002), ao se usarem técnicas estatísticas para se verificar a ligação entre o marcador e o QTL, também se está sujeito ao erro tipo I, que equivaleria à identificação de um QTL inexistente, chamado QTL "fantasma", fazendo com que a afirmação de Falconer \& Mackay (1996) não seja sempre verdadeira.

Podem ser utilizados umo ou mais marcadores simultaneamente para se avaliar a associação entre marcador e QTL. A análise de marca simples examina a distribuição dos valores do caráter separadamente para cada marcador; assim cada teste é realizado independentemente da informação de outros locos. Lander \& Botstein (1989) relataram que a metodologia tradicional para se detectar um QTL próximo de um único marcador genético, em caso de retrocruzamento, envolve a comparação das médias fenotípicas para duas classes de progênies, com genótipos $A B$ e $B B$, e a diferença entre essas médias daria uma estimativa do efeito fenotípico de se substituir um alelo $B$ por um alelo A para o QTL; nessa situação de marca simples o teste estatístico a ser aplicado sugerido pelos autores poderia ser uma regressão linear.

De acordo com Liu (1998), além de regressão linear simples, teste t, análise de variância ou razão de verossimilhança também podem ser empregados para análise de apenas um marcador; não apresentam aspectos computacionais complicados e não é necessário saber a posição dos marcadores no genoma.

Weller (1986) apresentou o método da máxima verossimilhança como sendo vantajoso para avaliar marcas simples em relação aos outros testes estatísticos, uma vez que esse método consegue estimar a posição do QTL, separando a freqüência de recombinação dos efeitos aditivo e de dominância. O método utiliza o valor fenotípico para determinar os valores de recombinação, as médias estimadas dos genótipos possíveis no QTL e sua variância, sendo as freqüências dos genótipos do QTL condicionadas ao genótipo do marcador ligado. $O$ teste considera na hipótese alternativa $\left(\mathrm{H}_{\mathrm{a}}\right)$ ligação do marcador com o QTL, enquanto a $\mathrm{H}_{0}$ refere-se à ausência de QTL segregando; o logaritmo da 
razão entre $\mathrm{H}_{\mathrm{a}}$ e $\mathrm{H}_{0}$ confere a razão de máxima verossimilhança (log natural), ou pode ser também determinado o LOD "escore" ("log of the odds") utilizando o $\log _{10}$. A identificação da posição do QTL usando o método da máxima verossimilhança é realizada calculando o LOD "escore" para cada possível valor de recombinação. Contudo para marcas simples a localização do QTL pode ser imprecisa.

A análise de marca simples é satisfatória quando o objetivo é simplesmente a detecção de QTL ligados ao marcador, sem se considerar a estimativa de posição e efeitos desse QTL pois, segundo Lander \& Botstein (1989) e Liu (1998), há alguns inconvenientes nessa metodologia: (1) se o QTL não está posicionado no marcador, seu efeito fenotípico pode ser subestimado, pois a variância explicada pelo marcador decresce conforme aumentam as taxas de recombinação, havendo a necessidade de mais progênies genotipadas conforme se distanciam os marcadores; (2) a metodologia não define a posição provável do QTL, se este é um QTL de pequeno efeito e próximo ao marcador ou se é um QTL de grande efeito mas a ligação com o marcador é fraca, pois estão mais distantes e (3) a proporção de falsos positivos considerada, de $\alpha=5$ $\%$, negligencia o fato de que muitos marcadores estejam sendo testados, pois a possibilidade um falso positivo estar ocorrendo em algum lugar no cromossomo ou no genoma é maior do que se estivesse sendo avaliado um único marcador.

Essas desvantagens limitam o uso da análise de marcador simples como passo preliminar para a utilização de técnicas mais complexas, possiblilitando uma varredura de todos os marcores existentes em um segmento ou no genoma como um todo, e eliminação daqueles chamados não informativos (Coelho \& Silva, 2002).

Para solucionar esses problemas pré-descritos, Lander \& Botstein (1989) propuseram a metodologia de mapeamento por intervalo, empregando estimativas de máxima verossimilhança e valores de LOD, indicando o quanto mais provável é que os dados expliquem a presença de QTL do que assumam a sua ausência. No mapeamento por intervalo pode-se estimar o efeito 
fenotípico e o valor de LOD para um QTL putativo em qualquer posição no cromossomo, sendo baseado nas freqüências conjuntas de um par de marcas adjacentes e um QTL pontual, flanqueado por essas duas marcas.

No entanto, conforme afirmaram Haley et al. (1994), a desvantagem dos métodos baseados na máxima verossimilhança para mapeamento de intervalo é sua complexidade computacional, o que torna difícil a extensão do método para permitir a análise simultânea de vários QTL ligados, interações entre QTL, efeitos de QTL não ligados e efeitos fixos, análises simultâneas essas que têm potencial para remover tendências e aumentar o poder do teste.

Haley \& Knott (1992) propuseram o emprego de regressão linear múltipla para mapear QTL flanqueados por dois marcadores em linhagens endogâmicas. Este procedimento fornece estimativas para os efeitos aditivo (a) e de dominância (d) do QTL, bem como define as somas de quadrados e quadrados médios de regressão e desvios, permitindo a realização de testes de hipóteses sobre a e $d$; a posição do QTL entre as marcas que gerar o melhor ajuste do modelo (menor soma de quadrados de resíduos) fornece a posição mais provável do QTL e as melhores estimativas de seus efeitos. Contudo, conforme afirmaram Haley et al. (1994), em cruzamentos entre linhagens endogâmicas os marcadores selecionados para o mapeamento têm heterozigozidade igual a um, o que significa dizer que não há perda de informação entre dois marcadores flanqueando um QTL.

Entretanto, em muitos casos, como ocorre freqüentemente com animais, o mapeamento de QTL utiliza indivíduos provenientes de cruzamentos entre linhagens que são geneticamente divergentes, mas são não endogâmicas. Segundo Beckmann \& Soller (1988) e Mackay (2001), um problema potencial na análise de populações não endogâmicas é que os marcadores não são completamente informativos e variam em sua heterozigozidade nos indivíduos F1; eles recomendam uma varredura inicial nesses indivíduos para descartar marcadores que não sejam informativos. No entanto, determinados marcadores podem estar segregando dentro de famílias e serem informativos em animais 
F2 pertencentes apenas a elas, variando o conteúdo da informação dependendo do marcador.

Haley et al. (1994), discorrendo sobre populações originadas de linhagens não endogâmicas, afirmaram que o uso de apenas dois marcadores flanqueando um possível QTL pode levar a uma situação de variabilidade de informação, e conseqüentemente de poder de teste, de intervalo a intervalo, dependendo dos marcadores que os flanqueiam. Os autores desenvolveram um método que permite a aplicação de quadrados mínimos ao mapeamento de QTL em cruzamentos de linhagens não endogâmicas, utilizando dados de todos os marcadores em um grupo de ligação simultaneamente; esse método tornaria o uso dos marcadores mais eficiente, maximizando o poder do teste $\mathrm{e}$ minimizando o risco de estimativas tendenciosas.

O modelo proposto por Haley et al. (1994) permite utilizar informação de marcadores flanqueadores para determinar a fase de ligação dos alelos nos parentais e inferir a origem dos alelos de marcadores não-informativos; a metodologia considera a priori que um possível QTL tenha seus alelos fixados nas linhagens fundadoras da população, com alelos $Q$ e q para o QTL, independentemente dos alelos para os marcadores não estarem fixados. Então, pode-se determinar qual a probabilidade de ocorrência dos genótipos QQ, Qq, qQ e qq em cada posição investigada, para cada indivíduo .

Entre as vantagens do método de mapeamento por intervalo estão: (1) o mapa provável de QTL representa claramente a evidência para QTL em vários pontos em todo o segmento analisado, (2) o mapeamento por intervalo requer uma progênie menor do que a necessária no método tradicional e (3) permite que sejam utilizados marcadores que não sejam totalmente informativos em mapeamento de QTL em populações F2 originadas de cruzamentos não endogâmicas.

Conforme relacionou Liu (1998), os principais problemas com mapeamento por intervalo são: (1) o número de QTL não pode ser definido, (2) a localização dos QTL algumas vezes não é bem definida, sem conhecimento 
exato de sua posição e (3) o poder estatístico ainda é relativamente baixo; as causas possíveis desses problemas são a presença de QTL ligados, interações entre eles e informações limitadas no modelo empregado. Uma das conseqüências dos problemas citados é o surgimento de picos "fantasmas" indicativos de QTL, devidos à presença de "background" genético, advindo de outros QTL ligados.

Zeng (1993) teorizou o emprego de regressão linear múltipla combinada ao mapeamento de intervalo proposto por Lander \& Botstein (1989) como um teste estatístico que permitiria mapear QTL em cada intervalo (CIM "Composite Interval Mapping"), independentemente dos efeitos de outros possíveis QTL nas demais regiões do cromossomo. Embora Zeng (1993) tenha proposto em seu trabalho o emprego da razão de máxima verossimilhança preconizada no método de Lander \& Botstein (1989), o enfoque de Haley \& Knott (1992) de quadrados mínimos também pode ser empregado em associação com a regressão linear múltipla, o que poderia representar mais simplicidade nas análises computacionais.

As vantagens do método proposto por Zeng (1993), são, segundo Liu (1998): (1) executa-se uma busca unidimensional, concentrada em apenas uma região do genoma, propiciando que a estimativa de localização e efeito dos QTL seja assintoticamente não tendenciosa; (2) a resolução de localidade dos QTL pode ser muito maior do que por análises de marcas simples ou mapeamento de intervalo e (3) há mais variáveis no modelo do que nas outras análises, portanto o CIM seria mais informativo e eficiente.

Trabalhando com cruzamento de linhagens não endogâmicas de suínos distintas fenotipicamente, Andersson et al. (1994) publicaram dados preliminares utilizando o enfoque de Haley et al. (1994) para mapear QTL em indivíduos F2 fazendo uso de múltiplos marcadores no mesmo cromossomo. Posteriormente Knott et al. (1998) fizeram uma série de análises nessa mesma população empregando uma estrutura de quadrados mínimos, e utilizando modelos com efeitos fixos de sexo e parição e considerando efeito aleatório de 
famílias, além de adicionar cofatores ao modelo (localização dos marcadores) para isolar efeitos de QTL em outros cromossomos, seguindo o principio proposto por Zeng (1993). A omissão dos cofatores de maneira geral causou decréscimo no número de localizações sugestivas de QTL. Os autores concluíram que a adição de cofatores no modelo para o cromossomo que está sendo mapeado possibilitou mais precisão na localização de QTL e maior poder de teste, quando houve suposição de QTL adicionais ligados.

Knott et al. (1998) também apresentaram uma extensão do modelo para que fosse testado efeito de imprinting gamético, quando um QTL fosse identificado. O modelo considerando o imprinting poderia explicar melhor o QTL do que o modelo mendeliano. O fenômeno de imprinting ocorre quando os genomas parentais sofrem modificações durante a gametogênese, resultando na expressão incompleta ou ausência de expressão de alguns genes herdados de um dos parentais (de Koning et al., 2002).

O uso de pacotes estatísticos desenvolvidos para mapear QTL facilita o mapeamento de QTL para características múltiplas. Seaton et al. (2001) desenvolveram programa para mapeamento de QTL, o QTL Express, com interface para o usuário na web (http://qtl.cap.ed.ac.uk). O programa utiliza análise de regressão e é adequado para populações não endogâmicas; permite o mapeamento de QTL simples ou múltiplos, a adição de efeitos fixos adicionais e covariáveis no modelo, além do uso de QTL adicionais como cofatores. $\mathrm{Na}$ análise de cruzamentos de linhagens não endogâmicas o modelo para o QTL pode incluir o efeito da origem parental do alelo. No QTL Express também podem ser implementados testes de permutação para se obter os níveis de significância (Churchill \& Doerge, 1994) e procedimento de bootstrap para estimar o intervalo de confiança da localização de um QTL (Visscher et al. 1996). 


\subsubsection{Níveis de significância e intervalo de confiança}

Lynch \& Walsh (1998) afirmaram que uma consideração importante a ser feita em relação à estatística de mapeamento de QTL é o nível apropriado de significância a ser considerado em um experimento completo de mapeamento, pois em cada experimento um número elevado de testes associando marcadores à característica é normalmente processado. Mesmo que o nível de significância $\alpha$ encontrado em cada teste seja muito pequeno, ainda há uma alta probabilidade de que haja um falso positivo no total de testes executados.

Se testes independentes de associação são conduzidos, ou seja, se os marcadores estão posicionados em diferentes cromossomos e portanto não estão ligados, então pode ser empregada a correção de Bonferroni para múltiplas comparações (Lynch \& Walsh, 1998).

Lander \& Kruglyak (1995) fizeram considerações sobre os níveis de significância, afirmando que um nível de significância pontual deveria ser considerado apenas como sugestivo, e que os níveis genômicos de 5 e 1\% deveriam ser obtidos empregando-se a correção de Bonferroni. Esses autores recomendam que três níveis de significância deveriam ser considerados, o primeiro deles a significância para considerar a ligação sugestiva, correspondendo a um falso positivo apenas ocorrendo em todo o genoma, o segundo a significância a 5\% no genoma, correspondendo à ligação significativa, e o terceiro a significância a 1\% no genoma, caracterizando uma ligação altamente significativa.

Se os autores de trabalhos de mapeamento desconsideram o fato de que alguns testes podem não ser independentes, então o principio da correção pode estar sendo violado e os valores de significância genômicos podem estar aquém dos valores desejados. Quando os testes não são independentes, envolvendo marcadores ligados, uma solução é utilizar procedimentos de reamostragem. Churchill \& Doerge (1994) propuseram testes de permutação, nos quais as análises são refeitas após embaralhamento dos valores 
fenotípicos enquanto são preservados os genótipos para cada indivíduo. O teste estatístico é computado para cada reamostragem gerando uma distribuição empírica do teste sob a hipótese de não associação do marcador à característica. Esses mesmos autores sugerem que 1000 reamostragens são suficientes para um nível de significância de 5\% no genoma, e que 10000 ou mais são requeridas para gerar um valor critico estável para o nível de $1 \%$ no genoma.

Trabalhos de mapeamento de QTL em aves publicados nos últimos anos têm empregado os níveis de significãncia propostos por Lander \& Kruglyak (1995).

O intervalo de confiança de $95 \%$ para a posição de QTL encontrados em um experimento pode ser calculado satisfatoriamente pelo método de reamostragem "bootstrap" proposto por Visscher et al. (1996), no qual subamostras são retiradas do total das observações, gerando uma nova população que será submetida a analise estatística para identificação de QTL. As amostragens são feitas com reposição, permitindo que alguns valores nunca apareçam e outros sejam considerados mais de uma vez. Todas as estimativas obtidas devem ser ordenadas e 2,5\% valores de cada extremo devem ser desconsiderados, resultando no intervalo de valores - ou intervalo de confiança - de 95\% para a provável posição do QTL.

\subsection{Populações-referência e o mapa consenso}

O número razoável de marcadores já existentes permitiu a publicação do mapa de ligação consenso para três populações-referência, obtido pela intersecção dos marcadores posicionados nos mapas de ligação pré-existentes de cada uma delas (Groenen et al., 2000).

A primeira população experimental de frangos a ter um mapa de ligação publicado baseado totalmente em marcadores do DNA foi a família-referência Compton, gerada no Institute for Animal Health, em Compton, no Reino Unido 
(Bumstead \& Palyga, 1992). As linhagens parentais foram selecionadas pela sua diferente susceptibilidade a doenças, especialmente salmonelose e doença de Marek, e foram empregadas em ensaios de desafio sanitário. Foram acasalados inicialmente um macho da linhagem 151 com uma fêmea da linhagem N; uma fêmea F1 foi retrocruzada com um macho da linhagem 151, formando a população-referência $C$, a qual gerou o mapa de ligação $C$ a partir do DNA de 56 indivíduos. Cheng (1997) observou que, como conseqüência de se empregar uma fêmea F1 heterogamética no retrocruzamento, o cromossomo $Z$ não pode ser mapeado na família-referência $C$, mas é possível mapear a região pseudoautossomal do cromossomo $\mathrm{W}$.

O segundo mapa genético publicado para Gallus sp. foi baseado na família-referência East Lansing (EL), da Michigan State University, em conjunto com o Agricultural Research Service Avian Disease and Oncology Laboratory (Cheng, 1997; Levin et al., 1993 e 1994). As duas linhagens formadoras, a parcialmente endogâmica UCD-001, derivada da "Red Jungle Fowl" (JF), e a endogâmica UCD-003, derivada da "White Leghorn" (WL), foram selecionadas por apresentarem distância genética suficiente para permitir identificação de polimorfismos (Crittenden et al., 1993)

Na formação da população, um macho UCD-001 foi acasalado com uma fêmea UCD-003 para produzir a geração F1; dois machos F1 foram individualmente acasalados com dois grupos, de oito e 10 fêmeas UCD-003, produzindo por retrocruzamento progênies com 192 e 208 aves, respectivamente para cada grupo, das quais 52 formaram a base da populaçãoreferência EL. O DNA dessa população foi distribuído para vários laboratórios em todo o mundo para identificação de marcadores e criação do mapa de ligação EL (Cheng, 1997).

Ao considerar-se essas duas populações referência, deve ser lembrado que para se obter frações de recombinação suficientes que permitam a construção de um mapa genético confiável é preciso um número elevado de meioses informativas, evitando-se assim tendenciosidade, e espaçamento ideal 
entre marcadores, que permita determinar a ligação entre dois ou vários marcadores ligados no mesmo grupo de ligação. Distâncias muito pequenas dificultam o seu ordenamento correto, pela dificuldade de se obter recombinação (Groenen et al., 1998).

O ordenamento dos marcadores posicionados nessas duas populaçõesreferência pode não estar correto, uma vez que a ordem e as distâncias estão relacionadas com o número de eventos meióticos, e eles são pouco mais de 50 em cada uma das populações. Esse número de meioses é suficiente para detectar ligação a distâncias de até $30 \mathrm{cM}$, mas não é totalmente confiável para distâncias menores onde apenas um ou alguns poucos recombinantes bem como erros na tipificação podem alterar bastante o posicionamento do marcador (Cheng, 1997 e Groenen et al., 1998).

A terceira população experimental de frangos foi criada a partir de um modelo de delineamento populacional de três gerações sugerido por Van der Beek et al. (1995) apropriado para a detecção de QTL, na qual a genotipagem é feita nas duas primeiras gerações e o fenótipo é obtido na terceira geração. A população-referência WAU foi desenvolvida pelo Animal Breeding and Genetics Group da Wageningen University, em Wageningen, Holanda, em colaboração com a Euribrid B.V., utilizando na sua formação duas linhagens extremas de frango de corte derivadas da "White Plymouth Rock", sendo a linhagem materna de relativamente alto desempenho reprodutivo e a paterna de relativamente alto desempenho em crescimento.

A população se iniciou com 14 machos e 14 fêmeas, e 10 animais de cada sexo obtidos desse cruzamento foram acasalados, produzindo famílias de irmãos completos nessa segunda geração; 476 animais foram genotipados no total (Groenen et al., 1998). Nessa população experimental foram mapeados primariamente marcadores microssatélites, gerando o mapa de ligação WAU, com o intuito de se localizar QTL; posteriomente foram mapeados AFLPs e mais marcadores microssatélites. 
Os dados de genotipagem derivados dessas três populações-referência (C, EL e WAU) foram combinados e analisados simultaneamente. O posicionamento de cada um dos marcadores em mais de um mapa de ligação possibilitou a Groenen et al. (2000) desenharem um mapa único, inserindo ordenadamente 480 locos em 50 grupos de ligação comuns, e 1409 locos não consenso foram posicionados em relação a esses 50 grupos de ligação, totalizando 1889 locos no mapa consenso do genoma da galinha; o número de locos diferentes em ao menos uma das três populações chegou a 2019 marcadores, porém 95 deles não estavam ligados e 35 não puderam ser posicionados com clareza em seus mapas de ligação, sendo omitidos do mapa final.

Schmid et al. (2000) publicaram pouco tempo depois uma atualização desse mapa. Atualmente há cerca de 2519 locos posicionados no genoma da galinha, dos quais 754 são designados como genes (http://www.thearkdb.org).

O comprimento mínimo estimado para o mapa consenso da galinha é de 3800 cM; se os 480 marcadores posicionados fossem igualmente distribuídos o intervalo entre eles seria de cerca de $8 \mathrm{cM}$, mas há intervalos grandes 0 suficiente em alguns pontos para inviabilizar a busca de QTL nessas regiões.

A proporção de marcadores de alto polimorfismo bem como o número de meioses informativas empregadas sugere confiabilidade no ordenamento e intervalos entre os marcadores tipo I e II no mapa consenso, habilitando-o como instrumento na escolha de marcadores e na comparação de ordenamento destes em outras populações estudadas, a partir da sua publicação. Outras populações experimentais foram desenvolvidas com o intuito de se localizarem QTL, tendo parentais de linhagens divergentes para características específicas como base de formação, mas empregando os marcadores mapeados nessas populações-referência precursoras. Grande parte dos marcadores de DNA mapeados tem "primers" disponibilizados pelo Chicken Genome Project, viabilizando estudos de QTL em aves por diferentes grupos de pesquisa (http://www.poultry.mph.msu.edu) . 


\subsection{QTL identificados em galinhas}

Desde a incorporação de grande número de marcadores moleculares aos mapas de ligação do genoma a galinha, muitos QTL associados a características diversas já foram mapeados. Os primeiros trabalhos publicados em sua maioria estavam relacionados com resistência a doenças; posteriormente o enfoque também passou a ser a avaliação de parâmetros de desempenho e qualidade de carcaça. Nos últimos anos outras características de interesse econômico têm sido estudadas, um exemplo é o comportamento de bicar a plumagem de outras aves, geralmente em resposta ao estresse (Buitenhuis et al., 2003).

Yonash et al. (2001) afirmaram que a resposta imunológica em frangos é uma característica quantitativa típica, de baixa a média herdabilidade, sendo desejável a utilização da MAS para essa característica. O mesmo objetivo tem justificado os trabalhos de mapeamento de QTL associados a desempenho e carcaça em aves (Van Kaam et al., 1999a), a exemplo do que já ocorre com suínos.

Vallejo et al. (1998) genotiparam 77 microssatélites distribuídos ao longo do genoma em uma população F2 originada do cruzamento entre linhagens endogâmicas, uma delas resistente ao vírus causador da doença de Marek (DM), para mapear QTL afetando a susceptibilidade ao vírus. Dois QTL significativos e dois sugestivos, nos cromossomos 2, 8, 4 e 7 respectivamente, afetando vários componentes da DM foram localizados.

A publicação de Vallejo et al. (1998), segundo os autores, foi a primeira a mapear QTL para resposta imune em frangos domésticos, não relacionados ao complexo principal de histocompatibilidade, utilizando ferramentas de genética molecular. O sucesso na localização de QTL nessa pesquisa possivelmente também se relacionou com o perfil da característica avaliada pois, do número total de genes envolvidos em herança poligênica para resistência a doenças, 
somente uns poucos genes parecem ser responsáveis por 60-70\% da variação genética (Vallejo et al., 1998).

Yonash et al. (2001) posteriormente avaliaram resposta imune em frangos, porém utilizando população originada do cruzamento de linhagens não endogâmicas de frangos de corte, com baixa e alta respostas em anticorpos à Escherichia coli. Foram uitlizados 25 marcadores microssatélites distanciados entre si menos de $40 \mathrm{cM}$, cobrindo cerca de 25\% do genoma. As aves F2 foram avaliadas quanto a suas respostas imunológicas a vacina do vírus atenuado de Newcastle, e injeções contendo E. coli e hemácias de carneiro. Foram encontrados três marcadores associados significativamente com QTL, nos cromossomos 2, 5 e no grupo de ligação 31.

Possivelmente a primeira publicação sobre QTL associados a desempenho em frangos foi o trabalho de tese de Khatib (1994), citado por Van Kaam et al. (1999a), no qual o autor estudou taxas de crescimento juvenil. Posteriormente, Van Kaam et al. (1999a) fizeram varredura de 27 grupos de ligação utilizando 420 marcadores informativos à procura de QTL para crescimento e eficiência alimentar. Em seu experimento Van Kaam et al. (1999a) genotiparam um total de 471 aves das gerações 1 e 2 e avaliaram até 2146 fenótipos na geração 3 para as características peso corporal aos 23 dias, peso corporal aos 48 dias (P48), ingestão alimentar em intervalo fixo de idade (IAIA), ingestão alimentar em intervalo fixo de peso (IAIP), crescimento (C) e eficiência alimentar entre 23 e 48 dias. Foram encontrados quatro QTL: no cromossomo 1, significativo para IAIA e sugestivo para P48 e C; no cromossomo 2, sugestivo para IAIP; no cromossomo 4 sugestivo para IAIA e no grupo de ligação WAU26, sugestivo para IAIA. A coincidência na posição de QTL para diferentes características em um mesmo cromossomo era esperada, pela correlação existente entre as características.

Van Kaam et al. (1999b) utilizaram os mesmos marcadores que no trabalho acima citado para mapear QTL para características de carcaça. Os autores utilizaram dados fenotípicos de aproximadamente 1953 aves da 
geração 3 e genótipos de 469 indivíduos das gerações 1 e 2. As características avaliadas foram peso vivo aos 48 dias (P48), peso de carcaça (PC), percentagem de carcaça, coloração da carne (CC) e pontuação para pernas. Foram encontrados dois QTL sugestivos, um no cromossomo 1 para PC e outro no cromossomo 2, para CC e CC ajustada para P48, sendo possível a existência de mais de um QTL no cromossomo 2, já que ocorreram picos em posições próximas, mas distintas. Apesar de não terem apresentado ligação sugestiva, os autores apontam a região flanqueada pelos marcadores LEI 166MCW116 no cromossomo 3 como potencialmente interessante.

Marcadores ligados a QTL afetando peso corporal a 13 e 16 semanas de idade em frangos também foram identificados por Tatsuda \& Fujinaka (2001), em uma população $F 2$ originada do cruzamento de uma raça nativa de crescimento lento com outra de crescimento rápido. Os QTL mapeados estavam posicionados no cromossomo 1 a $220 \mathrm{cM}$, e no cromossomo 2 a 60 cM.

O posicionamento do QTL no cromossomo 1 identificado por Tatsuda \& Fujinaka (2001) confirma o posicionamento obtido previamente no mesmo cromossomo entre 220 e 240 cM para P48 (Groenen et al., 1997; Van Kaam et al., 1998 e 1999a) e IAIA (Van Kaam et al., 1999a); A ausência de marcadores posicionados a 40 cM não permitiu que Tatsuda \& Fujinaka (2001) afirmassem com certeza que o QTL localizado no cromossomo 2 fosse o mesmo localizado nesta posição por Van Kaam et al. (1999a).

Dados preliminares de pesquisa relacionando marcadores moleculares e QTL para crescimento e características da carcaça foram publicados por McElroy et al. (2002), baseados em uma população experimental obtida de linhagens divergentes de frangos de corte. Foram genotipados 50 marcadores microssatélites em 19 cromossomos. As características mensuradas foram peso anterior ao transporte para abate (6 semanas), peso pós-transporte e sete características da carcaça. Foram localizadas nove posições significantes para QTL, três no cromossomo 2, três no cromossomo 3, uma no cromossomo 7, 
uma no cromossomo 13 e uma no cromossomo Z; também foram observadas ligações sugestivas em uma posição no cromossomo 5 , e outras nos cromossomos 23, 26 e 27 (uma em cada).

A despeito da falta de significância obtida para QTL no cromomossomo 5 na pesquisa de McElroy et al. (2002), nove diferentes características tiveram relação sugestiva com o único marcador posicionado nesse cromossomo. Anteriormente o único QTL mapeado no cromossomo 5 foi relacionado à resposta imune (Yonash et al., 2001)

Tuiskula-Haavisto et al. (2002) mapearam QTL afetando características produtivas e de qualidade do ovo em cruzamento de linhagens de poedeiras. Ao todo 99 marcadores microssatélites com espaçamento médio de $23 \mathrm{cM}$ estavam distribuídos em nove macrocromossomos e cinco grupos de ligação, permitindo mapear quatorze QTL significativos e seis sugestivos, nos cromossomos 2, 3, 4, 5 , 8 e Z.

Sewalem et al. (2002) genotiparam 466 aves distribuídas em 30 famílias F2 de uma população desenvolvida a partir de linhagem de corte comercial e linhagem de postura, utilizando 101 marcadores posicionados em 27 grupos de ligação e espaçamento médio de $40 \mathrm{cM}$; mapearam QTL significativos para peso corporal a três e seis semanas de idade nos cromossomos 1, 2, 4, 7 e 8 e a três, seis e nove semanas no cromossomo 13.

Ikeobi et al. (2002) utilizaram a mesma população empregada por Sewalem et al. (2002); 442 indivíduos de 30 famílias foram analisados para características associadas à gordura na carcaça e genotipados, sendo mapeados QTL significativos para essas características nos cromossomos 1, 3, 5, 7, 1315 e 28, e QTL sugestivos nos cromossomos 2, 4 6, 9 e Z.

Recentemente, Buitenhuis et al. (2003a) avaliaram o comportamento de bicar a plumagem de outras aves em resposta ao estresse. Esses autores trabalharam com uma população $\mathrm{F} 2$ de 630 galinhas poedeiras da fase jovem à adulta, observando diferentes graus de severidade no bicar e resposta em nivel de corticosterona após manuseio e mapearam dois QTL significativos e treze 
sugestivos para as características avaliadas. Os autores relataram a detecção um QTL no cromossomo 5 relacionado ao nível de corticosterona produzida, com possível efeito da origem parental do alelo, fenômeno conhecido como imprinting genético.

Siwek et al. (2003) avaliaram resposta imune de galinhas poedeiras à injeção de hemácias de carneiros; mapearam um QTL significativo e seis sugestivos para resposta imune à hemácias de carneiros e observaram efeito da origem parental do alelo em dois dos QTL sugestivos.

Embora não se trate do foco deste estudo, os resultados obtidos por Buitenhuis et al. (2003a) e Siwek et al. (2003) contradizem a teoria do imprinting formulada por Moore \& Haig (1991), pela qual o fenômeno não ocorreria necessariamente em aves. Esses resultados encontrados, conflitantes com essa teoria, abrem um campo de interesse para estudo dos efeitos da origem parental dos alelos sobre QTL influenciando as mais variadas características.

O poder de detecção de QTL está relacionado com a divergência existente nas linhagens parentais para a característica de interesse e no número e informatividade de marcadores empregados. Essas diferenças estão presentes nos trabalhos mencionados.

O posicionamento de um mesmo QTL também pode variar ou mesmo não ser detectado dependendo do mapa de ligação empregado. Enquanto muitos autores utilizaram o mapa consenso, outros preferiram desenvolver mapa próprio. O mapa de ligação desenvolvido na população WAU foi empregado posteriormente nos experimentos conduzidos por seus autores (Groenen et al., 1997, Van Kaam et al., 1998, Van Kaam et al., 1999a e1999b).

Tatsuda \& Fujinaka (2001) também utilizaram as distâncias do mapa de ligação WAU para posicionar seus marcadores, justificando seu emprego pelo fato de que uma das linhagens utilizada na sua população foi empregada no desenvolvimento da população WAU.

Vallejo et al. (1998) desenvolveram mapa genético para sua população utilizando programa apropriado para linhagens endogâmicas (MAPMAKER I 
EXP, Lander et al., 1987). Tuiskula-Haavisto et al. (2002) também optaram por desenvolver e utilizar mapa de ligação próprio, usando recursos do programa CRI-MAP (Green et al., 1990).

Ikeobi et al. (2002) e McElroy et al. (2002) consideraram as posições para os marcadores empregados em seus estudos como sendo as mesmas dadas no mapa consenso 2000. Sewalem et al. (2002) construíram mapa de ligação para a população, mas devido à similaridade com o mapa consenso, este foi utilizado em suas análises de mapeamento.

Os resultados obtidos em trabalhos de mapeamento indicam que diferentes populações experimentais têm possibilitado encontrar QTL para diferentes características. Alguns QTL contudo foram detectados apenas uma vez, sendo desejável seu mapeamento em outras populações experimentais.

Além disso, se os maiores cromossomos já possuem número suficiente de locos mapeados para permitir uma busca adequada por QTL, os resultados obtidos sugerem que a procura por QTL ligados a caracteríticas de grande interesse comercial, tais como gordura e porcentagem de partes nobres carcaça devem ser intensificados. Em especial nos cromossomos 3 e 5 os QTL mapeados são poucos e suas posições necessitam ser confirmadas.

Os objetivos deste trabalho, a partir de uma população-referência desenvolvida pela EMBRAPA - Suínos e Aves, obtida do cruzamento de uma linha paterna de aves para corte com outra de postura em delineamento de três gerações, são: (1) desenhar mapas de ligação específicos para os cromossomos 3 e 5 empregando marcadores microssatélites informativos, a partir do DNA de no mínimo 400 aves F2 pertencentes à população-referência desenvolvida pela EMBRAPA - Suínos e Aves; (2) mapear QTL associados a características de desempenho e de carcaça nos cromossomos 3 e 5 , empregando marcadores com distâncias de aproximadamente $20 \mathrm{cM}$ entre eles. 


\section{MATERIAL E MÉTODOS}

\subsection{População experimental}

A população referência utilizada foi desenvolvida pela Empresa Brasileira de Pesquisa Agropecuária - Suínos e Aves (EMBRAPA-CNPSA), em Concórdia, SC. Foram escolhidas duas linhagens fundadoras, uma de corte (TT) e outra de postura (CC). A linhagem TT é uma linha de macho, cuja seleção é efetuada dentro de linha, tendo como objetivo melhorar geneticamente o potencial para peso corporal, conversão alimentar, consumo de ração, redimento de carcaça e partes, viabilidade, fertilidade e eclodibilidade; redução da gordura abdominal e das doenças metabólicas. Essa linhagem vem sendo selecionada por seis gerações. A linhagem CC vem sendo selecionada por oito gerações para as características de produção de ovos, peso do ovo, redução do peso corporal, conversão alimentar, viabilidade, maturidade sexual, fertilidade, eclodibilidade e qualidade do ovo.

Essas linhagens foram submetidas previamente a ensaio de desempenho comparativo (Ledur et al., 2000). A linhagem de corte TT apresentou peso vivo médio aos 41 dias de idade de 2395,4 g, rendimento de carcaça de $74,6 \%$, e 20,4 e 2,41 g de rendimento de peito e de porcentagem de gordura na carcaça, respectivamente. A linhagem de postura CC pesou quase 5 vezes menos, apresentando peso vivo aos 41 dias de $513,7 \mathrm{~g}, 64,2 \%$ de rendimento de carcaça, e 14,2 e 0,16 g de rendimento de peito e porcentagem de gordura, respectivamente, indicando que as linhagens são bastante divergentes relativas a desempenho e características de carcaça. 
As duas linhagens foram empregadas em cruzamentos recíprocos, na proporção de um macho para cada fêmea, empregando-se sete machos e sete fêmeas de cada linhagem para formação de cada cruzamento recíproco. As aves tiveram seus pedigrees controlados e foram mantidas em gaiolas individuais; os ovos gerados foram identificados para permitir o anilhamento dos pintos ao nascer.

A primeira geração obtida desses cruzamentos foi chamada F1; essa geração foi formada por sete famílias obtidas do cruzamento de macho de corte com fêmea de postura (TC) e sete famílias obtidas do cruzamento de macho de postura com fêmea de corte (CT), todas de irmãos completos, cada uma representada por três machos e seis fêmeas escolhidas ao acaso. As aves da geração F1 foram alojadas em gaiolas individuais e criadas como matrizes de corte. Dentro de cada uma das famílias F1 foram selecionados um macho e três fêmeas; cada macho gerou progênies com três fêmeas de outras famílias, através de inseminação artificial, evitando-se o acasalamento de parentes próximos. A geração obtida desses cruzamentos foi chamada F2; com cerca de 100 pintos por casal F1, produzidos em 17 incubações, com 3823 aves, sendo 2063 descendentes do cruzamento TC e 1760 do cruzamento CT, com equilíbrio númerico entre machos e fêmeas.

Os cruzamentos obtidos na geração F1 tiveram seu desempenho avaliado por Ledur et al. (2000), e apresentaram valores para características de desempenho e qualidade de carcaça intermediários aos apresentados pelas linhagens fundadoras. O presente trabalho foi conduzido avaliando apenas os indivíduos do cruzamento TC (Tabela 1).

A estrutura populacional delineada para os cruzamentos permitiu que grande parte dos animais da geração F2 sejam aparentados, possibilitando análises entre irmãos completos e entre meio-irmãos (Tabela 2).

As aves da geração $\mathrm{F} 2$ foram identificadas com anilhas o que permitiu o controle individual de seus pedigrees, sendo criadas como frangos de corte. Essas aves tiveram seu desempenho avaliado por todo o período criatório até o 
abate aos 42 dias de idade, quando foram obtidas medidas referentes às carcaças (encontram-se no banco de dados do Setor de Melhoramento de Aves da EMBRAPA - Suínos e Aves).

Tabela 1. Estrutura populacional do cruzamento TC, número de aves empregadas nas análises e o tipo de dados coletados

\begin{tabular}{ccccc}
\hline Geração & Machos & Fêmeas & Total & Dados coletados \\
\hline Parental & 7 & 7 & 14 & genótipos \\
F1 & 7 & 20 & 27 & genótipos \\
& & & & fenótipos \\
F2 & 1039 & 1024 & 2063 & genotipagem seletiva \\
& $(84)$ & $(86)$ & $(170)$ & genótipos ${ }^{1}$ \\
& 275 & 275 & 550 &
\end{tabular}

Tabela 2. Relações de parentesco nas famílias originadas do cruzamento TC ${ }^{1}$

\begin{tabular}{|c|c|c|c|c|c|c|c|}
\hline \multicolumn{8}{|l|}{$\begin{array}{c}\text { Casal } \\
\text { Parental: }\end{array}$} \\
\hline & $\underline{5649}$ & 5661 & 5561 & 6232 & 5921 & 6037 & $\underline{5596}$ \\
\hline macho TT & 886 & 88 & 570 & 332 & 37 & $\overline{241}$ & 05 \\
\hline fêmea CC & (1) & (2) & (3) & (4) & (5) & (6) & (7) \\
\hline \multicolumn{8}{|l|}{ Casal F1: } \\
\hline machoTC & 7716 (1) & 7769 (2) & $\underline{7797(3)}$ & $7822(4)$ & $7975(5)$ & $7977(6)$ & 7985 (7) \\
\hline \multirow{3}{*}{$\begin{array}{c}\text { fêmeasTC } \\
\text { (no casal } \\
\text { parental) }\end{array}$} & $7761(7)$ & $7749(6)$ & $\overline{7972(5)}$ & $7765(2)$ & $7713(3)$ & $7722(1)$ & $7805(1)$ \\
\hline & 7810 (4) & 7816 (4) & 7812 (4) & 7971 (5) & $7980(7)$ & 7771 (2) & 7736 (4) \\
\hline & $7978(6)$ & 7709 (3) & 7992 (2) & 7798 (3) & 7755 (6) & 7987 (7) & 7743 (5) \\
\hline \multirow{3}{*}{$\begin{array}{l}\text { F2 gerados } \\
\text { (№ mãe F1) }\end{array}$} & $100(7761)$ & 96 (7749) & 99 (7972) & 73 (7765) & 95 (7713) & 102 (7722) & $88(7805)$ \\
\hline & 77 (7810) & 97 (7816) & 100 (7812) & $100(7971)$ & $104(7980)$ & 100 (7771) & 103 (7736) \\
\hline & $100(7978)$ & 100 (7709) & 108 (7992) & $97(7798)$ & 101 (7755) & $80(7987)$ & 102 (7743) \\
\hline
\end{tabular}

\footnotetext{
${ }^{1}$ Os números apresentados são aqueles equivalentes aos das anilhas nas aves.
} 


\subsection{Coleta dos dados fenotípicos e de sangue das aves}

Os dados de desempenho e características da carcaça avaliados no trabalho foram obtidos durante a criação das aves e na fase pré e pós-abate (Tabela 3). O peso da carcaça e das partes e o sangue para leitura do hematócrito foram colhidos no momento do abate das aves.

As medidas de ganho de peso foram obtidas subtraindo-se do peso medido o peso da ave no início de cada período considerado, a ração fornecida e as sobras foram medidas no período compreendido entre o $35^{\circ}$ e o $41^{\circ}$ dias, permitindo que fossem calculados o consumo no período, a conversão e a eficiência alimentar. As partes denominadas coxas são referentes as coxas e sobrecoxas em conjunto e o peso obtido se refere ao par, o mesmo ocorrendo para as asas, pés e pulmões. Por peso de carcaça entende-se a soma do peito, costas, coxas e asas. As medidas dadas em porcentagem foram obtidas multiplicando-se o peso da característica po 100 e dividindo pelo peso vivo aos 42 dias (peso em jejum, pré-abate).

Depois de pesadas, as carcaças foram estocadas para posterior análise bromatológica a ser efetuadada EMBRAPA - Suínos e Aves. O sangue de todas as aves foi coletado em tubo contendo EDTA 10\% para evitar coagulação e estes foram armazenados a $-70^{\circ} \mathrm{C}$ para posterior extração do DNA. Os parentais tiveram sangue extraído da veia braquial em três tomadas de 1,6 mL /semana, totalizando $5 \mathrm{~mL}$. As aves das gerações F1 e F2 puderam ter uma quantidade maior de sangue extraída, pois este foi coletado durante o abate, no processo de sangria dos animais.

A conclusão dos abates ocorreu em agosto de 2000; em janeiro de 2001 todo o sangue coletado foi separado em alíquotas, organizadas segundo a família a que pertenciam as aves. Parte desse sangue aliquotado está armazenado no Laboratório de Biotecnologia Animal da ESALQ-USP em Piracicaba, SP; o restante permanece em um banco de sangue na EMBRAPA Suínos e Aves, para estudos posteriores. 
Tabela 3. Lista das características de desempenho e carcaça avaliadas

\begin{tabular}{|c|c|}
\hline Característica & Símbolo \\
\hline Peso ao nascer (g) & $\mathrm{PN}$ \\
\hline Peso aos 35 dias de idade (g) & PV35 \\
\hline Peso aos 41 dias de idade (g) & PV41 \\
\hline Peso aos 42 dias de idade (pré-abate) (g) & PV42 \\
\hline Ganho de peso do nascimento aos 35 dias (g) & GPN35 \\
\hline Ganho de peso do nascimento aos 41 dias (g) & GPN41 \\
\hline Ganho de peso do nascimento aos 42 dias (g) & GPN42 \\
\hline Ganho de peso dos 35 aos 41 dias (g) & GP35-41 \\
\hline Conversão alimentar dos 35 aos 41 dias & $\mathrm{CA}$ \\
\hline Eficiência alimentar dos 35 aos 41 dias & EF \\
\hline Consumo de ração dos 35 aos 41 dias (g) & $\mathrm{CR}$ \\
\hline Peso da carcaça (g) & CARC \\
\hline Peso do peito $(\mathrm{g})$ & PEIT \\
\hline Peso das costas $(\mathrm{g})$ & COST \\
\hline Peso das coxas e sobrecoxas (g) & $\operatorname{cox}$ \\
\hline Peso das asas (g) & ASA \\
\hline Peso dos pés (g) & PES \\
\hline Peso da cabeça $(g)$ & $\mathrm{CAB}$ \\
\hline Peso do coração (g) & COR \\
\hline Peso da moela (g) & MOEL \\
\hline Peso do fígado (g) & FIG \\
\hline Peso dos pulmões (g) & PULM \\
\hline Comprimento do intestino $(\mathrm{cm})$ & CINT \\
\hline Peso da gordura abdomina $(\mathrm{g}) \mid$ & GORD \\
\hline Porcentagem de carcaça & PCARC \\
\hline Porcentagem de peito & PPEIT \\
\hline Porcentagem de gordura & PGORD \\
\hline Hematócrito & HEMAT \\
\hline
\end{tabular}




\subsection{Extração do DNA genômico}

A partir de agosto de 2000 iniciou-se a extração de DNA dos primeiros animais, para testar a eficiência do protocolo de Hillel et al. (1989) e Hillel modificado, quando foram extraídos os DNAs genômicos a partir do sangue das aves parentais e alguns animais F1. O intuito foi determinar a melhor metodologia a ser utilizada em toda a pesquisa, permitindo o máximo possível de padronização, se possível com protocolo de fácil execução. O objetivo foi conseguir DNAs íntegros e em quantidades suficientes para as análises.

Posteriormente foi testado um protocolo mais simples e rápido, recomendado pelo fabricante do produto DNAzol $^{\circledR}$ (Invitrogen LIfe Technologies), que passou a ser aplicado na maioria das vezes para a extração das amostras de animais parentais, F1 e F2. Sempre que a amostra se mostrava aparentemente limpa mas a diluição do DNA não era completa, esse protocolo modificado com passos adicionais foi aplicado.

Para toda amostra cuja diluição do DNA não era completa e não se apresentava translúcida, aparentemente com resíduos proteicos, foi feita a extração utilizando proteinase $\mathrm{K}$, objetivando degradação desses resíduos; quando este protocolo resultava em DNA degradado, optava-se pelo uso de protocolo utilizando fenol. O protocolo utilizando fenol foi sempre a última opção empregada, pois com seu uso a recuperação de DNA foi sempre inferior do que com os métodos anteriores.

Todas as amostras de DNA extraídas tiveram suas concentrações avaliadas em espectrofotômetro (HITACHI, modelo U-2000) e, subseqüentemente, essas concentrações foram padronizadas para $20 \mathrm{ng} / \mu \mathrm{L}$. Após a padronização da concentração, todo as amostras DNA obtidas foram submetidas à eletroforese em gel de agarose a 1,5\%, para serem testadas quanto à sua integridade. 


\subsection{Escolha dos marcadores microssatélites}

Foram obtidos "primers" para amplificação de marcadores microssatélites posicionados nos mapas consenso, C, EL e WAU (Tabelas 4 e 5). Os "primers" empregados durante o experimento foram cedidos pela Mlchigan State University, como parte do U.S. National Animal Genome Research Program, e pelo Roslin Institute da Escócia. Foram selecionados os "primers" para marcadores posicionados nos cromossomos 3 e 5 .

Tabela 4. Marcadores microssatélites posicionados no cromossomo 3 disponíveis para o experimento

\begin{tabular}{|c|c|c|c|}
\hline Marcador $^{4}$ & $\begin{array}{l}\text { Posição no } \\
\text { mapa, cM }{ }^{1,2}\end{array}$ & $\begin{array}{l}\text { Tamanho esperado dos } \\
\text { fragmentos }(\mathrm{pb})^{3}\end{array}$ & Marcação do "primer" \\
\hline LEI 43 & $9^{1}$ & $106-120$ & TET \\
\hline MCW 169 & $31^{1}$ & 94 & HEX \\
\hline MCW 83 & $51^{1}$ & $66-93$ & HEX \\
\hline MCW 222 & $87^{2}$ & $221-225$ & FAM \\
\hline LEI 161 & $113^{2}$ & $90-100$ & HEX \\
\hline LEI 29 & $133^{2}$ & 202 & TET \\
\hline LEI 115 & $143^{1}$ & $273-292$ & HEX \\
\hline ADL 371 & $163^{2}$ & 160 & FAM \\
\hline ADL 280 & $170^{1}$ & - & FAM \\
\hline LEI 118 & $178^{1}$ & $67-91$ & FAM \\
\hline ADL 127 & $182^{1}$ & 148 & HEX \\
\hline MCW 277 & $191^{2}$ & $257-269$ & TET \\
\hline MCW 121 & $208^{2}$ & $207-212$ & HEX \\
\hline MCW 252 & $208^{2}$ & $254-296$ & TET \\
\hline MCW 224 & $218^{1}$ & $291-301$ & TET \\
\hline MCW 126 & $231^{1}$ & $129-164$ & HEX \\
\hline MCW 207 & $248^{2}$ & $278-284$ & FAM \\
\hline LEI 265 & $266^{2}$ & 290 & TET \\
\hline MCW 60 & $273^{2}$ & $206-224$ & FAM \\
\hline MCW 40 & $282^{1}$ & $135-150$ & TET \\
\hline MCW 156 & $276^{2}$ & $242-300$ & HEX \\
\hline ROS 305 & $290^{2}$ & 149 & FAM \\
\hline LEI 166 & $300^{1}$ & $254-267$ & HEX \\
\hline MCW 116 & $310^{2}$ & 287 & FAM \\
\hline MCW 37 & $317^{2}$ & $155-159$ & FAM \\
\hline
\end{tabular}


Tabela 5. Marcadores microssatélites posicionados no cromossomo 5 disponíveis para o experimento

\begin{tabular}{lccc}
\hline Marcador & $\begin{array}{c}\text { Posição no } \\
\text { mapa, cM }\end{array}$ & $\begin{array}{c}\text { Tamanho esperado dos } \\
\text { fragmentos }(\mathrm{pb})^{3}\end{array}$ & Marcação do "primer" \\
\hline LEl 116 & $6^{1}$ & $106-120$ & TET \\
MCW 263 & $28^{1}$ & $240-254$ & HEX \\
LEI 82 & $32^{1}$ & $253-280$ & HEX \\
LEl 77 & $40^{2}$ & $161-190$ & HEX \\
MCW 193 & $50^{1}$ & $302-317$ & TET \\
MCW 90 & $57^{2}$ & $221-225$ & FAM \\
MCW 214 & $80^{1}$ & $274-291$ & FAM \\
LEl 87 & $96^{2}$ & $265-304$ & HEX \\
LEI 145 & $98^{1}$ & $296-326$ & HEX \\
MCW 210 & $106^{1}$ & $153-186$ & TET \\
MCW 238 & $107^{2}$ & $187-217$ & FAM \\
ADL 239 & $113^{1}$ & 175 & HEX \\
MCW 223 & $123^{1}$ & $178-188$ & FAM \\
LEl 149 & $136^{1}$ & $160-240$ & FAM \\
ADL 233 & $151^{2}$ & 111 & FAM \\
ADL 166 & $162^{1}$ & - & FAM \\
ADL 298 & $198^{1}$ & 112 & FAM \\
& & & \\
\hline
\end{tabular}

${ }^{1}$ Posição determinada no mapa consenso. ${ }^{2}$ Posição determinada no mapa de ligação de origem (C, EL ou WAU). ${ }^{3}$ Tamanhos de fragmentos obtidos no site http://www.thearkdb.org.

${ }^{4} \mathrm{MCW}$ (Wageningen Agricultural University), LEI (University of Leicester), ADL (Avian Disease and Oncology Laboratory), ROS (Roslin Institute).

Os "primers" se apresentavam sob a forma liofilizada e foram solubilizados com Tris EDTA para uma concentração de estoque de 25 pmoles $/ \mu \mathrm{L}$. Esses estoques foram esporadicamente aliquotados para que, em diluição apropriada, pudessem ser utilizados diretamente na reação de PCR. As alíquotas foram diluídas com água milli Q, para uma concentração final de 2,5 pmoles $/ \mu \mathrm{L}$.

Em uma fase preliminar, apenas uma parte dos "primers" estava disponível, todos pertencentes aos grupos MCW e LEI. Esse material foi utilizado para amplificação das regiões microssatélites do DNA das vinte e sete aves pertencentes a geração F1. Esses indivíduos foram genotipados, detectando-se o tamanho dos fragmentos obtidos na amplificação. Dentre esses marcadores, apenas aqueles considerados informativos segundo as 
categorias apresentadas por Hillel (1997), no maior número de famílias possível, foram posteriormente amplificados e genotipados nos parentais e parte da progênie $\mathrm{F} 2$.

Com a disponibilidade do restante dos "primers", outros marcadores posicionados em regiões descobertas dos cromossomos foram amplificados diretamente nos parentais e parte dos F2. Procurou-se evitar muita proximidade ou reposição, para que houvesse um espaçamento entre marcadores próximo de 10 a 20 cM em cada cromossomo, considerando as distâncias determinadas no mapa consenso.

\subsection{Amplificação por PCR e eletroforese}

Para amplificação dos "primers" disponíveis, inicialmente foram testados os programas de temperatura e as reações de PCR apresentados no "site" http://www.genome.iastate.edu. Foram selecionados os protocolos descritos por Cheng et al. (1995) e Crooijmans (2000) para testar os "primers". Como as amplificações não se mostraram satisfatórias, foi necessário então um processo de otimização das reações de PCR, baseado nos protocolos mencionados, para determinação das quantidades dos componentes adequadas na mistura, que variaram dependendo da origem do "primer" utilizado. A amplificação ds marcadores $\mathrm{MCW}$ requereu uma quantidade maior de "primer" adicionada à reação em relação aos outros marcadores (Tabela 6).

Os ciclos de temperatura no termociclador também foram adaptados a partir das temperaturas propostas por Cheng et al. (1995) e Crooijmans (2000). (Tabela 7). Dependendo do "primer" utilizado a temperatura de anelamento variou de 50 a $59{ }^{\circ} \mathrm{C}$. Por terem sido empregados três termocicladores diferentes (MJ Research, modelos PTC-100, PTC-200 e DYAD), dependendo do aparelho utilizado a temperatura de anelamento foi aumentada em $1{ }^{\circ} \mathrm{C}$, para se obter equivalência no padrão de amplificação. 
Tabela 6. Condições das misturas para reação de PCR para todos os "primers"

\begin{tabular}{lcc}
\hline \multicolumn{1}{c}{ Componentes } & MCW & ADL, LEI, ROS \\
\hline Água milli Q & 6,2 & 7,2 \\
Tampão $(10 \mathrm{X})$ & 2,5 & 2,5 \\
,MgCl $(25 \mathrm{mM})$ & 4,0 & 4,0 \\
$\mathrm{dNTP}(10 \mathrm{mM})$ & 1,0 & 1,0 \\
"Primer" R $(2,5$ pmoles $/ \mu \mathrm{L})$ & 3,0 & 2,5 \\
"Primer" F $(2,5 \mathrm{pmoles} / \mu \mathrm{L})$ & 3,0 & 2,5 \\
Taq DNA pol. $(5 \mathrm{U} / \mu \mathrm{L})$ & 0,3 & 0,3 \\
DNA (50 -100 $\mathrm{ng} / \mu \mathrm{L})$ & 5,0 & 5,0 \\
Volume total & 25,0 & 25,0 \\
\hline
\end{tabular}

Tabela 7. Programas de temperatura da PCR para determinar o grau de informação nos F1s e para o restante das amplificações conduzidas no experimento

Programa para "primers" MCW e LEI, Programa utilizado durante o testados nos F1s experimento, para todos os "primers"
1. $95^{\circ} \mathrm{C}$, por $5^{\prime}$
1. $95^{\circ} \mathrm{C}$, por $2^{\prime}$
2. $94^{\circ} \mathrm{C}$, por30"
2. $94^{\circ} \mathrm{C}$, por30"
3. 50 a $54^{\circ} \mathrm{C}$ (MCW), por $45^{\prime \prime}$ ou
3. variando de 50 a $56{ }^{\circ} \mathrm{C}$, por $45^{\prime \prime}$
3. $55^{\circ} \mathrm{C}$ (LEI), por $45^{\prime \prime}$
4. $72{ }^{\circ} \mathrm{C}$, por l' e $30^{\prime \prime}$
4. $72^{\circ} \mathrm{C}$, por l' e $30^{\prime \prime}$
5. Repetir passos 2 ao 4,34 vezes
5. Repetir passos 2 ao 4, 34 vezes
6. $72{ }^{\circ} \mathrm{C}$, por $10^{\prime}$
6. $72{ }^{\circ} \mathrm{C}$, por $20^{\prime}$
7. $4{ }^{\circ} \mathrm{C}$, indefinidamente

7. $4{ }^{\circ} \mathrm{C}$, indefinidamente 
Todo o material foi amplificado em tubos eppendorf de $0,20 \mu \mathrm{L}$ (todos os indivíduos F1, em uma fase preliminar de seleção dos marcadores), e um terço do material amplificado em placa (parentais, F1 e F2), foram testados em gel de agarose 2,5 \% sob eletroforese, para verificação do tamanho e da intensidade das bandas obtidas, bem como o aparecimento de bandas inespecíficas. Foram aplicados $10 \mu \mathrm{l}$ de DNA amplificado e $2 \mu \mathrm{L}$ de azul de bromofenol por canaleta; $5 \mu \mathrm{L}$ do marcador de peso molecular $\varnothing \times 174$ (Promega) foi utilizado na primeira canaleta.

Quando estiveram presentes bandas inespecíficas muito intensas, as amostras foram descartadas e uma nova amplificação foi feita, com aumento de $1{ }^{\circ} \mathrm{C}$ na temperatura de anelamento; para uma pequena porção das amostras foi obtida a redução dessas bandas com a redução na concentração de $\mathrm{Mg}^{++}$ empregada na reação. O material amplificado e avaliado foi mantido em congelador a $-20{ }^{\circ} \mathrm{C}$, e descartado após genotipagem e confirmação dos resultados.

\subsection{Estratégia de genotipagem}

Em uma fase preliminar todos os segmentos amplificados a partir dos DNAs dos sete machos e vinte fêmeas F1 foram genotipados, para escolha dos marcadores informativos a serem genotipados nas aves da geração F2. A genotipagem dessa fase foi feita no seqüenciador automático ABI 377 (Applied Biossystems). No máximo três DNAs foram aplicados em conjunto por canaleta, evitando diferenças entre tamanhos de fragmentos dos marcadores inferiores a 30 pb, para amplificações cujos "primers" fossem marcados com a mesma fluorescência. Utilizou-se no preparo da solução de corrida $1,5 \mu \mathrm{L}$ de cada DNA amplificado e $10 \mu \mathrm{L}$ de tampão "loading" contendo o padrão interno TAMRA 500 (Applied Biossystems) em tubos eppendorf; no momento da aplicação os conteúdos dos tubos eram desnaturados a $95{ }^{\circ} \mathrm{C}$ por cinco minutos e mantidos em gelo até seu uso. 
As corridas foram feitas em gel de poliacrilamida desnaturante a $6 \%$, em tempo total de quatro horas. O programa computacional utilizado para calcular o tamanho dos fragmentos relativos ao padrão TAMRA-500 foi o GENESCAN (Applied Biossystems), apresentando resultados sob a forma de eletroforetogramas. As posições e áreas dos picos, contrastadas com os intervalos especificados para os alelos de cada marcador analisado, determinaram o tamanho dos fragmentos (alelos), quando submetidas ao programa GENOTYPER (Applied Biossystems).

\subsubsection{Genotipagem seletiva}

No intuito de reduzir os gastos com material e tempo, inicialmente a genotipagem foi feita de forma seletiva, utilizando todos os marcadores selecionados nos indivíduos cujos fenótipos para uma característica de eleição estavam posicionados nos extremos das curvas de distribuição normal, as quais foram determinadas para cada família originada dos casais F1.

Com exceção dos indivíduos F1 genotipados preliminarmente para identificação da informatividade dos marcadores, todas as genotipagens posteriores foram feitas em placas de noventa e seis poços, no seqüenciador capilar MEGABACE (Amersham Bioscience). Também foram utilizados no máximo três marcadores para compor cada amostra a ser aplicada. O DNA era precipitado na placa de corrida, colocando-se de 1,5 a $3 \mu \mathrm{L}$ de cada produto amplificado em cada poço e seguindo um protocolo padrão. No final da precipitação o "pool" de DNA era ressuspendido com 4,75 $\mu \mathrm{L}$ de soluçãotampão específica e $0,25 \mu \mathrm{L}$ do padrão interno ET-ROX 400 (Amersham Bioscience).

As placas precipitadas e ressuspendidas foram mantidas a $-20{ }^{\circ} \mathrm{C}$ em média por 24 horas até a aplicação, quando eram desnaturadas a $95{ }^{\circ} \mathrm{C}$ por um minuto e mantidas em gelo até serem aplicadas. As corridas tiveram tempo de duração máximo de 100 minutos, utilizando condições de injeção na pré-corrida 
de $2 \mathrm{kV}$ por 60 segundos e a corrida feita a $9 \mathrm{kV}$. O programa utilizado para representação gráfica dos picos de fluorescência e determinação do tamanho dos fragmentos foi o GENETIC PROFILER (Amersham Bioscience). Todos os eletroforetogramas e as leituras dos tamanhos dos alelos foram checados até três vezes antes de serem validados.

A porcentagem de indivíduos selecionados atendeu à conveniência da dimensão das placas de amplificação e corrida, ou seja, um valor múltiplo de noventa e seis. Pela necessidade de se manter um controle, evitando erros na genotipagem, ocasionados por migração diferenciada dos fragmentos nos diferentes capilares, tanto a amplificação quanto a genotipagem de animais F2 e parentais relacionados foi feita em uma mesma placa.

Considerando um número mínimo de indivíduos F2 e a repetição de alguns dos sete casais parentais (pois cada casal parental é comum a várias famílias), duas placas foram montadas, a primeira com cinco casais parentais e oitenta e seis descendentes F2 e a segunda com seis casais parentais e oitenta e quatro descendentes $\mathrm{F} 2$, totalizando então 170 aves $\mathrm{F} 2$. Isso representou em termos populacionais cerca de 4,5\% dos indivíduos do extremo superior e 4,5 $\%$ dos indivíduos no extremo inferior das curvas de distribuição normal, com oito indívíduos em média por família, com quantidades iguais de machos e fêmeas genotipados seletivamente.

Os marcadores genotipados nesse grupo selecionado de animais foram submetidos a um teste estatístico de independência, preliminar, para verificação de possível ligação com QTL. Considerou-se a evidência de ligação marcadorQTL significativa quando a probabilidade excedeu $\mathrm{P} \leq 0,10$.

Os marcadores selecionados foram genotipados na maior parte dos indivíduos F2 de até seis famílias selecionadas, dentre aquelas em que esses marcadores foram informativos, em uma fase posterior. Na eventualidade de menos famílias serem informativas, procurou-se genotipar um número total de aves F2 não inferior a 400, o que correspondeu a quatro famílias. Concomitantemente também foram selecionados e genotipados outros 
marcadores, alguns sabidamente informativos e outros ainda não testados, posicionados como marcadores flanqueadores.

\subsection{Determinação de heterozigozidade e PIC}

A genotipagem preliminar dos vinte casais F1 para os marcadores selecionados resultou na identificação dos alelos presentes na população para cada marcador e dos marcadores sem conteúdo de informação de polimorfismo, e também a identificação do grau de informação concedida pelo marcador dentro das famílias.

Para o cálculo foram considerados totalmente informativos os marcadores em que um dos membros do casal fosse heterozigoto e o outro possuísse um genótipo diferente (Botstein et al., 1980, citado por Zhu et al., 2001). Avaliou-se o número de alelos por marcador, o conteúdo de informação de polimorfismo (PIC) e a heterozigozidade, para dezessete marcadores posicionados no cromossomo 3 e nove marcadores no cromossomo 5, utilizando o programa CERVUS versão 2.0 (Marshall et al., 1998) (http://helios.bto.ed.ac.uk/evolgen/cervus/cervus.html).

\subsection{Procedimentos estatísticos}

\subsubsection{Ajuste de dados fenotípicos e correlações}

O primeiro procedimento estatístico aplicado durante a condução do experimento foi uma análise dos dados fenotípicos para a exclusão de valores discrepantes ("outliers") e de fenótipos de aves cujo sangue não estava disponível. Com os dados selecionados foram obtidos: médias, variâncias, desvios-padrão e coeficientes de variação para cada família F1.

Os valores referentes aos machos e fêmeas F2 foram analisados separadamente para excluir o efeito de sexo sobre as variáveis dependentes; o 
procedimento utilizado foi o GLM do pacote estatístico SAS (2001). Inicialmente foi empregado na análise um modelo incluindo como variável o efeito de incubação, para ajuste dos valores fenotípicos.

O procedimento PROC CORR foi utilizado para verificar correlações entre as características fenotípicas avaliadas, com o objetivo principal de auxiliar na escolha de uma característica de eleição, que se correlacionasse positivamente com o maior número possível de outras características. Após a escolha, os dados fenotípicos referentes a ela foram distribuídos em curvas normais, nas quais foi feita seleção dos indivíduos cujos fenótipos estavam posicionados nos extremos dessas curvas dentro de famílias, para serem genotipados em etapa preliminar.

\subsubsection{Uso do teste de qui-quadrado}

$\mathrm{Na}$ análise estatística da genotipagem seletiva, primeiramente os diversos alelos observados para cada marcador foram distribuídos entre as classes de indivíduos com fenótipos superior e inferior. As freqüências alélicas dos marcadores nos grupos fenotípicos de alto e baixo desempenho (os extremos de uma curva de distribuição normal) foram comparados por um teste simples de qui-quadrado, utilizando a seguinte equação:

$$
\chi^{2}=\sum_{i=1}^{k} \frac{\left(\mathrm{foi}_{\mathrm{i}}-\mathrm{fe}_{\mathrm{i}}\right)^{2}}{\mathrm{fe}_{\mathrm{i}}}
$$

sendo, $\mathrm{fo}_{i} \mathrm{e} \mathrm{fe}_{\mathrm{i}}$ as freqüências observada e esperada do alelo $\mathrm{i}$, de um total de $k$ alelos.

A hipótese nula $\left(\mathrm{H}_{0}\right)$ testada foi a de iguais freqüências alélicas entre os grupos. O procedimento utilizado para a análise foi o PROC FREQ do pacote estatístico SAS. Os marcadores com nível de significância menor ou igual a $10 \%$ foram considerados ligados a QTL. Por se tratar de uma varredura inicial 
de marcadores cuja ligação com QTL seria posteriormente confirmada, falsos positivos foram tolerados, desconsiderando-se uma correção para se obter o valor de significância adequado para os múltiplos testes efetuados. Esses marcadores tiveram seus genótipos reexaminados, e foram flanqueados por marcadores informativos distantes se possível não mais que $10 \mathrm{cM}$, para análises de ligação posteriores empregando teste estatístico mais estringente.

\subsubsection{Análise de Regressão}

$\mathrm{Na}$ fase de genotipagem completa, dados de todos os indivíduos pertencentes às famílias informativas, incluindo os parentais, F1 e F2, foram empregados para determinar mapas de ligação para os cromossomos 3 e 5 . Os mapas de ligação dando as distâncias precisas entre os marcadores, os genótipos desses marcadores nas famílias analisadas e os dados fenotípicos ajustados foram submetidos ao programa QTL EXPRESS (Seaton et al., 2002) (http://www.qtl.cap.ed.ac.uk).

O programa QTL Express mapeia os QTL existentes através de regressão linear (Haley et al., 1994), utilizando procedimento de duas fases: primeiramente são obtidas as probabilidades de identidade por descendência (IBD) para locos cromossômicos específicos, utilizando dados dos vários marcadores; em um segundo passo é empregado um modelo estatístico para as observações e os coeficientes IBD.

De acordo com Seaton et al. (2002), o programa QTL Express é adequado para processar dados gerados em populações F2 obtidas a partir de linhagens não endogâmicas, pois aplica um modelo linear aos dados fenotípicos, com efeitos fixos adicionais e covariáveis que expliquem variações para a característica avaliada. Os QTL podem ser especificados em termos de efeitos aditivos e dominantes; adicionalmente, para cruzamento de linhagens não endogâmicas, o modelo para QTL pode incluir um efeito inerente ao pai de origem ("imprinting"). O programa possibilita ainda que um ou mais QTL 
mapeados em um cromossomo sejam utilizados como cofatores no modelo aplicado a um outro cromossomo, reduzindo assim o "background" genético e possibilitando que um QTL de pequeno efeito seja detectado.

Antes de serem submetidos à análise estatística para avaliar a existência de QTL, os valores obtidos para as características avaliadas foram testados previamente no SAS para avaliar quais efeitos e interações influenciavam significativamente o valor dessas características. Foram também incluídas no modelo covariáveis específicas dependendo da característica: para os ganhos de peso foi colocada como covariável o peso inicial do período, sempre que a relação fosse significativa; para as características relacionadas à carcaça, com exceção daquelas calculadas como porcentagem, o peso vivo aos 42 dias foi utilizado como covariável.

Seguindo os procedimentos de comparação de modelos genéticos proposta por Knott et al. (1998), foi feita uma busca para identificar regiões nos dois cromossomos individualmente onde os marcadores pudessem explicar uma grande proporção da variância fenotípica para cada característica analisada. As regressões foram conduzidas a cada cM. O primeiro modelo testado, explicando a existência de um QTL, foi comparado com um modelo com ausência de QTL, em cada posição, sendo calculada uma razão de $F$, e obtendo-se estimativas dos efeitos aditivo e de dominância. A melhor estimativa para a posição do QTL foi a que correspondeu ao mais alto valor de $F$, sendo os valores de F obtidos através de permutações (Churchill \& Doerge, 1994).

Quando houve indício significativo $(P<0,05)$ para a presença de um $Q T L$, foram considerados modelos adicionais incluindo: (1) interações com os efeitos fixos (2) imprinting e (3) presença de dois QTL.

Para testar se o efeito do QTL foi diferente dentro de cada efeito fixo considerado, modelos com interação (1) foram individualmente testados; se significantes, foram comparados com o modelo simples para um QTL através do cálculo de $\mathrm{F}$. Se o valor de $\mathrm{F}$ foi significante, isto é, a adição da interação melhorou o modelo inicialmente significante, o mais completo foi considerado. 
Foi testado um modelo considerando efeito da origem parental do alelo (imprinting) (2) em adição aos efeitos aditivo e de dominância. Se significativo, foi comparado ao modelo simples e, quando indicou melhoria significativa, o efeito de imprinting foi considerado.

Foi testado também um modelo para a presença de dois QTL versus ausência de QTL, através de uma busca bi-dimensional. Se o modelo para 2 QTL indicou melhoria significativa ao ser comparado com o modelo para um simples QTL, então foi considerado.

Os QTL que foram significativos a $5 \%$ no cromossomo foram avaliados para a existência de ligação sugestiva e de significância no genoma, segundo a proposição de Lander \& Kruglyak (1995). Os autores recomendam que uma ligação seja considerada sugestiva quando ela representar no máximo um falso positivo em todo o genoma. No caso em que se avaliam cromossomos em separado, a probabilidade de haver um falso positivo é determinada dividindose a extensão do cromossomo analisado pela extensão da região autosômica do genoma. $\mathrm{O}$ valor de $\mathrm{F}$ referente à probabilidade encontrada é encontrado na relação de valores de $\mathrm{F}$ e probabilidades determinada a partir das 10000 permutações (Churchill \& Doerge, 1994). O valor de F referente a significância no genoma é também obtido a partir das 10000 permutações, e a probabilidade equivalente é calculada através da fórmula de correção de Bonferroni:

$$
\mathrm{P}_{\text {genoma }}=1-\left(1-\mathrm{P}_{\text {cromossomo }}\right)^{1 / r}
$$

sendo, $r$ = extensão do cromossomo dividida pela extensão do genoma autossômico.

Os intervalos de confiança a 95\% foram calculados para os QTL significativos encontrados (ao menos $5 \%$ no cromossomo), utilizando a técnica de "bootstrap" (Knott et al, 1998 e Visscher et al. 1996). 


\subsection{Determinação dos mapas de ligação}

Os marcadores da genotipagem seletiva que apresentavam ligação sugestiva com QTL na análise de qui-quadrado foram genotipados em toda a progênie $\mathrm{F} 2$ das seis famílias de casal F1 mais informativas para a mairia dos marcadores. O número de famílias completas a serem genotipadas atendeu um mínimo de 392 genótipos por marcador, chegando até um máximo de 592 aves F2, para gerar confiabilidade na avaliação das recombinações observadas.

Os genótipos dessas famílias completas para os marcadores significativos e marcadores flanqueadores dessas regiões em cada cromossomo foram submetidos ao programa CRI-MAP (Green et al., 1990), para determinação das distâncias entre os marcadores e para estabelecer mapas de ligação específicos da população para os cromossomos 3 e 5 . Em regiões onde o intervalo entre marcadores significativos era grande o suficiente para não permitir a ligação, foram inseridos marcadores não significativos porém informativos, para que a distância entre eles não fosse superior a $50 \mathrm{cM}$.

As opções empregadas no CRI-MAP foram: (1) twopoint, que determina possível ligação para cada par de marcadores, dando valores de LOD como probabilidade de ocorrência da ligação; (2) build, a qual determina ligações entre os marcadores e os ordena de acordo com a taxa de recombinação ocorrendo entre eles; (3) flips, que checa os valores de LOD enquanto vai alterando o ordenamento de cada marcador, enquanto os outros permanecem fixados; e (4) chrompic, que mostra as fases de ligação dos marcadores alinhados no cromossomo, para cada indivíduo. Para comprovação de ligação foi considerado um valor de LOD superior a 2 na opção twopoint. Quando foram indicadas duplas ou triplas recombinações nas análises do chrompic, as leituras dos genótipos foram reconferidas nos respectivos eletroferogramas. $O$ ordenamento e as distâncias dos marcadores obtidos nos mapas de ligação construídos foram comparados com o mapa consenso, para comparação de diferenças no ordenamento. 


\section{RESULTADOS E DISCUSSÃO}

\subsection{Extração do DNA e amplificação dos marcadores}

O protocolo de Hillel et al. (1989) se mostrou inadequado por ser demorado e consumir grandes quantidades de reagente e foi abandonado após as primeiras extrações; o protocolo de Hillel modificado, apesar de mais rápido, não resultou em DNA de boa qualidade. A metodologia empregando DNAzol foi de maneira geral a mais eficiente, tanto pela facilidade quanto pela rapidez do método, sendo aplicada como primeira opção para extração das amostras de aves parentais, F1 e F2.

Cerca de $10 \%$ das amostras obtidas pela extração com DNAzol resultaram em ressuspensão incompleta do DNA com presença de resíduos proteicos ou em concentração inferior a $40 \mathrm{ng} / \mu \mathrm{L}$; o procedimento nesses casos foi nova extração utilizando proteinase $\mathrm{K}$, e quando esse procedimento causou degradação do próprio DNA, foi utilizado o protocolo empregando fenol. A necessidade dos protocolos alternativos foi mais acentuada para o sangue das aves parentais, provavelmente pelo tempo de estocagem superior ao das outras amostras, e também para amostras de sangue que sofreram vários ciclos de descongelamento e recongelamento.

As amplificações por PCR foram satisfatórias para a maioria dos marcadores após os ajustes nas condições para amplificação, que determinaram quantidades adequadas nas reações e programas de temperatura apropriados para os marcadores (Tabelas 8 e 9). 
Contudo, nem todos os marcadores apresentados puderam ser utilizados no experimento, visto que alguns se mostraram informativos em um número pequeno de famílias, outros foram totalmente homozigotos na população e alguns não amplificaram posteriormente à fase inicial de identificação de marcadores informativos.

Tabela 8. Características dos marcadores microssatélites do cromossomo 3 amplificados durante o experimento

\begin{tabular}{|c|c|c|c|c|}
\hline Marcador & $\begin{array}{l}\text { Temperatura } \\
\text { anelamento } \\
\text { "primer" }\left({ }^{\circ} \mathrm{C}\right) \\
\end{array}$ & $\begin{array}{l}\text { Posição no } \\
\text { mapa, } \text { cM }^{1,2}\end{array}$ & $\begin{array}{l}\text { Alelos observados na } \\
\text { população }\end{array}$ & $\begin{array}{l}\text { Marcação } \\
\text { do "primer" }\end{array}$ \\
\hline LEI 43 & 55 & $9^{1}$ & $106,110,114,118$ & TET \\
\hline MCW 169 & 55 & $31^{1}$ & $78,90,96,100,102$ & HEX \\
\hline MCW 83 & 54 & $51^{1}$ & $82,86,88,90$ & HEX \\
\hline MCW 222 & 54 & $87^{2}$ & 221,223 & FAM \\
\hline LEI 161 & 55 & $113^{2}$ & $87,91,93$ & HEX \\
\hline LEI 29 & 59 & $133^{2}$ & $181,183,187,191$ & TET \\
\hline LEI 115 & 55 & $143^{1}$ & $274,276,292$ & HEX \\
\hline ADL 371 & 52 & $163^{2}$ & $157,164,168,172$ & FAM \\
\hline ADL 280 & 54 & $170^{1}$ & $154,156,159$ & FAM \\
\hline LEI 118 & 55 & $178^{1}$ & $70,76,82,86,90,92$ & FAM \\
\hline ADL 127 & 55 & $182^{1}$ & $145,147,149,153$ & HEX \\
\hline MCW 277 & 51 & $191^{2}$ & $256,262,268$ & TET \\
\hline MCW 121 & 54 & $208^{2}$ & 207,209 & HEX \\
\hline MCW 252 & 54 & $208^{2}$ & $254,288,292,298$ & TET \\
\hline MCW 224 & 56 & $218^{1}$ & $295,297,299,303$ & TET \\
\hline MCW 126 & 54 & $231^{1}$ & $129,161,163$ & HEX \\
\hline MCW 207 & 54 & $248^{2}$ & $280,282,284,286$ & FAM \\
\hline LEI 265 & 55 & $266^{2}$ & $\begin{array}{l}274,276,278,280,288 \\
290,292\end{array}$ & TET \\
\hline MCW 60 & 54 & $273^{2}$ & 212,222 & FAM \\
\hline MCW 40 & 55 & $282^{1}$ & $135,137,145,151$ & TET \\
\hline MCW 156 & 50 & $276^{2}$ & $\begin{array}{l}242,250,256,260,264, \\
272\end{array}$ & HEX \\
\hline ROS 305 & 56 & $290^{2}$ & $146,148,150$ & FAM \\
\hline LEI 166 & 56 & $300^{1}$ & $255,259,265$ & HEX \\
\hline MCW 116 & 55 & $310^{2}$ & 285,287 & FAM \\
\hline MCW 37 & 56 & $317^{2}$ & $173,175,183$ & FAM \\
\hline
\end{tabular}


Dentre os "primers" disponíveis, alguns não puderam ser utilizados e portanto não estão apresentados, pois ainda no período de otimização das condições de PCR, o emprego desses "primers" não resultou em amplificação, após várias tentativas.

Tabela 9. Características dos marcadores microssatélites do cromossomo 5 amplificados durante o experimento.

\begin{tabular}{ccccc}
\hline Marcador & $\begin{array}{c}\text { Temperatura } \\
\text { anelamento } \\
\text { "primer" }\left({ }^{\circ} \mathrm{C}\right)\end{array}$ & $\begin{array}{c}\text { Posição no } \\
\text { mapa, } \mathrm{cM}^{1,2}\end{array}$ & $\begin{array}{c}\text { Tamanho esperado } \\
\text { dos fragmentos }(\mathrm{pb})^{3}\end{array}$ & $\begin{array}{c}\text { Marcação } \\
\text { do "primer" }\end{array}$
\end{tabular}

\begin{tabular}{lccll}
\hline LEI 116 & 55 & $6^{1}$ & $131,135,137,145$ & TET \\
MCW 263 & 55 & $28^{1}$ & $238,243,245,251$ & HEX \\
LEI 82 & 55 & $32^{1}$ & $252,261,272,274,278$, & HEX \\
& & & 280 & \\
LEI 77 & 55 & $40^{2}$ & $306,308,310,314,318$ & HEX \\
MCW 193 & 54 & $50^{1}$ & $100,106,118,122$ & TET \\
MCW 90 & 55 & $57^{2}$ & $273,281,287,289,291$ & FAM \\
MCW 214 & 54 & $80^{1}$ & $131,135,137,145$ & FAM \\
LEI 87 & 55 & $96^{2}$ & $260,272,274,276,284$, & HEX \\
& 55 & $98^{1}$ & 290,292 & HEX \\
LEI 145 & 53 & $106^{1}$ & $157,159,161,163$ & TET \\
MCW 210 & 53 & $107^{2}$ & $185,191,197,199,201$, & FAM \\
MCW 238 & 55 & $113^{1}$ & 209 & HEX \\
ADL 239 & 55 & $123^{1}$ & $172,174,176$ & FAM \\
MCW 223 & 55 & $136^{1}$ & $212,214,216,236,234$ & FAM \\
LEI 149 & 55 & $151^{2}$ & $99,101,111,115,117$ & FAM \\
ADL 233 & $192^{1}$ & $117,119,149,151,153$ & FAM \\
ADL 166 & 57 & $101,103,105,113,117$ & FAM \\
ADL 298 & 55 & & \\
& & &
\end{tabular}

Os "primers" para os marcadores MCW 261, a 0 cM de acordo com 0 mapa consenso, e MCW 148, posicionado a 318 cM no cromossomo, foram ineficientes em gerar produtos de PCR. Também não foi possível amplificar o marcador ADL 370, mapeado no cromossomo 3 a 79 cM, mesmo depois de 
terem sido testados dois pares de "primers" disponíveis. Também foram ineficientes em gerar produtos de PCR os marcadores LEI 77, mapeado no cromossomo 5 a aproximadamente $40 \mathrm{cM}$ (posição no mapa não-consenso), e o marcador LEI 319, mapeado no cromossomo 5 a aproximadamente $67 \mathrm{cM}$ (posição estimada no mapa de ligação EL).

Alguns marcadores foram empregados satisfatoriamente durante a fase preliminar de escolha de marcadores informativos ou durante os testes de condições para amplificação, mas posteriormente se mostraram ineficientes. De forma semelhante, Zhu et al. (2001) relataram dificuldades em amplificar marcadores utilizando "primers" do Grupo 1; sugeriram que talvez o problema fosse ocasionado pelo longo tempo de estocagem desses "primers"; cerca de dois anos. Essa observação poderia parcialmente justificar a dificuldade de amplificação de alguns marcadores, pois a maioria dos "primers" utilizados no presente estudo tinham sido sintetizados ao menos dois anos antes.

As quantidades de $\mathrm{MgCl}_{2}$ empregadas neste estudo foram superiores às quantidades utilizadas em outros trabalhos, porém a tentativa de redução na maioria das vezes comprometeu a amplificação, sugerindo haver um estreito equilíbrio nas concentrações dos componentes na mistura de reação de PCR. Segundo Ferreira \& Grattapaglia (1998), altas concentrações de $\mathrm{Mg}^{++}$ maximizam a ação da polimerase durante a reação de PCR. As elevadas concentrações de $\mathrm{Mg}^{++}$empregadas neste experimento podem ter permitido que grande proporção dos marcadores disponíveis tenha sido amplificada com sucesso, comparativamente aos cerca de dois terços de marcadores do grupo 1 amplificados inicialmente por Zhu et al. (2001).

Contudo, a fidelidade da polimerase pode ser melhorada quando se obtém concentrações equimolares de $\mathrm{MgCl}_{2}$ e dNTP total, pois além dos íons $\mathrm{Mg}^{++}$serem cofator enzimático para a polimerase, uma parte deles é quelada pelo dNTP total na mistura de reação (Mc Pherson et al., 1995).

As condições de amplificação para os marcadores foram sempre verificadas, avaliando-se a presença de bandas em gel de agarose submetido 
à eletroforese, o que aparentemente demandou trabalho extra, mas certamente garantiu maior eficiência na genotipagem. A cada amplificação foi conferido se o tamanho do fragmento obtido equivalia ao esperado e observou-se a presença de bandas inespecíficas. Essas bandas quando presentes em várias posições e com forte intensidade levaram ao descarte desse material amplificado e a uma nova amplificação do marcador, utilizando temperatura de anelamento mais elevada nos ciclos de PCR.

De acordo com Mc Pherson et al. (1995), o excesso de íons $\mathrm{Mg}^{++}$pode estabilizar o anelamento inespecífico do primer em sítios incorretos, resultando em grandes quantidades de produtos indesejáveis. A redução na quantidade de $\mathrm{MgCl}_{2}$ efetuada durante os ajustes de protocolo de amplificação objetivando aumentar a especificidade do "primer" surtiu pouco efeito quando comparada ao ajuste na temperatura.

Quando foi constatada a presença de banda inespecífica pouco intensa, essa amplificação foi aproveitada sendo corrida no seqüenciador automático compondo amostra sempre com amplificações marcadas com fluorescência diferente, evitando assim qualquer tipo de confundimento entre bandas inespecíficas de um marcador e fragmentos de outro de mesma fluorescência, pois outras bandas não visíveis no gel de agarose poderiam estar presentes. $\mathrm{O}$ uso da técnica de "touchdown" no programa de temperatura da PCR, descrito por McPherson \& Hames (1995) e utilizado por Zhu et al. (2001), permitindo a amplificação eficiente de marcadores que falharam em seu experimento, não foi testado no presente estudo.

\subsection{Marcadores informativos, heterozigozidade e PIC}

Foram amplificados dezessete marcadores do cromossomo 3 e 10 marcadores do cromossomo 5, pertencentes ao Grupo 1, para determinar quais eram informativos nos casais F1 (Tabela 10); estes foram posteriormente genotipados nos indivíduos F2. Dentre os marcadores avaliados, alguns foram 
prontamente descartados. O marcador LEI 44 apresentou apenas um alelo, portanto ocorrendo em homozigose em todos os indivíduos F1. Os marcadores MCW 121 e MCW 148, no cromossomo 3, e MCW 223, no cromossomo 5, foram homozigotos em dezenove das vinte famílias.

Tabela 10. Marcadores nos cromossomos 3 e 5, por ordem de posicionamento, informativos nas famílias geradas a partir de vinte casais F1

\begin{tabular}{|c|c|c|c|}
\hline $\begin{array}{l}\text { Marcadores do } \\
\text { cromossomo } 3 \\
\text { (cM) }\end{array}$ & $\begin{array}{l}\mathrm{N}{ }^{0} \text { de casais } \\
\text { informativos } \\
\text { (alelos obs.) }\end{array}$ & $\begin{array}{c}\text { Marcadores do } \\
\text { cromossomo } 5 \\
\text { (cM) }\end{array}$ & $\begin{array}{l}\mathrm{N}^{0} \text { de casais } \\
\text { informativos } \\
\text { (alelos obs.) }\end{array}$ \\
\hline LEI 43 (9) & $4(4)$ & MCW 263 (28) & $12(4)$ \\
\hline MCW 83 (51) & $4(4)$ & LEI 82 (32) & $18(6)$ \\
\hline MCW 222 (87) & $6(2)$ & MCW 193 (50) & $17(4)$ \\
\hline LEI 161 (113) & $9(3)$ & MCW 214 (80) & $19(7)$ \\
\hline LEI 115 (143) & $7(3)$ & LEI 87 (96) & $15(7)$ \\
\hline LEI 118 (178) & $15(6)$ & LEI 145 (98) & $15(5)$ \\
\hline MCW 277 (191) & $10(3)$ & MCW 210 (106) & $14(4)$ \\
\hline MCW 93 (194) & $7(4)$ & MCW 238 (107) & $15(6)$ \\
\hline MCW 252 (208) & $15(5)$ & MCW 223 (123) & $2(2)$ \\
\hline MCW 121 (208) & $6(2)$ & LEI 149 (136) & $15(5)$ \\
\hline MCW 224 (218) & $13(4)$ & & \\
\hline MCW 126 (231) & $9(3)$ & & \\
\hline MCW 207 (248) & $14(4)$ & & \\
\hline MCW 156 (276) & $4(6)$ & & \\
\hline MCW 40 (282) & $14(4)$ & & \\
\hline LEI 166 (300) & $10(3)$ & & \\
\hline MCW 148 (318) & $1(2)$ & & \\
\hline
\end{tabular}

Quando marcadores próximos foram ambos informativos, como no caso dos marcadores LEI 87 e LEI 145 no cromossomo 5, apenas um foi selecionado para amplificações posteriores nos indivíduos parentais e F2, sendo o critério de escolha a quantidade de informação em um maior número de famílias dentre os vinte casais avaliados, ou que possuísse melhor qualidade na amplificação; o marcador selecionado foi o LEI 145 pela dificuldade de amplificação do LEI 87. 
O número de alelos obtidos para cada marcador foi empregado para cálculo de heterozigozidade e PIC utilizando o programa CERVUS (Marshall et al., 1998). A avaliação dos alelos dos dezessete marcadores amplificados no cromossomo 3 determinou valores para heterozigosidade, PIC, e número médio de alelos por marcador, de 0,57, 0,51 e 4,71, respectivamente. Os nove marcadores analisados no cromossomo 5 resultaram em valores de heterozigosidade, PIC e número médio de alelos por marcador de 0,72, 0,66 e 6,89 , respectivamente.

Os valores encontrados são superiores aos obtidos por Crooijmans et al. (1996), de 0,53 e 3,6 para heterozigosidade estimada e número médio de alelos em frangos, respectivamente, e por Zhu et al. (2001), avaliando vinte e sete marcadores microssatélites em frangos, de 0,52, 0,45 e 3,5 para heterozigosidade estimada, PIC e número médio de alelos, respectivamente. Dados apresentados por Baron et al. (2001) registram valores de 0,51, 0,65, 0,67 de PIC e 0,59, 0,70, 0,73 de heterozigozidade, para os cromossomos 1,2 e 4 respectivamente, calculados para 27 aves F1 na mesma população empregada neste estudo.

Tanto Crooijmans et al. (1996) quanto Zhu et al. (2001) afirmaram que o polimorfismo reduzido observado em frangos em relação a outros animais produtores de carne está relacionado à perda de diversidade genética devido ao longo tempo de seleção ocorrendo nas linhagens comerciais de aves.

Considerando que os indivíduos avaliados em nosso experimento representativos dos genótipos do cruzamento TC, e que o polimorfismo foi elevado quando comparado a outros experimentos, aparentemente ficou comprovado que a seleção aplicada às linhagens formadoras foi diferenciada o suficiente para garantir grande divergência a nossa população, atendendo ao requisito inicial de uma população desenvolvida para o mapeamento de QTL. 


\subsection{Análise estatística dos dados fenotípicos}

As aves da geração F2 foram avaliadas para vinte e oito características, medidas ou inferidas, referentes ao desempenho no crescimento e à qualidade de carcaça. Ao todo foram obtidos dados referentes a 2063 indivíduos F2 originados do cruzamento TC (machos de corte acasalados com fêmeas de postura). Foram descartados dados de 108 animais cujo sangue da mãe F1 não estava disponível, restando então 20 famílias TC de irmãos completos. Também foram eliminadas 8 medidas que variaram mais de quatro desviospadrão da média de cada característica, consideradas "outliers" verdadeiros ou erros de anotação.

Os outliers foram distribuídos ao acaso entre as vinte famílias, indicando que não houve componente genético envolvido. Restaram valores fenotípicos de 1860 aves, medidos em 925 fêmeas e 934 machos, para serem analisados estatisticamente.

Através do PROC MEANS do SAS (2000) foram determinadas médias e desvios-padrão para as características fenotípicas avaliadas na geração F2 do cruzamento TC (Tabela 11). As correlações entre as variáveis foram obtidas pelo PROC CORR (Tabelas 12 e 12), para permitir a escolha de uma única característica a ser empregada como critério de seleção dos primeiros indivíduos F2 a serem genotipados.

Dentre várias características correlacionadas, o PV42 foi escolhido como variável de eleição para selecionar os animais utilizados na genotipagem seletiva, uma vez que é a que apresenta maior correlação geral com as demais, não é uma medida parcial, além de ser uma das características principais consideradas na seleção de frangos de corte.

Os dados referentes ao PV42 foram submetidos ao procedimento GLM do SAS. Foi escolhido a princípio um modelo incluindo pai, mãe, incubação e sexo, para testar a existência de efeitos significativos sobre os fenótipos, 
considerando os valores de probabilidade de $\mathrm{H}_{0}$ dados pela soma de quadrados tipo III, indicada para análise de dados desbalanceados.

Tabela 11. Médias, desvios-padrão, valores máximos e mínimos para características de desempenho e carcaça de 1860 aves F2

\begin{tabular}{|c|c|c|c|c|}
\hline Variável $^{1}$ & Média & Desvio-padrão & Valor máximo & Valor mínimo \\
\hline PV42 & 987,29 & 183,70 & 526,00 & 1631,00 \\
\hline PN & 45,92 & 4,56 & 15,60 & 78,70 \\
\hline PV35 & 802,07 & 136,60 & 490,00 & 1309,00 \\
\hline PV41 & 1023,09 & 184,38 & 550,00 & 1686,00 \\
\hline GPN35 & 756,15 & 135,95 & 448,60 & 1259,10 \\
\hline GPN41 & 977,17 & 183,48 & 471,30 & 1636,10 \\
\hline GPN42 & 941,37 & 182,87 & 447,30 & 1582,20 \\
\hline GP35-41 & 223,76 & 66,89 & 36,00 & 411,00 \\
\hline $\mathrm{CR}$ & 602,64 & 138,46 & 124,00 & 1176,00 \\
\hline CA & 2,83 & 0,75 & 0,83 & 8,20 \\
\hline EF & 0,37 & 0,07 & 0,05 & 0,66 \\
\hline $\mathrm{CAB}$ & 34,80 & 5,93 & 21,00 & 55,00 \\
\hline PES & 40,39 & 9,01 & 23,00 & 73,00 \\
\hline FIG & 26,60 & 5,16 & 15,00 & 49,00 \\
\hline COR & 6,59 & 1,61 & 2,00 & 12,00 \\
\hline MOEL & 24,61 & 4,91 & 13,00 & 43,00 \\
\hline CINT & 153,84 & 15,10 & 112,00 & 212,00 \\
\hline ASA & 80,73 & 14,24 & 31,00 & 127,00 \\
\hline COXA & 211,95 & 44,67 & 102,00 & 354,00 \\
\hline PEIT & 158,45 & 34,10 & 70,00 & 350,00 \\
\hline COST & 188,55 & 39,49 & 92,00 & 334,00 \\
\hline PULM & 8,21 & 2,26 & 3,00 & 16,00 \\
\hline GORD & 16,66 & 8,15 & 0,00 & 53,00 \\
\hline CARC & 639,67 & 128,45 & 309,00 & 1145,00 \\
\hline PCARC & 64,64 & 2,10 & 55,54 & 75,34 \\
\hline PPEIT & 16,00 & 1,15 & 12,18 & 22,88 \\
\hline PGORD & 1,64 & 0,67 & 0,00 & 4,47 \\
\hline HEMAT & 28,21 & 3,18 & 16,00 & 44,00 \\
\hline \multicolumn{5}{|c|}{ 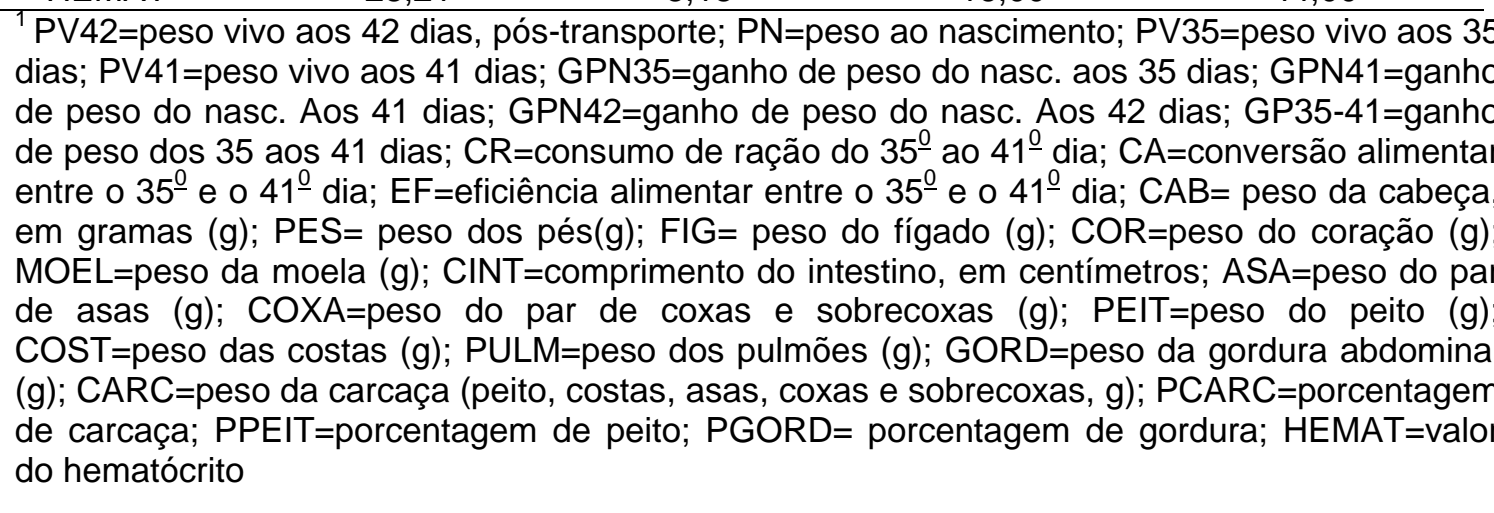 } \\
\hline
\end{tabular}


Tabela 12. Correlações entre algumas características de desempenho, medidas em 566 aves F2 do cruzamento TC

\begin{tabular}{lcccccccccc}
\hline \multicolumn{2}{l}{ Variável $^{1}$} & $(1)$ & $(2)$ & $(3)$ & $(4)$ & $(5)$ & $(6)$ & $(7)$ & $(8)$ & $(9)$ \\
PV42 & $(1)$ & 1,00 & 0,07 & 0,86 & 0,99 & 0,66 & 0,86 & 0,99 & 0,59 & $-0,09$ \\
PN & $(2)$ & & 1,00 & 0,07 & 0,07 & 0,03 & 0,05 & 0,05 & 0,05 & 0,05 \\
PV35 & $(3)$ & & & 1,00 & 0,86 & 0,38 & 1,00 & 0,86 & 0,48 & 0,01 \\
PV41 & $(4)$ & & & & 1,00 & 0,70 & 0,86 & 1,00 & 0,60 & $-0,11$ \\
GP35-41 (5) & & & & & 1,00 & 0,38 & 0,70 & 0,59 & $-0,32$ \\
GPN35 & $(6)$ & & & & & & 1,00 & 0,86 & 0,48 & 0,01 \\
GPN41 & $(7)$ & & & & & & & 1,00 & 0,60 & $-0,11$ \\
CR35-41 (8) & & & & & & & & 1,00 & $-0,04$ \\
CA & $(9)$ & & & & & & & & & 1,00 \\
\hline
\end{tabular}

${ }^{1}$ PV42=peso vivo aos 42 dias, pós-transporte; PN=peso ao nascimento; PV35=peso vivo aos 35 dias; PV41=peso vivo aos 41 dias; GPN35=ganho de peso do nasc. aos 35 dias; GPN41=ganho de peso do nasc. Aos 41 dias; GPN42=ganho de peso do nasc. Aos 42 dias; GP35-41=ganho de peso dos 35 aos 41 dias; $C R=$ consumo de ração do $35^{\circ}$ ao $41^{0}$ dia; $C A=$ conversão alimentar entre o $35^{\circ}$ e o $41^{0}$ dia; $E F=$ eficiência alimentar entre o $35^{\circ}$ e o $41^{\circ}$ dia

Tabela 13. Correlações entre algumas características de carcaça e PV42, medidas em 566 aves F2 do cruzamento TC

\begin{tabular}{|c|c|c|c|c|c|c|c|c|c|}
\hline Variável & (1) & $(2)$ & (3) & (4) & (5) & (6) & (7) & (8) & (9) \\
\hline PV42 (1) & 1,00 & 0,84 & 0,42 & 0,61 & 0,40 & 0,79 & 0,87 & 0,80 & 0,48 \\
\hline CARC (2) & & 1,00 & 0,48 & 0,61 & 0,33 & 0,95 & 0,91 & 0,94 & 0,55 \\
\hline PCARC (3) & & & 1,00 & 0,25 & 0,18 & 0,48 & 0,49 & 0,41 & 0,26 \\
\hline GORD (4) & & & & 1,00 & 0,87 & 0,53 & 0,62 & 0,50 & 0,33 \\
\hline PGORD (5) & & & & & 1,00 & 0,27 & 0,34 & 0,23 & 0,17 \\
\hline PEIT (6) & & & & & & 1,00 & 0,83 & 0,88 & 0,51 \\
\hline COXA (7) & & & & & & & 1,00 & 0,85 & 0,50 \\
\hline ASA (8) & & & & & & & & 1,00 & 0,52 \\
\hline COR (9) & & & & & & & & & 1,00 \\
\hline
\end{tabular}


Comprovados efeitos de pai, incubação e sexo $(P<0,001)$, optou-se por separar machos e fêmeas em arquivos distintos para excluir o efeito de sexo. Os dados foram ajustados apenas para incubação (PV42ajust); não houve correção para efeitos de pai e mãe, para que as diferenças fenotípicas não fossem reduzidas a ponto de dificultar a detecção da variabilidade quantitativa dos dados.

A escolha das aves a serem genotipadas seletivamente foi feita dentro das famílias de mães $F 1$, seguindo recomendação de Hillel (1997) para cruzamento entre linhagens comerciais de aves, tipicamente não endogâmicas. Segundo Muranty et al. (1997), nesse tipo de cruzamento se a seleção de animais a serem genotipados for feita nos extremos da população, todos os indivíduos de determinadas famílias poderiam ser escolhidos e de outras nenhum poderia ser escolhido, devido ao efeito de família. De acordo com os autores, a variação quantitativa que está em desequilíbrio de ligação com os marcadores, devido aos indivíduos serem originados de cruzamentos controlados, é essencialmente a variação genotípica dentro de família, consequentemente na genotipagem seletiva a escolha dos indivíduos deve ser feita nos extremos da curva de ditribuição de cada família.

\subsection{Genotipagem seletiva}

Os marcadores selecionados como informativos nos animais F1 foram genotipados em uma parcela dos indívíduos F2, obtida a partir da curva de distribuição normal para a variável PV42ajust feita nas famílias. Foram selecionados os extremos da curva, ou seja, ou seja, os 4,5\% de indivíduos mais pesados e os $4,5 \%$ mais leves dentro de cada família, variando entre seis a 10 aves dependendo do número de filhos para cada casal F1. Outras variáveis mostraram correlação positiva com a variável de escolha, o que permitiria, conforme afirmaram Muranty \& Goffinet (1997) e Bovenhuis \& 
Spelman (2000), a detecção de QTL para essas características com alguma redução no poder de teste. Foram selecionados os extremos da curva,

No intuito de reduzir o espaçamento entre os marcadores inicialmente selecionados, marcadores adicionais foram genotipados; esses marcadores não haviam sido testados previamente para grau de informação, e a seleção foi feita pelo posicionamento e facilidade de amplificar amostras de DNA teste. No cromossomo 3 a genotipagem seletiva utilizou dezenove marcadores informativos, sendo que o espaçamento médio entre eles, de acordo com os posicionamentos estimados no mapa consenso, foi de 16,7 cM, com o maior intervalo sendo de $36 \mathrm{cM}$ e o menor de $3 \mathrm{cM}$, e uma cobertura estimada de até $341 \mathrm{cM}$, supondo que os marcadores posicionados nos extremos estariam cobrindo até $20 \mathrm{cM}$ para cada um dos lados.

No cromossomo 5 a genotipagem seletiva foi feita para onze marcadores, sendo que o espaçamento médio entre eles foi de $21,3 \mathrm{cM}$, sendo o maior intervalo de $47 \mathrm{cM}$ e o menor de $4 \mathrm{cM}$, com cobertura estimada de 222 cM. A maior distância presente entre marcadores ficou localizada no final do cromossomo 5, entre ADL 233 e ADL 298. O único marcador disponível nessa região, ADL166, ainda manteria um espaçamento superior a $30 \mathrm{cM}$ (Groenen et al., 2000). Esse marcador não foi polimórfico na população TC.

O número de alelos observados para cada marcador dentro dos grupos de leves e pesados foi comparado através do teste de qui-quadrado. Como essa análise estatística para detecção de ligação do marcador com um QTL foi apenas um passo inicial indicativo de prováveis QTL, foram considerados níveis de significância de até $10 \%$ (Figuras 1 e 2). Os vários testes efetuados aumentaram a chance de ocorrência de falsos positivos. Esses falsos positivos deveriam ser descartados posteriormente, quando se aplicaria um teste mais estringente utilizando os genótipos e fenótipos de ao menos 90 aves F2 de cada família. 
Os posicionamentos considerados na análise estatística para a genotipagem seletiva foram os apresentados no mapa consenso 2000 (Groenen et al., 2000) para os marcadores LEI 43, MCW 169, LEI 118, ADL 127 e MCW 116 no cromossomo 3 e MCW 193, MCW 90, LEI 145 e ADL 298 no cromossomo 5; os marcadores restantes no dois cromossomos foram posicionados de acordo com seus mapas de origem. Foram observadas quatro regiões no cromossomo 3 onde se concentraram marcadores indicando ligações significativas com QTL para PV42 ajustado.

A primeira região é representada pelo LEI $43(\mathrm{P}=0,071)$ e MCW 169 $(\mathrm{P}=0,035)$, posicionados a 9 e $31 \mathrm{cM}$, respectivamente (posições dadas no mapa consenso). A região próxima ao marcador MCW 169 coincidiu a posição descrita por McElroy et al. (2002) possuindo QTL para peso corporal às seis semanas de idade, pós-transporte para abate.

A segunda região abrange os marcadores MCW $222(P=0,001)$ e LEI 161 $(P=0,009)$, posicionados a 87 e $113 \mathrm{cM}$, respectivamente.

A terceira região observada no cromossomo 3 apresentou três marcadores muito próximos, LEl $118(P=0,006)$, ADL $127(P=0,039)$ e MCW $277(\mathrm{P}=0,024)$, localizados a 178, 182 e $191 \mathrm{cM}$, respectivamente. Não foram identificados QTL para peso vivo anteriormente nessa região, contudo um QTL para "escore" de conformação foi mapeado por McElroy et al. (2002) a 188 cM.

Tuiskula-Haavisto et al (2002), em experimento empregando população desenvolvida a partir de linhagens poedeiras, encontraram um QTL significativo para idade ao primeiro ovo na região entre 153 a 201 cM. Não obstante essa característica não ter sido avaliada neste estudo, ela é positivamente correlacionada com PV em aves poedeiras.

McElroy et al. (2002) detectaram QTL significativos para PV ao abate e para pesos de meia carcaça, carne branca e fillet, localizados a $154 \mathrm{cM}$ no cromossomo 3. Apesar de existirem dois marcadores informativos nessa região, LEI 115 a 143 cM e ADL 371 a 163 cM, eles não foram significativamente ou 
sugestivamente ligados a QTL e, ao menos nessa análise preliminar da genotipagem seletiva, esses QTL reportados não foram confirmados.

A quarta região foi relacionada ao marcador MCW 116 ( $P=0,005)$, localizado a 310 cM. Apesar de não haver descrição prévia de QTL significativos ou sugestivos nessa posição, Van Kaam (1999b) apontaram a região posicionada entre os marcadores Lei 166 e MCW 116 como potencial para identificação de QTL para PV48 e para peso de carcaça.

Foram localizadas três regiões no cromossomo 5 onde houve significância na ligação entre marcadores e QTL. A primeira região possui os marcadores MCW $193(P=0,067)$ e MCW $90(P=0,001)$ a 50 e $57 \mathrm{cM}$, respectivamente. McElroy et al. (2002) encontraram ligação do marcador MCW 193 com QTL, sugestiva a $10 \%$, para nove características distintas, inclusive $P V$ às seis semanas pré e pós-transporte. Entretanto esses autores empregaram apenas esse marcador em todo o cromossomo 5, em análise de marca simples, e a detecção de ligações marcador-QTL em níveis significativos depende, entre outros fatores, da distância e grau de informação dos marcadores.

Tuiskula-Haavisto et al. (2002), avaliando população de poedeiras, encontraram um QTL significativo para gravidade específica do ovo localizado entre 32 e 112 cM no cromossomo 5; entretanto não foi possível estabelecer relação entre essa característica e outras avaliadas no presente trabalho.

A outras duas regiões sugestivamente ligadas a QTL para PV42 no cromossomo 5 foram localizadas a $151 \mathrm{cM}$, onde está posicionado o marcador ADL $233(P=0,071)$, e a $198 \mathrm{cM}$, a mesma posicão do marcador ADL $298(P=$ 0,037). Não há menção prévia de QTL para desempenho e qualidade de carcaça nessas duas regiões, contudo o marcador ADL 298 já foi associado à resposta imune, em experimento conduzido por Yonash et al. (2001). 


\subsection{Construção dos mapas de ligação}

Para a construção dos mapas de ligação para os cromossomos 3 e 5 foram genotipadas as progênies F2 completas das seis famílias mais informativas para os marcadores que apresentaram relação com QTL para PV42ajust na genotipagem seletiva. O marcador MCW 116 no cromossomo 3 foi uma exceção, pois apesar de ter sido associado a QTL, apresentou variação alélica em apenas duas famílias, descendentes de um mesmo parental. Marcadores não significativos porém informativos foram também genotipados para famílias F2 completas, para permitir um distanciamento regular e não superior a $30 \mathrm{cM}$ (Tabela 14).

Marcadores adicionais foram obtidos do Roslin Institute na fase final do experimento; aqueles que, de acordo com o mapa consenso, estavam posicionados nas lacunas não cobertas pelos marcadores disponíveis, foram genotipados nos parentais e F1, contudo se mostraram homozigotos ou muito pouco informativos na população em estudo, sendo seu uso descartado. No total 13 marcadores foram genotipados para o cromossomo 3 e sete para o cromossomo 5.

Para se obter uma quantidade de meioses informativas que representasse adequadamente as taxas de recombinação, pois com poucos animais esta pode ocorrer de forma tendenciosa, foram selecionadas até seis famílias obtidas dos casais $\mathrm{F} 1 \mathrm{e}$, mesmo em casos onde o marcador não era informativo para alguma família selecionada, ainda assim no mínimo quatro famílias foram genotipadas. Houve preferência pela seleção de famílias aparentadas próximas, ou seja, que o macho F1 fosse comum, obtendo-se assim um grande número de meios-irmãos.

Os dados genotípicos tabulados foram submetidos ao programa CRIMAP, para confirmação de ligação, ordenamento e posicionamento dos marcadores, permitindo posteriormente determinar mais precisamente o posicionamento de possíveis QTL. Os mapas de ligação obtidos para os dois 
cromossomos permitiram também uma análise comparativa com o mapa consenso.

Tabela 14. Marcadores utilizados para construção do mapa de ligação, famílias empregadas e número de aves F2 genotipadas por marcador

\begin{tabular}{|c|c|c|}
\hline $\begin{array}{c}\text { Marcadores no } \\
\text { Cromossomo } 3\left(\mathrm{P}^{*}\right)^{1}\end{array}$ & $\begin{array}{l}\text { Famílias genotipadas } \\
\text { (número da mãe F1) }\end{array}$ & $\begin{array}{l}\text { Total de F2 } \\
\text { genotipados }^{3}\end{array}$ \\
\hline LEI $43(P=0,071)$ & $7810,7978,7812,7972$ & 396 \\
\hline MCW $169(P=0,035)$ & $7810,7978,7765,7971,7812,7972$ & 592 \\
\hline MCW $222(P=0,001)$ & $7810,7978,7765,7971,7972$ & 494 \\
\hline LEI $161(P=0,009)$ & $7810,7978,7765,7971,7812,7972$ & 592 \\
\hline LEI $29^{2}$ & $7810,7978,7765,7971,7812,7972$ & 592 \\
\hline ADL $371(P=0,20)^{4}$ & $7978,7765,7971,7812,7972$ & 494 \\
\hline LEI $118(\mathrm{P}=0,006)$ & $7810,7978,7765,7971,7972,7812$ & 592 \\
\hline ADL $127(P=0,039)$ & $7810,7978,7765,7971,7972,7812$ & 592 \\
\hline MCW $277(P=0,024)$ & $7810,7978,7765,7971,7812$ & 492 \\
\hline MCW224 $(P=0,773)^{4}$ & $7810,7978,7765,7971,7812,7972$ & 592 \\
\hline MCW $207(P=0,95)^{4}$ & $7810,7978,7765,7971,7812,7972$ & 592 \\
\hline MCW $40(P=0,524)^{4}$ & $7810,7978,7765,7971,7812,7972$ & 592 \\
\hline LEI $166(P=0,782)^{4}$ & $7810,7978,7765,7971,7812,7972$ & 592 \\
\hline \multicolumn{3}{|l|}{$\begin{array}{c}\text { Marcadores no } \\
\text { Cromossomo } 5(P=*)^{1}\end{array}$} \\
\hline LEI $82(P=0,882)^{4}$ & $7810,7978,7765,7971,7812,7972$ & 592 \\
\hline MCW $193(P=0,067)$ & $7810,7978,7765,7971,7812,7972$ & 592 \\
\hline MCW $90(P=0,001)$ & $7810,7978,7765,7971,7812,7972$ & 592 \\
\hline LEI $145(P=0,197)^{4}$ & $7810,7978,7765,7971,7812,7972$ & 592 \\
\hline LEI 149 & $7810,7978,7765,7971,7972$ & 494 \\
\hline ADL $233(P=0,071)$ & $7810,7978,7765,7971,7812,7972$ & 592 \\
\hline ADL $298(P=0,037)$ & $7810,7978,7765,7971,7812,7972$ & 592 \\
\hline
\end{tabular}

As análises para a construção dos mapas de ligação foram feitas individualmente para cada cromossomo, com seus respectivos marcadores. Como procedimento geral, inicialmente foi empregada a opção twopoint 
utilizando para descarte de ordenamento um valor de tolerância de 2, isto é, só foram consideradas as ligações entre pares de marcadores com valor de LOD iguais ou maiores que 2. A opção build foi empregada em seguida para ordenamento de todos os marcadores do cromossomo, utilizando-se como ordem inicial um par de marcadores ligados e altamente informativos selecionados previamente no twopoint. Os outros marcadores foram inseridos um a um até que todos estivessem posicionados. Os mapas finais apresentados na opção build, para machos, fêmeas e para ambos os sexos, indicam as taxas de recombinação encontradas e as posições dos marcadores calculadas usando a função de mapeamento de Kosambi.

O passo de verificação chrompic também foi utilizado para indicar as fases de ligação de cada marcador ordenado no cromossomo para cada indivíduo; sempre que era constatada a presença de dupla ou tripla recombinação, a leitura do genótipo obtida no programa GENETIC PROFILER foi reconferida. O ordenamento dos locos obtido pelo build foi checado utilizando-se a opção flipsn, que executou permutações de ordenamento a cada 3 locos adjacentes, sendo considerada com ordem correta a de maior LOD.

Para construir um mapa de ligação para o cromossomo 3 foram utilizados genótipos para os marcadores LEI 43, MCW 169, MCW 222, LEI 161, LEI 29, ADL 371, LEI 118, ADL 127, MCW 277, MCW 224, MCW 207, MCW 40 e LEI 166. O marcador LEI 43 não foi informativo para duas das seis famílias escolhidas, sendo genotipado em 392 aves F2; os marcadores MCW 222, ADL 371 e MCW 277 foram informativos em cinco das seis famílias, sendo genotipados em 494 aves F2. Os marcadores restantes foram genotipados em 592 aves, distribuídas nas seis famílias escolhidas (Figura 3).

$\mathrm{Na}$ construção do mapa de ligação do cromossomo 3 não foi possível inserir todos os marcadores utilizando-se conjuntamente os dados das seis famílias. Foram construídos então três mapas distintos, cada um com duas famílias cujo macho F1 fosse comum; as distâncias entre locos estimadas nestes três mapas variaram pouco e não houve diferenças quanto ao 
ordenamento, sendo considerado no mapa final um valor médio entre os três mapas obtidos para a posição de cada marcador.

\begin{tabular}{|c|c|c|c|}
\hline \multicolumn{4}{|c|}{ CROMOSSOMO 3} \\
\hline \multicolumn{4}{|c|}{ (mapa intermediário para os dois sexos) } \\
\hline Marcador & $\begin{array}{c}\text { taxas de } \\
\text { recombinação } \\
\text { observadas }\end{array}$ & $\begin{array}{l}\text { Posições } \\
\text { estimadas } \\
\text { (cM) }\end{array}$ & $\begin{array}{l}\text { Pos. estimada no } \\
\text { mapa consenso } \\
\text { (cM) }\end{array}$ \\
\hline LEI 43 & & $9,0^{1}$ & 9,0 \\
\hline | & 0,19 & & \\
\hline MCW 169 & & 29,0 & 31,0 \\
\hline $\begin{array}{l}\mid \\
\text { MCW } 222\end{array}$ & 0,42 & & $877^{2}$ \\
\hline Mew 222 & 0,22 & 93,0 & $81, r^{2}$ \\
\hline LEI 161 & & 117,0 & $113,6^{2}$ \\
\hline 1 & 0,02 & & \\
\hline LEI 29 & & 120,4 & $133,8^{2}$ \\
\hline 1 & 0,22 & & \\
\hline ADL 371 & & 144,4 & $163,5^{2}$ \\
\hline | & 0,27 & & \\
\hline LEI 118 & & 172,4 & 178,0 \\
\hline MCW 277 & 0,01 & 174,5 & $191,3^{2}$ \\
\hline & 0,01 & & \\
\hline ADL 127 & & 177,1 & 182,0 \\
\hline & 0,27 & & \\
\hline MCW 224 & & 207,1 & 218,0 \\
\hline 1 & 0,18 & & \\
\hline MCW 207 & & 226,1 & $248,2^{2}$ \\
\hline | & 0,26 & & \\
\hline MCW 40 & & 255,0 & 282,0 \\
\hline | & 0,25 & & \\
\hline LEI 166 & & 282,0 & 300,0 \\
\hline
\end{tabular}

Figura 3 - Mapa de ligação do cromossomo 3, para o cruzamento TC 
Alguns marcadores empregados não estão posicionados no mapa consenso, e suas posições foram checadas conferindo-se o posicionamento em seus mapas de origem em relação a outras marcas presentes nesses mapas e no mapa consenso, as quais foram genotipadas neste experimento. Os marcadores LEI 29 e ADL 371 foram mapeados apenas na população EL; suas posicões puderam ser estimadas quando comparadas suas distâncias com os marcadores flanqueadores MCW 169, mapeado nas populações EL, WAU e no mapa consenso e ADL 127, mapeado nas populações EL, WAU, C e no mapa consenso.

Os marcadores MCW 222, MCW 277 e MCW 207 foram mapeados apenas na população WAU, e também tiveram seus posicionamentos checados em relação a marcadores flanqueadores posicionados nessa população e no mapa consenso.

A ordem dos marcadores LEI 118 - MCW 277 - ADL 127 foi diferente da ordem LEI 118 - ADL 127 - MCW 277 publicada para machos e para os dois sexos na população WAU (http://www.thearkdb.org/browser), porém nessa mesma população o mapa específico para fêmeas apresenta os marcadores ADL 127 e MCW 277 na mesma ordem encontrada no presente estudo. Considerando que esses marcadores estão muito próximos e portanto apresentam pequenas taxas de recombinação entre si, fatores como número de animais genotipados e quantidade de informação dos marcadores podem influenciar tendenciosamente as taxas de recombinação, mudando o posicionamento dos locos.

O comprimento total do mapa obtido para a população em estudo foi de $273 \mathrm{cM}$, considerando para o primeiro marcador, LEI 43, a posição dada no mapa consenso, de $9 \mathrm{cM}$. O Comprimento total foi inferior ao do mapa consenso, de $291 \mathrm{cM}$, mas diferenças com amplitude equivalente também ocorreram quando comparados o mapa consenso e os mapas das populações referência EL, C e WAU. 
A distância média entre marcadores no cromossomo 3 foi de 22,75 cM pouco além do intervalo mínimo desejado de $20 \mathrm{cM}$. O menor intervalo foi de 2,1 cM, entre os marcadores LEI 118 e MCW 277. O maior intervalo foi de 64 cM, entre os marcadores MCW 169 e MCW 222. Não obstante a procura por marcadores informativos que pudessem reduzir esse intervalo, nenhum marcador cujos "primers" estavam disponíveis atendeu a esta necessidade.

As diferenças observadas das distâncias entre locos em relação ao mapa consenso e outras populações-referências mapeadas eram esperadas, dada a diversidade das populações mapeadas. Os marcadores empregados neste experimento apresentaram pouca informação, devido ao pequeno número de alelos observados para cada um deles. O compartilhamento desses alelos entre as linhagens fundadoras é outro fator que pode ter influenciado as distâncias estimadas entre eles, reduzindo-as em relação ao mapa consenso; isso particularmente pode ser observado nos quatro últimos marcadores no mapa, que apresentaram de três a quatro alelos, com ao menos um deles sendo compartilhado pelas linhagens parentais, ocasionando muitas meioses de fase desconhecida. O grande número de meioses de fase desconhecida, isto é, a impossibilidade de inferir com certeza a origem parental do alelo, e o intervalo relativamente grande entre os marcadores pode ter sido um dos fatores que dificultou a construção do mapa com todas as famílias em conjunto.

Para construção do mapa de ligação do cromossomo 5 foram utilizados genótipos das mesmas seis famílias F2 completas e da genotipagem seletiva para os marcadores LEI 82, MCW 193, MCW 90, LEI 145, ADL 233 e ADL 298 (592 aves); para o marcador LEI 149 cinco famílias foram genotipadas que, em conjunto com os animais da genotipagem seletiva, totalizaram 494 aves. O mapa foi construído empregando-se todas as famílias em conjunto; o ordenamento obtido foi compatível como apresentado no mapa consenso (Figura 4).

As posições estimadas para os locos variaram pouco em relação ao mapa consenso, com exceção do ADL 233. Esse marcador aparece ligado ao 
LEI 149, marcador que não está posicionado no consenso. O comprimento total obtido para o mapa de ligação do cromossomo 5 foi de 150,6 cM considerando como posição inicial para o primeiro marcador, LEI 82, aquela dada no mapa consenso, de $32 \mathrm{cM}$. Esse comprimento difere um pouco do apresentado no mapa consenso, de $166 \mathrm{cM}$, possivelmente pelas mesmas razões cogitadas para o cromossomo 3 .

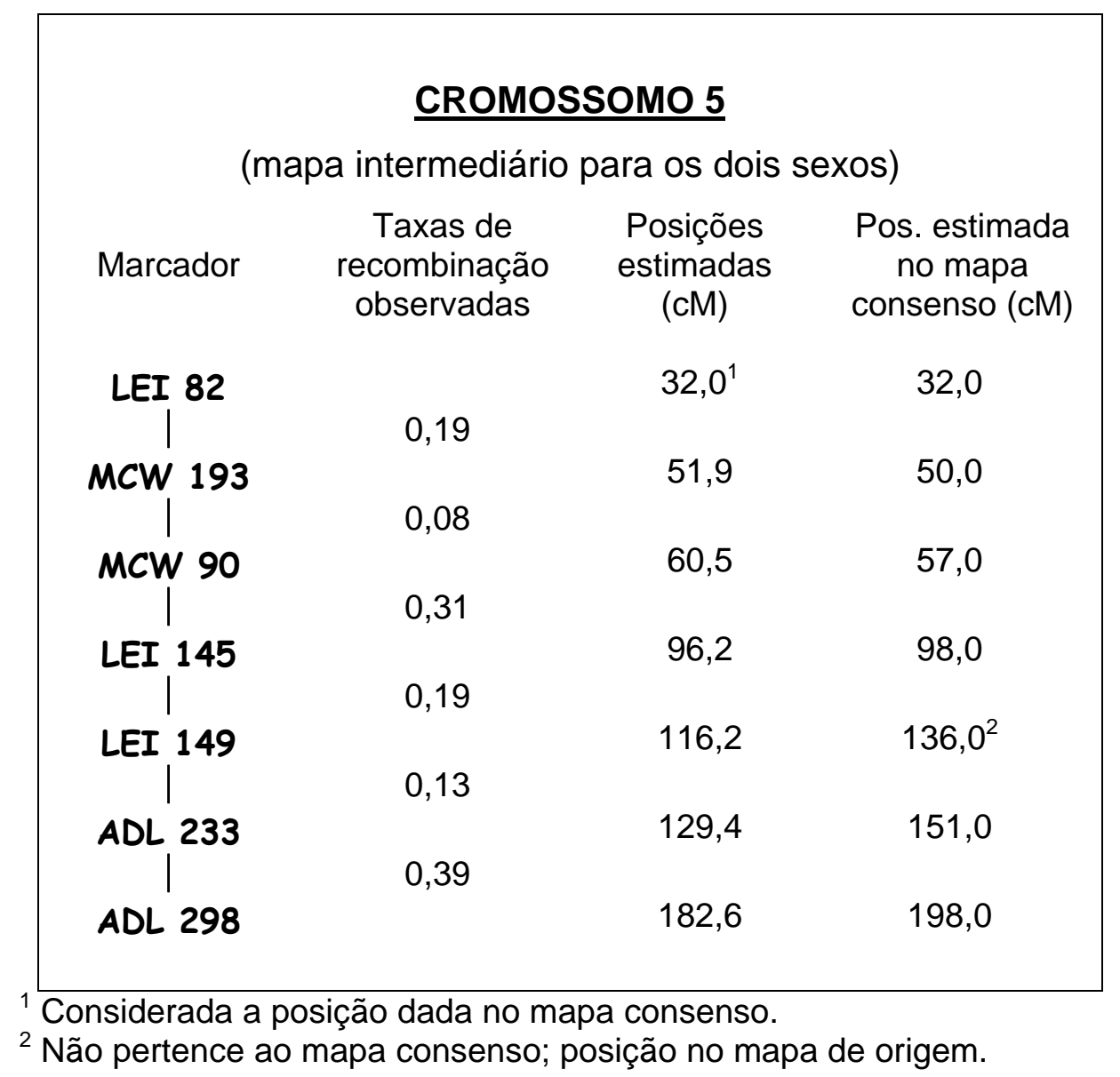

Figura 4 - Mapa de ligação do cromossomo 5, para o cruzamento TC

O intervalo médio obtido entre marcadores foi de $25,1 \mathrm{cM}$, além do desejado, de $20 \mathrm{cM}$. A falta de marcadores informativos disponíveis não permitiu a redução do intervalo médio e permitiu que houvesse uma lacuna de 
53,2 cM entre os marcadores ADL 233 e ADL 298. O marcador ADL 166 está posicionado a $162 \mathrm{cM}$ no mapa consenso, mas não foi informativo para as famílias avaliadas da população em estudo.

A região final do cromossomo 5 tem poucos marcadores mapeados, dificultando a ligação dos últimos locos posicionados. No decorrer do experimento o mapa de ligação para o cromossomo 5 foi inicialmente construído com os genótipos para os marcadores MCW 193, MCW 90, L145, ADL 233 e ADL 298, porém não foi possível ligar esses dois últimos locos. A posição do ADL 298 foi fixada utilizando-se a opção auxiliar fixed no CRI-MAP, utilizando-se sua posição no mapa consenso referente ao ADL 233. Essa mesma dificuldade foi apontada por Yonash et al. (2001), que não conseguiram determinar ligação do marcador ADL 298 com o marcador mais próximo mapeado em seu experimento.

No mapa de ligação definitivo do cromossomo 5 foi obtida a ligação dos marcadores ADL 233 e ADL 298 sem que fosse preciso fixar a taxa de recombinação, quando foi inserido o marcador LEI 149. A distância obtida entre esses dois últimos marcadores variou em 6,2 cM em relação ao mapa consenso.

O número de animais empregados no experimento e de marcadores informativos propiciou uma quantidade de meioses informativas suficiente para gerar confiabilidade nos mapas obtidos. As distâncias empregadas no mapeamento de QTL foram as determinadas para os mapas dos cromossomos 3 e 5 utilizando as aves do cruzamento TC, preferencialmente às distâncias do mapa consenso.

\subsection{Identificação de QTL}

O mapeamento de QTL foi feito empregando-se o programa QTL Express (Seaton et al., 2002) (http://qtl.cap.ed.ac.uk), optando-se pela análise para F2, onde as seis famílias são avaliadas em conjunto. Foram necessários 
para a submissão os mapas de ligação obtidos para os cromossomos 3 e 5 , além de duas planilhas, uma contendo os genótipos dos indivíduos pertencentes às seis famílias F2 para os marcadores posicionados no mapa, sob a forma de estrutura familiar, e outra contendo os fenótipos ajustados para vinte e oito características medidas ou calculadas, referentes aos mesmos indivíduos da planilha de genótipos.

Análises prévias utilizando o programa SAS indicaram efeitos significativos de sexo, família e incubação, bem como interações entre eles, para os valores fenotípicos encontrados. Todo efeito significativo deveria ser adicionado ao modelo empregado para a análise de QTL. No entanto, não é possível a adição das interações no modelo de regressão utilizado pelo QTL Express, pela impossibilidade de construir uma matriz adequada à interpretação dos dados. Além disso, o efeito de incubação mistura efeito da estação do ano e possíveis interações genéticas bem como o efeito da idade da mãe à época da postura. A dificuldade em interpretar possíveis interações de um QTL com esse efeito, bem como evitar as interações entre sexo $X$ incubação, família $X$ incubação e sexo $X$ família foram fatores determinantes na opção de ajuste dos dados e obtenção dos resíduos, os quais mantiveram ainda os efeitos de sexo e família, sendo estes então adicionados como efeitos fixos ao modelo linear.

As vinte e oito características tiveram seus resíduos considerados como variáveis dependentes nos modelos de regressão linear testados no QTL Express. O modelo inicial testado foi para a presença de um QTL, considerando como efeitos fixos família e sexo. As covariáveis empregadas foram PV35 para GP35-41, CA35-41 e EF35-41, e PV42 para pesos de CARC, CAB, PES, FIG, PULM, MOEL, COR, ASA, COXA, PEIT, COST, CINT, GORD e HEMAT. As características restantes não tiveram covariáveis adicionadas ao modelo, pois não houve covariável significativa na análise prévia conduzida no SAS.

Foram identificados QTL para PV42, PV41, PV35, ASA, PES, COXA, GORD e PGORD no cromossomo 3 e para CR, COR, GORD e PGORD no 
cromossomo 5, quando considerados os níveis de significância no cromossomo, obtidos na opção chromosome-wise do QTL Express (Tabela 15).

As posições para os QTL apresentadas na tabela são dadas a partir do início do cromossomo e não a partir do primeiro marcador mapeado, como apresentado em alguns trabalhos, para que a comparação com o posicionamento de QTL observados em outros estudos de mapeamento seja simplificada. Os valores de $F$ encontrados para GP35-41, CA, EF, CARC, COST, CAB, MOEL, FIG, PULM, PCARC, PPEIT e HEMAT não foram significativos em nenhum dos cromossomos, não indicando portanto a presença de QTL para essas características.

Os valores de $F$ obtidos para GORD e PGORD no cromossomo 5 ficaram no limiar de significância na primeira análise feita no QTL Express; como foi encontrado QTL significativo para essas características no cromossomo 3, um possível efeito de background foi considerado. Quando os QTL observados no cromossomo 3 foram incluídos como cofatores no modelo e as análises foram refeitas para essas características, os QTL para GORD e PGORD no cromossomo 5 passaram a ser significativos.

McElroy et al. (2002) relataram a presença de QTL no cromossomo 3 para peso vivo às seis semanas de idade, pré-transporte, a $154 \mathrm{cM}$, distando 34 cm do QTL encontrado no presente estudo; os autores porém utilizaram a posição dos marcadores dada no mapa consenso, que difere de algumas posições encontradas para a população aqui empregada; além disso os autores não apresentaram intervalo de confiança, o que impede qualquer inferência relacionando os QTL identificados nos dois experimentos.

Sewalem et al. (2002), trabalhando também com população originada de linhagens de corte e de postura visando mapear QTL para peso corporal a três, seis e nove semanas de idade, utilizaram um número de marcadores e uma cobertura do cromossomo 3 muito próxima a deste experimento, porém não encontraram QTL nesse cromossomo para essas características. 
Tabela 15. QTL mapeados nos cromossomos 3 e 5 de aves para características de desempenho e de carcaça, intervalos de confiança e valores de $\mathrm{F}$ no cromossomo

\begin{tabular}{llclc}
\hline QTL $^{1}$ & Posição & Marcadores do & Intervalo de & $\mathrm{F}$ \\
& em cM & Intervalo & $\begin{array}{l}\text { Confiança } \\
95 \%(\mathrm{cM})\end{array}$ & Observado \\
& & \\
\hline
\end{tabular}

\section{Cromossomo 3}

\section{Características de Desempenho}

$\begin{array}{lllll}\text { PV42 } & 120 & \text { LEI161 - LEI29 } & 14 \text { a } 215 & 13,05 \text { ** } \\ \text { PV35 } & 120 & \text { LEI161 - LEI29 } & 61 \text { a } 129 & 16,10^{\text {** }} \\ \text { PV41 } & 120 & \text { LEI161 - LEI29 } & 20 \text { a } 219 & 13,56 \text { ** } \\ \text { GPN-35 } & 120 & \text { LEI161 - LEI29 } & 61 \text { a } 128,5 & 16,12^{\text {** }} \\ \text { GPN-41 } & 120 & \text { LEI161 - LEI29 } & 20 \text { a 216 } & 13,58 \text { ** } \\ \text { GPN-42 } & 120 & \text { LEI161 - LEI29 } & 14 \text { a } 217,5 & 13,07 \text { ** }\end{array}$

Cromossomo5

$\begin{array}{lllll}\text { CR } & 198 & \text { ADL298 } & 32 \text { a } 198 & 6,98^{\star *}\end{array}$

\section{Cromossomo 3}

\section{Características de Carcaça}

\begin{tabular}{|c|c|c|c|c|}
\hline COXA & 158 & ADL371 - LEI118 & 106 a 268 & 7,65 ** \\
\hline ASA & 163 & ADL371 - LEI118 & 111 a 255,5 & 9,36 ** \\
\hline PES & 122 & LEI29 - ADL371 & 49 a 281 & 6,62 * \\
\hline GORD & $121(123)^{3}$ & LEI29 - ADL371 & 68 a 211 & $7,95(8,54)$ \\
\hline PGORD & $121(121)^{3}$ & LEI29 - ADL371 & 102 a 130 & $13,59(1$ \\
\hline \multicolumn{5}{|c|}{$\underline{\text { Cromossomo } 5}$} \\
\hline$D R$ & 69 & MCW90 - LEI145 & 35 a 151 & \\
\hline PRD & 187 & ADL233 - ADL298 & 50 a 198 & \\
\hline$R D$ & 185 & ADL233 - ADL298 & 51 a 198 & \\
\hline
\end{tabular}

\footnotetext{
${ }^{1}$ PV42=peso vivo aos 42 dias, pós-transporte; PV35=peso vivo aos 35 dias; PV41=peso vivo aos 41 dias; GPN35=ganho de peso do nasc. aos 35 dias; GPN41=ganho de peso do nasc. aos 41 dias; GPN42=ganho de peso do nasc. aos 42 dias; $C R=$ consumo de ração do $35^{\circ}$ ao $41^{0}$ dia; PES= peso dos pés (g); COR=peso do coração (g); ASA=peso do par de asas (g); COXA=peso do par de coxas e sobrecoxas (g); GORD=peso da gordura abdominal (g); PGORD= porcentagem de gordura.

${ }^{2}$ Posições dadas a partir do início do cromossomo $(0 \mathrm{cM})$.

${ }^{3}$ Valores entre parênteses indicam as posições $e$ valores do $F_{\text {obs }}$ considerando efeito de imprinting.

** Significativo a $1 \%$ no cromossomo. * Significativo a 5\% no cromossomo.
} 
Van Kaam et al. (1999b) apontaram o intervalo entre os marcadores LEI 166 e MCW 116 como região potencial para ocorrência de QTL para peso aos 48 dias de idade e para peso de carcaça. No presente trabalho os testes independentes de qui-quadrado aplicados na genotipagem seletiva indicaram ligação do marcador MCW 116 com a característica PV42, porém esse marcador foi informativo para apenas uma das famílias selecionadas, e não foi genotipado posteriormente. O marcador mais próximo, LEI 166, foi genotipado, contudo os resultados finais não sugeriram QTL para nenhuma característica nessa região final do cromossomo 3.

Deve contudo ser lembrado que alguns marcadores selecionados pelo teste de qui-quadrado poderiam ser descartados, pois os valores de significância obtidos nesse teste foram considerados individualmente, sem qualquer preocupação quanto a um nível bem menor de significância a ser considerado, já que vários testes foram feitos e que falsos positivos pudessem estar ocorrendo.

O único QTL relacionado a desempenho mapeado no cromossomo 5 está relacionado ao consumo de ração, localizado a 198 cM; o intervalo contudo de confiança a $95 \%$ tem a amplitude de todo o cromossomo. A posição onde foi observado o maior valor de $\mathrm{F}$ obtido em 10000 permutações corresponde à posição ocupada pelo marcador ADL 298, relacionado anteriormente com resposta imune e resistência resistência a E. coli por Yonash et al. (2001).

Foram mapeados QTL para ASA e COXA no cromossomo 3, a 158 e 163 cM; considerando que são bastante próximos e que os intervalos de confiança se sobrepõem, possivelmente trata-se de um mesmo QTL. McElroy et al. (2002) encontraram QTL em frangos para pesos de meia carcaça dianteira, de filé e de carne branca a $154 \mathrm{cM}$, região muito próxima a do QTL encontrado neste estudo. Entretanto, assim com no estudo de McElroy el al. (2002), nesta pesquisa também foi investigada a presença de QTL para peso de peito e peso de carcaça, porém não foram encontrados QTL para essas características. 
Foi identificado um QTL para PES no cromossomo 3, com significância de $5 \%$ no cromossomo, a 122 cM. Essa posição é próxima da encontrada para o QTL influenciando pesos e ganhos a diferentes idades, podendo tratar-se do mesmo QTL influenciando todas essas características.

Foram observados QTL significativos para as características GORD e PGORD no cromossomo 3, ambos a 121 cM. Ao ser testada a ocorrência de imprinting sobre GORD e PGORD, os modelos incluindo esse efeito apresentaram melhoria significativa em relação ao modelos sem imprinting, com valores para os testes $\mathrm{F}$ comparando os modelos com e sem imprinting de 8,43 para GORD e 9,95 para PGORD (valores não mostrados em tabela) para GORD e PGORD respectivamente, no cromossomo 3. A posição do QTL para GORD considerando imprinting apresentou um desvio de $2 \mathrm{cM}$, não significando necessariamente que 2 QTL diferentes atuem sobre GORD e PGORD; possivelmente trata-se do mesmo QTL.

Ikeobi et al. (2002) mapearam um QTL no cromossomo 3 a $40 \mathrm{cM}$ ( $\mathrm{P}<0,05$ no genoma) associado com peso de gordura abdominal, porém o intervalo de confiança obtido se sobrepõe ao intervalo aqui encontrado para o QTL associado a GORD nesses cromossomo. McElroy el al. (2002) também investigaram QTL para características associadas com gordura em seus estudos de mapeamento, mas não encontraram QTL no cromossomo 3.

O QTL identificado para GORD e PGORD no cromossomo 3 provavelmente é o mesmo QTL para PV35, PV41, PV42, GPN35, GPN41, GPN42 e possivelmente para PES observado no mesmo cromossomo. McElroy el al. (2002) relacionam a ocorrência de vários QTL para diferentes características na mesma posição com QTL com efeito pleiotrópico. O posicionamento comum para vários QTL mapeados neste estudo parece também condizente com efeito de pleiotropia.

Foram encontrados QTL para GORD e PGORD também no cromossomo 5 , após terem sido isolados os efeitos dos QTL no cromossomo 3, ao serem adicionados como cofatores nos modelos. Contudo, não foi o suficiente para 
elevar os níveis de significância desses QTL a mais de 5\% no cromossomo. Os QTL foram posicionados a 187 e 185 cM para GORD e PGORD, respectivamente, se tratando possivelmente do mesmo grupo de genes atuando nas duas características.

McElroy et al. (2002) empregando análise de marca simples, associaram um QTL para peso de gordura com o marcador MCW 193, posicionado a $50 \mathrm{cM}$ segundo o mapa consenso. Ikeobi et al. (2002) mapearam um QTL no cromossomo 5, a $82 \mathrm{cM}$, significativamente associado ( $P<0,01$ no genoma) com peso de gordura abdominal, com pequeno intervalo de confiança. Em ambos os casos não foi possível relacionar os QTL encontrados com o QTL sugestivo para GORD aqui encontrado.

O fenômeno de imprinting observado para GORD e PGORD no cromossomo 3 é raro em trabalhos de mapeamento de QTL em aves. Moore \& Haig (1991) mencionaram que o imprinting gamético não aconteceria em aves; essa afirmação não é conclusiva, pois os autores consideraram que o efeito da origem parental do alelo se relacione quase exclusivamente com desenvolvimento placentário e que ovíparos não sofrem esse processo.

Buitenhuis et al. (2003) relataram efeito de imprinting para caracteristica distinta daquelas avaliadas neste trabalho, e advertiram que há muita discordância em relação à ocorrência de imprinting em aves. Siwek et al. (2003) também observaram efeito da origem parental do alelo em QTL sugestivos mapeados em seu trabalho avaliando resposta imunológica de galinhas poedeiras, e sugeriram que as evidências biológicas atuais para efeito de imprinting em aves poderiam ser comprovadas a partir de estudos de expressão ao nível do RNA e da proteína.

Segundo de Koning et al., (2002), simulando efeitos de imprinting genômico em populações de suínos, a ocorrência de imprinting deve ser cuidadosamente avaliada, pois um número pequeno de pais F1 pode induzir a um falso resultado. Contudo, os mesmos autores afirmam que encontrar um falso efeito de imprinting é menos grave que encontrar um falso QTL, e que um 
resultado indicando efeito de imprinting merece ser relatado, feitas essas ressalvas.

Além de se testar efeito de imprinting para as características onde foram identificados QTL significativos, também foram testadas as interações do QTL com sexo e família, porém não foram significativas. A ausência de interações significativas dos QTL com o sexo das aves indicou que a análise conjunta dos dois sexos foi correta. A ausência de interações significativas dos QTL com família indicou que não houve diferentes QTL segregando dentro de famílias, e a análise das famílias em conjunto na opção F2, ao invés da opção half-sib, foi adequada para o conjunto de dados disponíveis.

Os intervalos de confiança para todos os QTL encontrados foram obtidos empregando-se a técnica de bootstrap proposta por Visscher et al. (1996), variando de $28 \mathrm{cM}$ para QTL relacionado a PGORD no cromossomo 3, a 201 cM para QTL relacionado a PV42 também no cromossomo 3. Os intervalos são bastante amplos, contudo podem ser comparados aos obtidos por Ikeobi et al. (2002), que variaram de 21 a 237 cM, e os obtidos por Sewalem et al. (2002), que variaram de 35 a $100 \mathrm{cM}$.

Os valores de F observados para os QTL mapeados foram significativos com uma probabilidade de aos menos $5 \%$ nos cromossomos, equivalendo ao primeiro nível de significância que poderia ser considerado, segundo Lander \& Kruglyak (1995). O segundo nível de significância para se considerar uma ligação sugestiva, ou seja, a chance de não se encontrar mais do que um falso positivo na varredura de todo o genoma seria obtido fazendo-se a relação entre o comprimento de cada cromossomo em relação ao comprimento do genoma autossômico.

Este experimento visou o mapeamento de QTL nos cromossomos 3 e 5, com cobertura estimada de 313 e 190,6 cM, respectivamente, considerando uma cobertura adicional de $20 \mathrm{cM}$ em cada extremidade dos cromossomos; a extensão do genoma considerada foi de 3800 cM (Groenen et al. 2000). Os valores de probabilidade calculados foram 0,082 e 0,050, acima dos quais a 
ligação marcador-QTL pode ser considerada sugestiva nos cromossomos 3 e 5, respectivamente.

Embora a busca exploratória por QTL ter se limitado apenas aos cromossomos 3 e 5, foram determinados os níveis de significância com probabilidades de 5 e 1\% no genoma (genome-wise), através da aplicação da correção de Bonferroni. Lander \& Kruglyak (1995) recomendam que sempre se considerem níveis de significância para o genoma, justificando que, se um resultado positivo não for encontrado, o pesquisador acabará estendendo a busca por mais cromossomos e aumentando assim o número de testes. Contudo não é o caso deste experimento, cuja dimensão foi previamente definida. Outra justificativa é apontada por de Koning et al. (1999) e Walling et al. (2000), afirmando que a determinação dos níveis de significância para o genoma auxilia a comparação dos valores de $\mathrm{F}$ e, conseqüentemente, dos níveis de significância publicados em outros trabalhos, inclusive naqueles em que todo o genoma foi investigado.

Todos os valores de $\mathrm{F}$ equivalentes às probabilidades foram obtidos a partir de 10000 permutações, segundo recomendação de Churchill \& Doerge (1995). Os valores de F para os QTL encontrados e seus respectivos níveis de significância nos níveis do experimento e do genoma estão relacionados na Tabela 16.

Os valores limites de F para ligação sugestiva e níveis de significância de 5 e $1 \%$ no no genoma foram calculados individualmente para cada característica a partir das 10000 permutações efetuadas. Considerando-se os valores de $F$ para todo o genoma, os QTL observados para GORD nos cromossomos 3 e 5 e para PGORD no cromossomo 5 foram considerados apenas sugestivos. Os QTL mapeados para COXA e PES no cromossomo 3 e para CR e COR no cromossomo 5 foram também considerados sugestivos. Para as características de peso corporal, de ganho de peso e relacionadas à gordura, os QTL foram significantes a $1 \%$ no genoma, enquanto para peso de asas a significância do QTL foi de 5\%. 
Tabela 16. Valores de $F$ significativos no cromossomo e no genoma, determinados para os QTL mapeados nos cromossomos 3 e 5 de aves TC

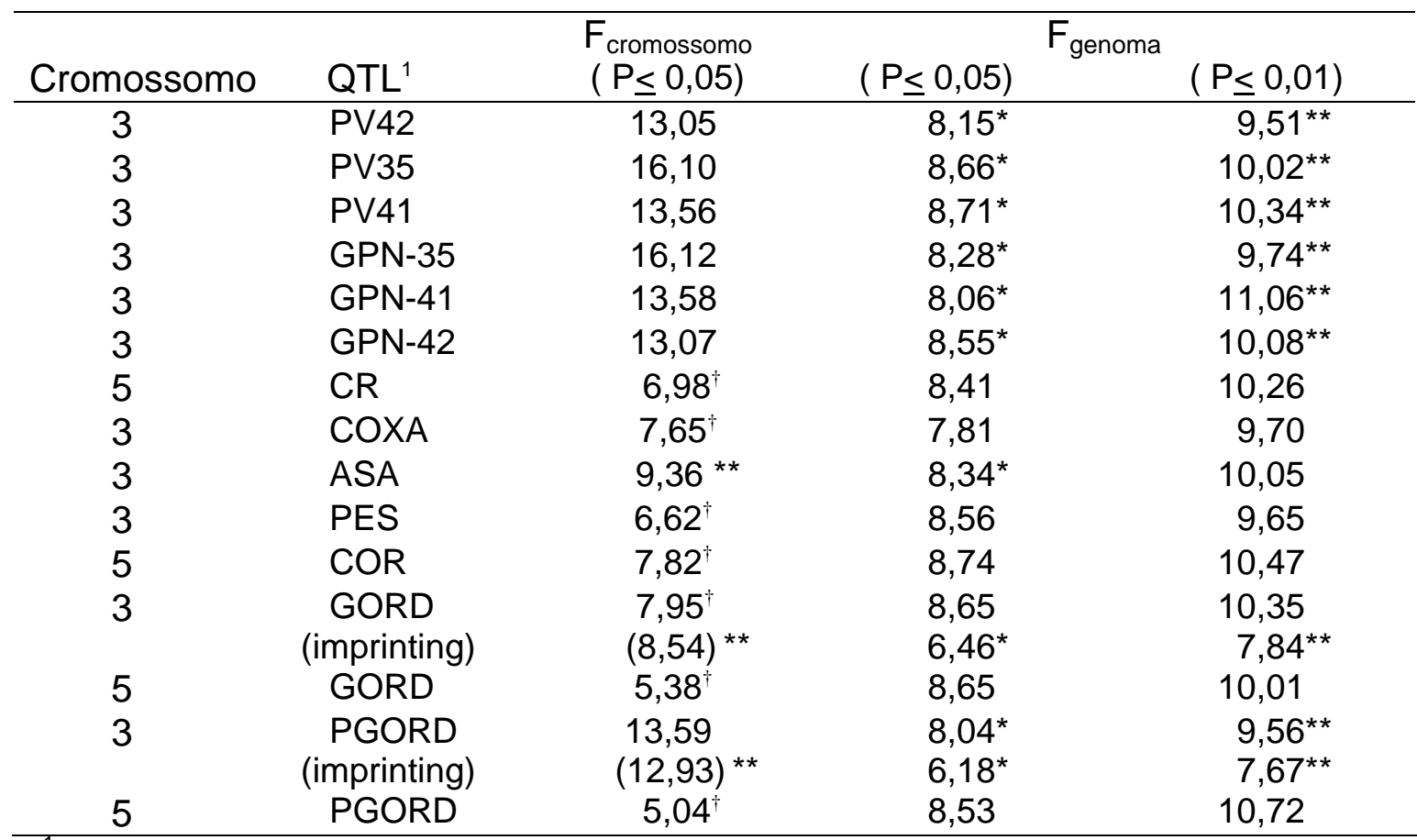

${ }^{1}$ PV42=peso vivo aos 42 dias, pós-transporte; PV35=peso vivo aos 35 dias; PV41=peso vivo aos 41 dias; GPN35=ganho de peso do nasc. aos 35 dias; GPN41=ganho de peso do nasc. aos 41 dias; GPN42=ganho de peso do nasc. aos 42 dias; $C R=$ consumo de ração do $35^{\circ}$ ao $41^{0}$ dia; PES= peso dos pés (g); COR=peso do coração (g); ASA=peso do par de asas (g); COXA=peso do par de coxas e sobrecoxas (g); GORD=peso da gordura abdominal (g); PGORD= porcentagem de gordura.

${ }^{\dagger}$ ligação sugestiva. * QTL significativo no genoma a 5\%. ** QTL significativo no genoma a 1\%

Para apresentação gráfica dos QTL mapeados e seus níveis de significância, foram agrupadas as características com QTL mapeados em um mesmo cromossomo, e considerados valores de $\mathrm{F}$ médios para cada nível de significância. São apresentados QTL influenciando: peso corporal em diferentes idades no cromossomo 3, ganhos de peso em diferentes idades no cromossomo 3, partes da carcaça no cromossomo 3, relacionadas à gordura no cromossomo 3, peso de coração e consumo de ração no cromossomo 5 e relacionadas à gordura no cromossomo 5 (Figuras 5 a10). As médias obtidas divergiram pouco dos valores limites de F para as características. 


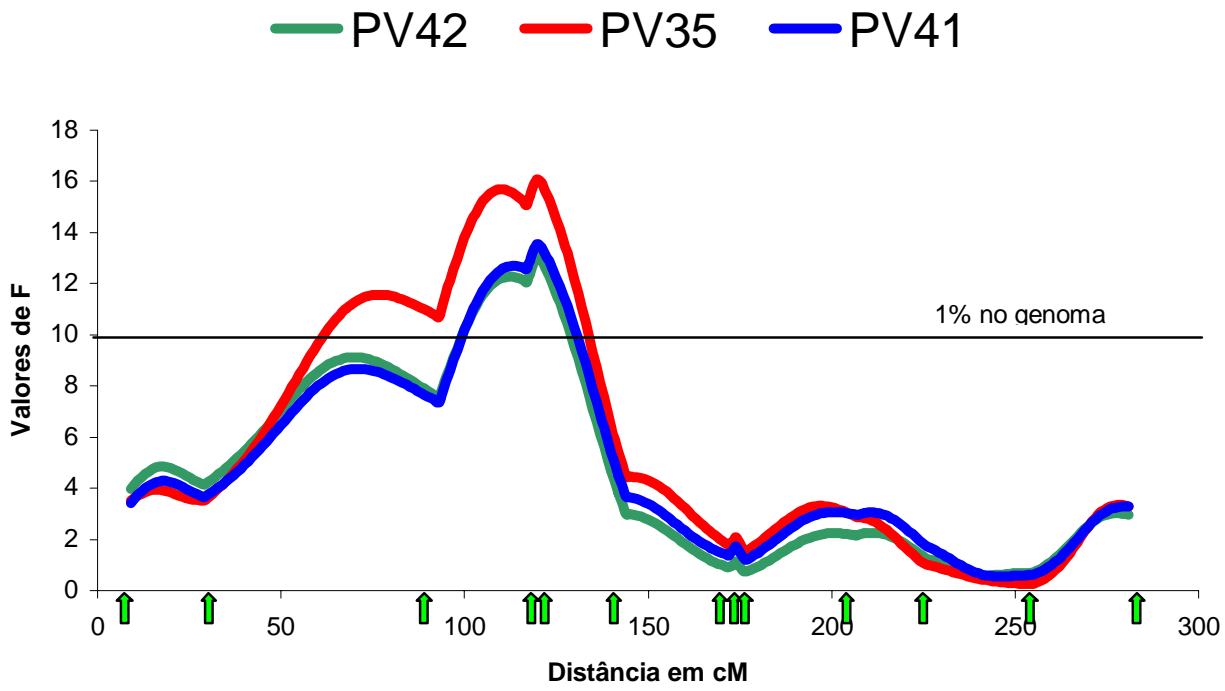

Figura 5 - QTL mapeados no cromossomo 3 influenciando o peso vivo aos 35 (PV35, em vermelhol), 41 (PV41, em azul) e 42 dias (PV42, em verde); a linha cortando os gráficos representa o valor limite de $F$ para significância a $1 \%$ no genoma. Setas em verde indicam as posições dos marcadores posicionados no cromossomo
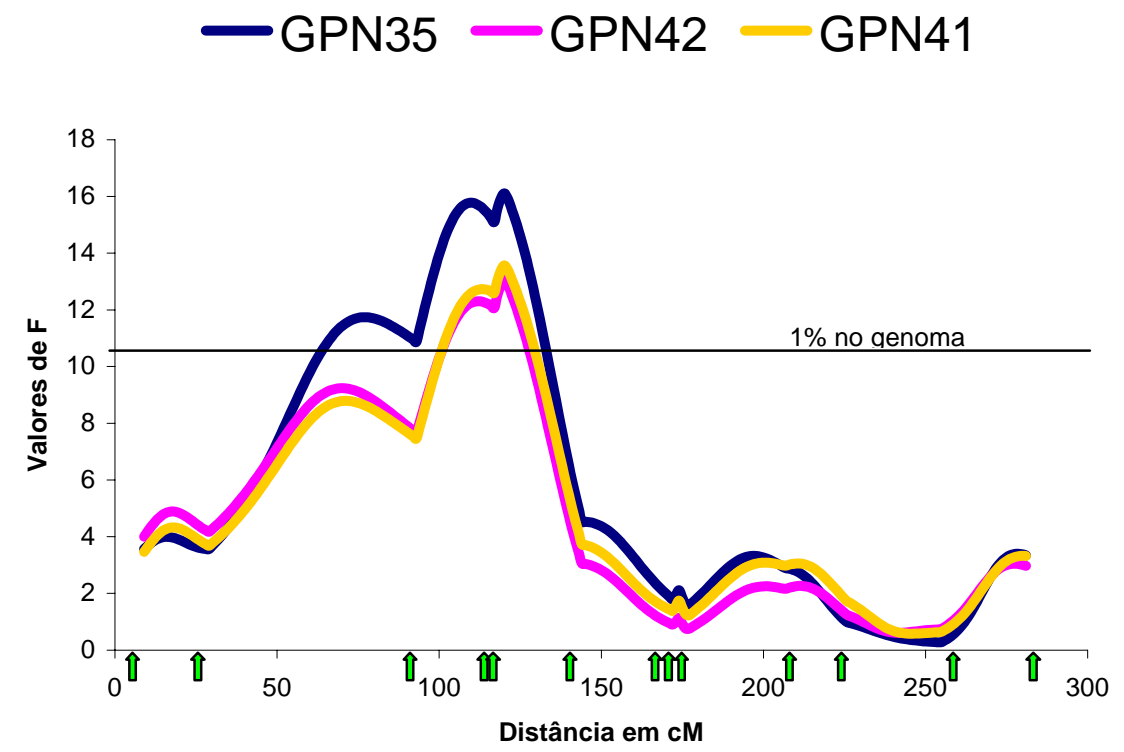

Figura 6 - QTL mapeadosnocromossomo 3 influenciando o ganho de peso donascimento aos 35 (GPN35, em azul), 41 (GPN41, em amarelo) e 42 dias (GPN42), em rosa); a linha cortando osgráficos representa $o$ valor limite de $F$ para significância a1\% no genoma. Assetas em verdeindicam asposições dos marcadores posicionados nocromossomo 


\section{- PES - ASA - COXA}

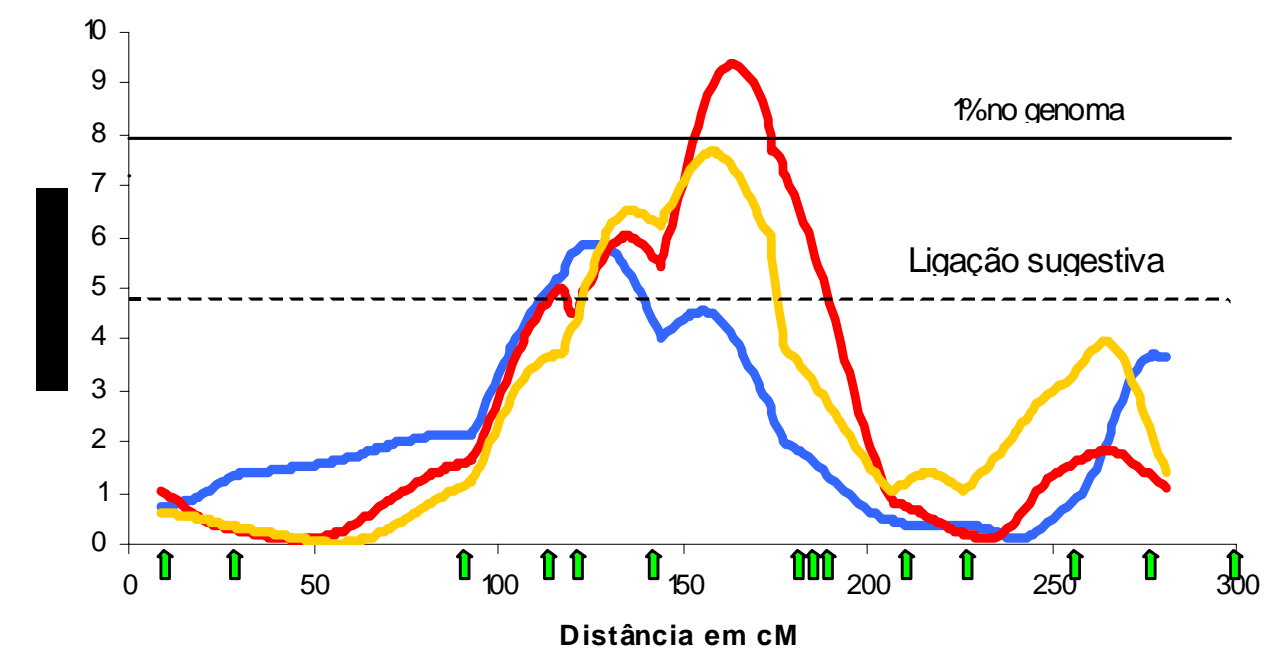

Figura 7 - QTL mapeados no cromossomo 3 influenciando o pesode pés (PES, em azul), asas (ASA, em vermelho) ecoxase sobrecoxas (COXA, em amarelo); a linhacortando os gráficos representa os valores limitesde $F$ parasignificância a $1 \%$ no genoma $e$ ligação sugestiva. Assetas em verde indicam as posições dos marcadores posicionados no cromossomo
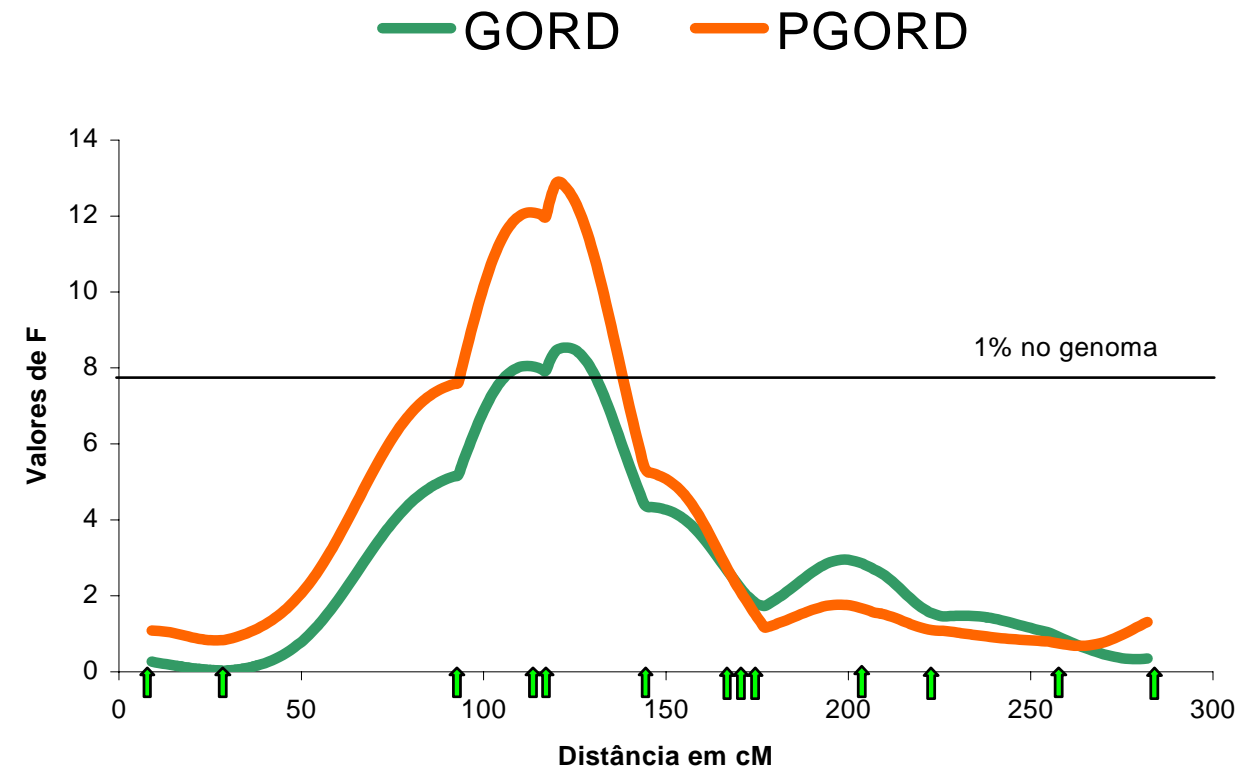

Figura 8 - QTL mapeados no cromossomo 3 influenciando o peso da gordura abdominal (GORD, em verde) e da porcentagem de gordura abdominal (PGORD, em laranja); a linha cortando os gráficos representa o valor limite de $F$ para significância a 1\% no genoma. As setas em verde indicam as posições dos marcadores posicionados no cromossomo 


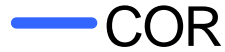

$\longrightarrow \mathrm{CR}$

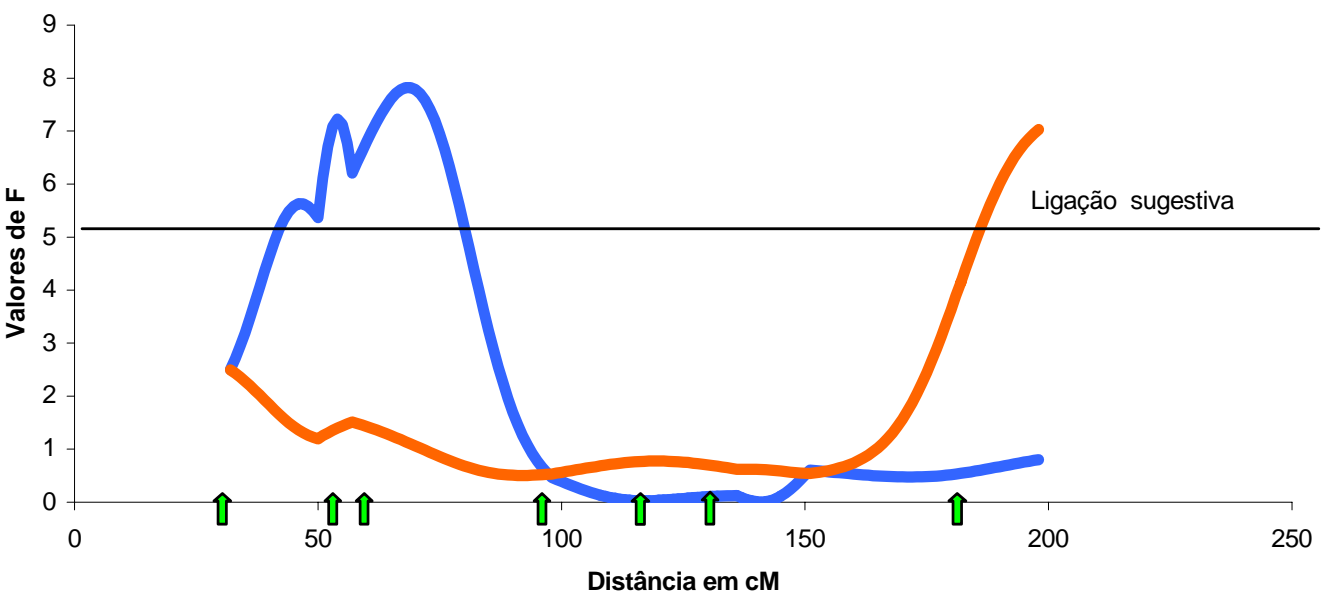

Figura 9 - QTL mapeados no cromossomo 3 influenciando o peso pés (PES em azul), de asas (ASA em vermelho) e de coxas (COXA em amarelo); as linhas cortando os gráficos representam o valor limite de $\mathrm{F}$ para o nível de significância para ligação sugestiva. As setas em verde indicam as posições dos marcadores posicionados no cromossomo
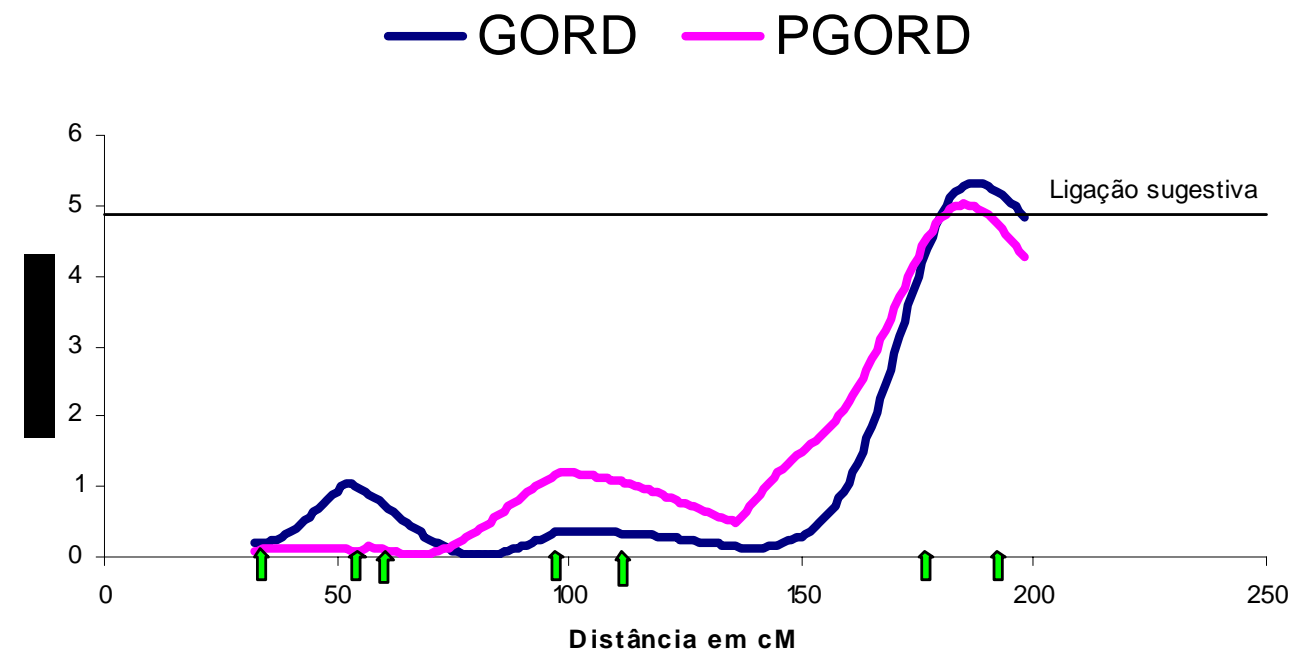

Figura 10 - QTL mapeados no cromossomo 5 influenciando o peso da gordura abdominal (GORD, em azul) e da porcentagem de gordura abdominal (PGORD, em rosa); a linha cortando os gráficos representa o valor limite de F para o nível de significância para ligação sugestiva. As setas em verde indicam as posições dos marcadores posicionados no cromossomo 
Os efeitos aditivos e de dominância e a porcentagem da variância fenotípica explicada por cada QTL encontrado são apresentados na Tabela 17.

Tabela 17. Efeitos aditivos e de dominãncia dos QTL para características de desempenho e de carcaça

\begin{tabular}{clrrr}
\hline Cromossomo & QTL $^{1}$ & $\begin{array}{c}\text { Aditivo } \\
\text { (erro-padrão) }\end{array}$ & $\begin{array}{r}\text { Dominância } \\
\text { (erro-padrão) }\end{array}$ & $\begin{array}{c}\text { \% variância } \\
\text { fenotípica }\end{array}$ \\
\hline 3 & PV35 & $37,23(6,75)$ & $-15,76(9,72)$ & 5,46 \\
3 & PV41 & $44,98(8,77)$ & $-14,48(12,62)$ & 4,58 \\
3 & PV42 & $43,63(28,63)$ & $-12,16(12,42)$ & 4,41 \\
3 & GPN-35 & $37,25(6,75)$ & $-15,56(9,71)$ & 5,47 \\
3 & GPN-41 & $45,00(8,76)$ & $-14,28(12,61)$ & 4,59 \\
3 & GPN-42 & $43,65(8,62)$ & $-11,96(12,41)$ & 4,41 \\
5 & CR & $15,45(5,79)$ & $-21,56(9,54)$ & 2,24 \\
3 & ASA & $-1,09(0,25)$ & $-0,35(0,42)$ & 3,10 \\
3 & COXA & $-2,85(0,73)$ & $-0,35(1,28)$ & 2,48 \\
3 & PES & $-0,69(0,20)$ & $-0,16(0,28)$ & 2,11 \\
5 & COR & $-0,01(0,08)$ & $0,52(0,13)$ & 2,51 \\
3 & GORD & $1,15(0,30)$ & $-0,60(0,43)$ & 2,59 \\
& (imprinting) & $1,22(0,31)$ & $-0,69(0,46)$ & 4,15 \\
5 & GORD & $1,01(0,40)$ & $-1,43(0,80)$ & 1,66 \\
3 & PGORD & $0,16(0,03)$ & $-0,07(0,05)$ & 4,58 \\
& (imprinting) & $0,16(0,03)$ & $-0,08(0,05)$ & 6,37 \\
5 & PGORD & $0,12(0,04)$ & $-0,11(0,09)$ & 1,53 \\
\hline
\end{tabular}

${ }^{1}$ PV42=peso vivo aos 42 dias, pós-transporte; PV35=peso vivo aos 35 dias; PV41=peso vivo aos 41 dias; GPN35=ganho de peso do nasc. aos 35 dias; GPN41=ganho de peso do nasc. aos 41 dias; GPN42=ganho de peso do nasc. aos 42 dias; $C R=$ consumo de ração do $35^{\circ}$ ao $41^{0}$ dia; PES= peso dos pés (g); COR=peso do coração (g); ASA=peso do par de asas (g); COXA=peso do par de coxas e sobrecoxas (g); GORD=peso da gordura abdominal (g); PGORD= porcentagem de gordura.

${ }^{2}$ Os valores foram obtidos a partir dos resíduos e são dados em gramas, com exceção de CR e PGORD.

${ }^{3}$ Os efeitos do imprinting e seus erros-padrão foram de $0,95(0,31)$ e $0,10(0,03)$ para GORD e PGORD respectivamente, no cromossomo 3.

Os QTL relacionados a PV35, PV41, PV42, GPN35, GPN41, GPN42, GORD e PGORD no cromossomo 3 e CR no cromossomo 5 apresentaram efeitos aditivos positivos, indicando que os alelos aumentando os valores das 
características foram provenientes da linhagem parental TT. A semelhança observada nos efeitos sustenta a hipótese de que o mesmo QTL esteja atuando em todas essas características.

Os efeitos aditivos negativos para os QTL relacionados às características ASA, COXA e PES indicaram que os alelos provenientes da linhagem CC parental influenciam essas características, diminuindo seus pesos.

Houve efeito de dominância para os QTL relacionados a CR, COR, GORD e possivelmente para PGORD no cromossomo 5. Os efeitos de dominância negativos observados indicaram que os indivíduos que receberam um alelo da linhagem de corte TT e o outro alelo da linhagem de postura CC tiveram uma menor média para essas características do que a média dos homozigotos. 


\section{CONCLUSÕES}

1. A população experimental da EMBRAPA é adequada para estudos de mapeamento de QTL do ponto de vista dos marcadores, pois estes apresentaram valores de heterozigosidade e PIC para as aves do cruzamento TC superiores aos previamente publicados para linhagens comerciais de frangos.

2. Os mapas de ligação construídos para os cromossomos 3 e 5 a partir da população TC foram adequados para serem utilizados na análise de mapeamento de QTL na população TC, pois ao serem utilizados na análise de QTL permitiram a detecção de vários QTL significativos.

3. Foi mapeado um QTL significativo para PV35, PV41, PV42, GPN35, GPN41e GPN42, e sugestivo para PES, com posição variando entre 120 e $123 \mathrm{cM}$, no cromossomo 3.

4. Foi mapeado um QTL significativo para GORD e PGORD variando entre 121 e $123 \mathrm{cM}$, ambos com efeito significativo de imprinting, no cromossomo 3.

5. Foi mapeado um QTL significativo para ASA e sugestivo para COXA, variando entre 158 e $163 \mathrm{cM}$, respectivamente, no cromossomo 3.

6. Foram mapeados três QTL sugestivos para COR, CR, e GORD e PGORD a 69, 198, 187 e 185 cM, respectivamente, no cromossomo 5. 


\section{REFERÊNCIAS BIBLIOGRÁFICAS}

ANDERSSON, L.; HALEY, C.S.; ELLEGREN, H.; KNOTT, S.A. JOHANSSON, M.; ANDERSSON, K.; ANDERSSON-EKLUND, L.; EDFORS-LILJA, I.; FREDHOLM, M.; HANSSON, I.; HAKANSSON, J.; LUNDSTRÖM, K. Genetic mapping of quantitative trait loci for growth and fatness in pigs. Science, v.263, p.1771-1774, Mar. 1994.

BARON, E.E; RUY, D.C.; NONES, K.; LEDUR, M.C.; ZANELLA, E.L.; COUTINHO, L.L. Avaliação de marcadores microssatélites para mapeamento de QTL nos cromossomos 1, 2, 3, 4 e 5 de aves. In: REUNIÃO DA SOCIEDADE BRASILEIRA DE GENÉTICA, 47., Águas de Lindóia, 2001. Resumos. Águas de Lindóia: SBG, 2001.

BECKMANN, J.S.; SOLLER, M. Detection of linkage between marker loci and loci affecting quantitative traits in crosses between segregating populations. Theoretical and Applied Genetics, v.76, p.228-236, 1988.

BOVENHUIS, H.; SPELMAN, R.J. Selective genotyping to detect quantitative trait loci for multiple traits in outbred populations. Journal of Dairy Science, v.83, p.173-180, 2000. 
BOVENHUIS, H.; VAN AENDONK, J.A.M.; DAVIS, G.; ELSEN, J.M.; HALEY, C.S.; HILL, W.G.; BARET, P.V.; HETZEL, D.J.S.; NICHOLAS, F.W. Detection and mapping of quantitative trait loci in farm animals. Livestock Production Science, v.52, p.135-144, 1997.

BUITENHUIS, A.J.; RODENBURG, T.B.; VAN HIERDEN, Y.M.; SIWEK, M.; CORNELISSEN, S.J.B.; NIEUWLAND, M.G.B.; CROOIJMANS, R.P.M.A.; GROENEN, M.A.M.; KOENE, P.; KORTE, S.M.; BOVENHUIS, H.; VAN DER POEL, J.J. Mapping quantitative trait loci affecting feather pecking behavior and stress response in laying hens. Poultry Science, v.82, p.1215-1222, 2003.

BUITENHUIS, A.J.; RODENBURG, T.B.; SIWEK, M.; CORNELISSEN, S.J.B.; NIEUWLAND, M.G.B.; CROOIJMANS, R.P.M.A.; GROENEN, M.A.M.; KOENE, P.; BOVENHUIS, H.; VAN DER POEL, J.J. Identification of quantitative trait loci for receiving pecks in young and adult laying hens. Poultry Science, v.82, p.1661-1667, 2003.

BUMSTEAD, N.; PALYGA, J. A preliminary linkage map of the chicken genome. Genomics, v.13, p.690-697, 1992.

CHENG, H.H. Mapping the chicken genome. Poultry Science, v.76, p.11011107, 1997.

CHENG, H.H.; CRITTENDEN, L.B. Microsatellite markers for genetic mapping in the chicken. Poultry Science, v.73, p.539-546, 1994. 
CHENG, H.H.; LEVIN, I.; VALLEJO, R.L.; KHATIB, H.; DODGSON, J.B.; CRITTENDEN, L.B.; HILLEL, J. Development of a genetic map of the chicken with markers of high utility. Poultry Science, v.74, p.1855-1874, 1995.

COELHO, S.G.; SILVA, H.D. Construção de mapas genéticos e mapeamento de QTL. Piracicaba: ESALQ/USP, 2002. 66p.

CRITTENDEN, L.B.; PROVENCHER, L.S.; LEVIN, I.; ABPLANALP, H.; BRILES, R.W.; BRILES, W.E.; DODGSON, J.B. Characterization of a red jungle fowl by white leghorn backcross reference population for molecular mapping of the chicken genome. Poultry Science, v.72, p.334-348, 1993.

CROOIJMANS, R. Gene hunting: molecular analysis of the chicken genome. Wageningen, 2000. 150p Dissertation (D.) - Wageningen University.

CROOIJMANS, R.P.M.A.; DIJKHOF, R.J.M.; VAN DER POEL, J.J.; GROENEN, M.A.M. New microsatellite markers in chicken optimised for automated fluorescent genotyping. Animal Genetics, v.28, p.427-437, 1997.

DARVASI, A.; SOLLER, M. Selective genotyping for determination of linkage between a marker locus and a quantitative trait locus. Theoretical and Applied Genetics, v.85, p.353-359, 1992.

DE KONING, D.-J.; JANSS, L.L.G.; RATTINK, A.P.; VAN OERS, P.A.M.; VRIES, B.J.; GROENEN, M.A.M.; DER POEL, J.J.; GROOT, P.N.; BRASCAMP, E.W.; VAN ARENDONK, J.A.M. Detection of quantitative trait loci for backfat thickness and intramuscular fat content in pigs (Sus scrofa). Genetics, v.152, p.1679-1690, aug 1999. 
DE KONING, D.-J.; BOVENHUIS, H.; VAN ARENDONK, J.A.M. On the detection of imprinted quantitative trait loci in experimental crosses of outbred species. Genetics, v.161, p.931-938, jun 2002.

DEEB, N.; LAMONT, S.J. Genetic architecture of growth and body composition in unique chicken populations. The American Genetic Association, v.93, p.107-118, 2002.

DODGSON, J.B.; CHENG, H.H.; OKIMOTO, R. DNA marker technology: a revolution in animal genetics. Poultry Science, v.76, p.1108-1114, 1997.

EMARA, M.G.; KIM, H. Genetic markers and their application in poultry breeding. Poultry Science, v.82, p.952-957, 2003.

FALCONER, D.S.; MACKAY, T.F.C. Introduction to quantitative genetics. Edinburg Gate, Harlow: Longman Group, 1996. 464p.

FERREIRA, M.E.; GRATTAPAGLIA, D. Introdução ao uso de marcadores moleculares em análise genética. Brasília: EMBRAPA, 1998. 220p.

FNP CONSULTORIA \& COMÉRCIO. ANUALPEC 2002. Anuário da pecuária brasileira. São Paulo, 2003. 400p.

GIBBS, M.; DAWSON, D.A.; McCAMLEY, C.;WARDLE, A.F.; ARMOUR, J.A.L.; BURKE, T. Chicken microsatellite markers isolated from libraries enriched for simple tandem repeats. Animal Genetics, v.28, p.401-417, 1997.

GREEN, P.; FALLS, K.; CROOKS, S. .CRI-MAP Documentation version 2.4 St. Louis: Washington University School of Medicine, 1990. 1v. 
GRIFFIN, D.K.; HABERMAN, F.; MASABANDA, J.; O'BRIEN, P.; BAGGA, M.; SAZANOV, A.; SMITH, J.; BURT, D.W.; FERGUSON-SMITH, M.; WIENBERG, J. Micro- and macrochromosome paints generated by flow cytometry and microdissection: tools for mapping the chicken genome. Cytogenetics and Cell Genetics, v.87, p.278-281, 1999.

GRIFFITHS, A.J.F.; MILLER, J.H.; SUZUKI, D.T.; LEWONTIN, R.C.; GELBART, W.M. Introdução à genética. 7.ed. Rio de janeiro: Guanabara Koogan, 2002. 794p.

GROENEN, M.A.M.; CROOIJMANS, R.P.M.A.; VEENENDAAL, A.; CHENG, H.H.; SIWEK, M.; VAN DER POEL, J.J. A comprehensive microsatellite linkage map of the chicken genome. Genomics, v.49, p.265-274, 1998.

GROENEN, M.A.M.; CHENG, H.H.; BUMSTEAD, N.; BENKEL, B.F.; BRILES, W.E.; BURKE, T.; BURT, D.W.; CRITTENDEN, L.B.; DODGSON, J.; HILLEL, J.; LAMONT, S.; PONCE DE LEON, A.; SOLLER, M.; TAKAHASHI, H.; VIGNAL, A. A consensus linkage map of the chicken genome. Genome Research, v.10, p.137-147, 2000.

HAIN, H.S.; CRABBE, J.C.; BERGESON, S.E.; BELKNAP, J.K. Cocaineinduced seizure thresholds: quantitative trait loci detection and mapping in two populations derived from the C57BL/6 and DBA/2 mouse strains. The journal of farmacology and experimental Therapeutics, v.293, p.180-187, 2000.

HALEY, C.S.; KNOTT, S.A. A simple regression method for mapping quantitative trait loci in line crosses using flanking markers, Heredity, v.69, p.315-324, 1992. 
HALEY, C.S.; KNOTT, S.A.; ELSEN, J.M. Mapping quantitative trait loci in crosses between outbred lines using least squares, Genetics, v.136, p.1195-1207, Mar. 1994.

HAVENSTEIN, G.B.; FERKET, P.R.; SCHEIDELER, S.E.; LARSON, B.T. Growth, livability, and feed conversion of 1957 vs. 1991 broilers when fed " typical" 1957 and 1991 broiler diets. Poultry Science, v.73, p.1785-1794, 1994.

HILLEL, J. Map-based quantitative trait locus identification, Poultry Science, v.76, p.1115-1120, 1997.

HUGHES, A.L.; HUGHES, M.K. Small genomes for better flyers, Nature, v.377, p.391, Oct. 1995.

IKEOBI, C.O.N.; WOOLILIAMS, J.A.; MORRICE, D.R.; LAW, A.; WINDSOR, D.; BURT, D.W.; HOCKING, P.M. Quantitative trait loci affecting fatness in the chicken. Animal Genetics, v.33, p. 428-435, 2002.

KAPPES, S.M. Utilization of gene mapping information in livestock animals, Theriogenology, v.51, p. 135-147, 1999.

KIRKPATRICK, B.W.; MENGELT, A.; SCHULMAN,N.; MARTIN, L.C.A. Identification of quantitative trait loci for prolificacy and growth in mice. Mammalian Genome, v.9, p.97-102, 1998.

KNOTT, S.A.; MARKLUND, L.; HALEY, C.AS.; ANDERSSON, K.; DAVIES, W.; ELLEGREN, H.; FREDHOLM, M.; HANSSON, I.; HOYHEIM, B.; LUNDSTRÖM, K.; MOLLER, M.; ANDERSSON, L. Multiple marker mapping 
of quantitative trait loci in a croos between outbred wild boar and large white pigs. Genetics, v.149, p.1069-1080, Jun. 1998.

LANDER, E.S.; BOTSTEIN, D. Mapping mendelian factors underlying quantitative traits using RFLP linkage maps, Genetics, v.121, p.185-199, Jan. 1989.

LANDER, E.S.; KRUGLYAK, L. Genetic dissection of complex traits: guidelines for interpreting and reporting linkage results. Nature Genetics, v.11, p.241247, 1995.

LANDER, E.S.; GREEN, P.; ABRAHAMSON, J.; BARLOW, A.; DALY, M.J. MAPMAKER: an interactive computer package for constructing primary genetic linkage maps of experimental and natural populations. Genomics, v.1, p.174-181, 1987.

LEDUR, M.C.; ZANELLA, E.L.; SCHMIDT, G.S.; JAENISCH, F.R.F.; SAATKAMP, M.G.; BASSI, L.J.; COUTINHO, L.L. Peso e características de carcaça em linhagens utilizadas no desenvolvimento de populações referência para detecção de QTL em aves. Revista Brasileira de Ciência Avícola, Supl. 2, p.73, 2000.

LEVIN, I.; CRITTENDEN, L.B.; DODGSON, J.B. Genetic map of the chicken Z chromosome using random amplified polymorphic DNA (RAPD) markers, Genomics, v.16, p.224-230, 1993.

LEVIN, I.; SANTAGELO, L.; CHENG, H.; CRITTENDEN, L.B.; DODGSON, J.B. An autossomal genetic linkage map of the chicken. Journal of Heredity, v.85, p.79-85, 1994. 
LIU, B.H. Statistical genomics: linkage, mapping, and QTL analysis. Boca Raton: CRC Press, 1998. 611p.

LYNCH, M.; WALSH, B. Genetics and analysis opf quantitative traits. Sunderland: Sinauer Associates, 1998. 980p.

MACKAY, T.F.C. The genetic architecture of quantitative traits. Annual Reviews in Genetics, v.35, p.303-339, 2001.

MARSHALL, T.C.; SLATE, J.; KRUUK, L.B.E. Statistical confidence for likelihood based paternity inference in natural populations. Molecular Ecology, v.7, p.639-655, 1998.

MARSHALL, T.C.; SLATE, J.; KRUUK, L.B.E. CERVUS version 2.0 http://helios.bto.ed.ac.uk/evolgen/cervus/cervus.html. (12/ago/2001).

McELROY, J.P.; HARRY, D.E.; DEKKERS, J.C.M.; LAMONT, S.J. Molecular markers associated with growth and carcass traits in meat-type chickens (compact disc). In: WORLD CONGRESS ON GENETICS APPLIED TO LIVESTOCK PRODUCTION, 7., Montpellier, 2002. Papers. Montpellier: s.ed., 2002. (Session, 4: Poultry and rabbit breeding).

McPHERSON, M.J.; HAMES, B.D.; TAYLOR, G.R. PCR 2: a pratical approach. New York: Oxford University Press, 1995. 332p.

McPHERSON, M.J; QUIRKE, P.; TAYLOR, G.R. PCR: a pratical approach. New York: IRL Press, 1991. 371p. 
McQUEEN, H.A.; SIRIACO, G.; BIRD, A.P. Chicken microchomosomes are hyperacetylated early replicating and gene rich, Genome Research, v.8, p.621-630, 1998.

MOODY, D.E.; POMP, D.; NIELSEN, M.K.; VAN VLECK, L.D. Identification of quantitative trait loci influencing traits related to energy balance in selection and inbred lines of mice, Genetics, v.152, p.699-711, Jun. 1999.

MOORE; A.; HAIG, D. Genomic imprinting in mammalian development: a parental tug-of-war. Trends in Genetics, v.7, p.45-49, feb. 1991.

MURANTY, H.; GOFFINET, B. Selective genotyping for location and estimulation of the effect of a quantitative trait locus, Biometrics, v.53, p.629-643, Jun. 1997.

MURANTY, H.; GOFFINET, B.; SANTI, F. Multitrait and multipopulation QTL search using selective genotyping, Genetic Research of Cambridge, v.70, p.259-265, 1997.

PRIMMER, C.R.; RAUDSEPP, T.; CHOWDHARY, B.P. Low frequency of microsatellites in the avian genome, Genome Research, v.7, p.471-482, 1997.

SAS INSTITUTE. SASISTAT 2001: user`s guide: statistics version 8.2, (compact disc). Cary, 2001.

SEATON, G.; HALEY, C.S.; KNOTT, S.A.; KEARSEY, M.; VISSCHER, P.M. QTL Express. http://qtl.cap.ed.ac.uk. (01 dez. 2002) 
SEATON, G.; HALEY, C.S.; KNOTT, S.A.; KEARSEY, M.; VISSCHER, P.M. qtI express: mapping quantitative trait loci in simple and complex pedigrees. Bioinformatics, v.18, p.339-340, 2002.

SEWALEM, A.; MORRICE, D.M.; LAW, A.; WINDSOR, D.; Haley, C.S.; IKEOBI, C.O.N.; BURT, D.W.; HOCKING, P.M. Mapping of quantitative trait loci for body weight at three, six, and nine weeks of age in a broiler layer cross. Poultry Science, v.81, p.1775-1781, 2002.

SCHMID, M.; NANDRA, I.; GUTTENBACH, M.; STEILEIN, C.; HOEHN, H.; SCHARTL, M.; HAAF, T.; WEIGEND, S.; FRIES, R.; BUERSTEDDE, J.M.; WIMMERS, K.; BURT, D.W.; LAMONT, S.J.; LAW, A.; GRIFFIN, D.K.; BUMSTEAD, N.; KAUFMAN, J.; THOMSON, P.A.; BURKE, T.; GROENEN, M.A.M.; CROOIJMANS, R.P.M.A.; VIGNAL, A.; FILLON, V.; MORISSON, M.; PITEL, F.; TIXIER-BOICHARD, M.; LADJALI-MOHAMEDI, K.; HILLEL, J.; MAKI-TANILA, A.; CHENG, H.H.; DELANY, M.E.; BURNSIDE, J.; MIZUNO, S. First report on chicken genes and chromosomes 2000. Cytogenetics and Cell Genetics, v.90, p.169-218, 2000.

SIWEK, M.; CORNELISSEN, S.J.B.; NIEUWLAND, M.G.B.; BUITENHUIS, A.J.; BOVENHUIS, H.; CROIJMANS, R.P.M.A.; GROENEN, M.A.M.; DE VRIESREILINGH, PARMENTIER, H.K.; VAN DER POEL, J.J. Detection of QTL for immune response to sheep red blood cells in laying hens. Animal Genetics, v.34, p.422-428, 2003.

SOLLER, M.; GENIZI, A.; BRODY, T. On the power of experimental designs for the detection of linkage between marker loci and quantitative loci in crosses between inbred lines. Theoretical and Applied Genetics, v. 47, p.35-, 1976. 
SUZUKI, T.; KUROSAKI, K.A.; KOIDE, M.; SHIMADA, K.; KANSAKU, N.; NAMIKAWA, T.; MATSUDA, Y. Cytogenetic assignment of 29 functional genes to chicken microchomosomes by FISH, Cytogenetics and Cell Genetics, v.87, p.233-237, 1999.

TUISKULA-HAAVISTO, M.; HONKATUKIA, M.; KONING, D.J.; SCHULMAN, N.F.; MÄKI-TANILA, A. Mapping of quantitative trait loci affecting quality and production traits in eggs layers, Poultry science, v.81, p.919-927, 2002.

TATSUDA, K.; FUJINAKA, K. Genetic mapping of the QTL affecting body weight in chickens using a F2 family, British Poultry Science, v.42, p.333$337,2001$.

VALLEJO, R.L.; BACON, L.D.; LIU, H.C.; WITTER, R.L.; GROENEN, M.A.M.; HILLEL, J.; CHENG, H.H. Genetic mapping of quantitative trait loci affecting susceptibility to marek's disease virus induced tumors in F2 intercross chickens, Genetics, v.148, p.349-360, Jan. 1998.

VAN DER BECK, S.; VAN ARENDONK, J.A.M.; GROEN, A.F. Power of twoand three-generation QTL mapping experiments in an outbred population containing full-sib or half-sib families. Theoretical and Applied Genetics, v.91, p.1115-1124, 1995.

VAN KAAM, J.B.C.H.M.; VAN ARENDONK, J.A.M.; GROENEN, M.A.M.; BOVENHUIS, H.; VEREIJKEN, A.L.J.; CROOIJMANS, R.P.M.A.; VAN DER POEL, J.J.; VEENENDAAL, A. Whole genome scan for quantitative trait loci affecting body weight in chickens using a three generation design. Livestock Production Science, v.54, p.133-150, 1998. 
VAN KAAM, J.B.C.H.M.; GROENEN, M.A.M.; BOVENHUIS, H.; VEENENDAAL, A.; VEREIJKEN, A.L.J.; VAN ARENDONK, J.A.M. Whole genome scan in chickens for quantitative trait loci affecting growth and feed efficiency, Poultry Science, v.78, p.15-23, 1999a.

VAN KAAM, J.B.C.H.M.; GROENEN, M.A.M.; BOVENHUIS, H.; VEENENDAAL, A.; VEREIJKEN, A.L.J.; VAN ARENDONK, J.A.M. Whole genome scan in chickens for quantitative trait loci affecting carcass traits, Poultry Science, v.78, p.1091-1099, 1999b.

VISSCHER, P.M. THOMPSON, R. HALEY, C.S. Confidence intervals in QTL mapping by bootstrapping. Genetics, v.143, p.1013-1020, 1996.

WALLING, G.A.; ARCHIBALD, A.L.; CATTERMOLE, J.A.; DOWNING, A.C.; FINLAYSON, H.A.; NICHOLSON, D.; VISSCHER, P.M.; WALKER, C.A.; HALEY, C.S. Mapping of quantitative trait loci on porcine chromosome 4. Animal Genetics, v.29, p.415-424, 1998.

WALLING, A.G.; VISSCHER, P.M.; ANDERSSON, L.; ROTHSCHILD, M.F.; WANG, L.; MOSER, G.; GROENEN, M.A.M.; BIDANEL,J.-P.; CEPICA, S.; ARCHIBALD, A.L.; GELDERMANN, H.; DE KONING, D.J.; MILAN, D.; HALEY, C.S. Combined analyses of data from quantitative trait loci mapping studies: chromosome 4 effects on porcine growth and fatness. Genetics, v.155, p.1369-1378, jul. 2000.

WANG, L.; YU, T.-P.; TUGGLE, C.K.; LIU, H.-C.; ROTHSCHILD, M.F. A directed search for quantitative trait loci on chromosomes 4 and 7 in pigs. Journal of Animal Science, v.76, p.2560-2567, 1998. 
YONASH, N.; CHENG, H.H.; HILLEL, J.; HELLER, D.E.; CAHANER, A. DNA microsatellites linked to quantitative trai loci affecting antibody response and survival rate in meat-type chickens. Poultry science, v.80, p.22-28, 2001.

ZENG, Z.B. Theretical basis for separation of multiple linked gene effects in mapping quantitative trait loci. Proceedings of National Academy of Sciences USA, v.90, p.10972-10976, Dec. 1993.

ZHU, J.J.; LILLEHOJ, H.S.; CHENG, H.H.; POLLOCK, D.; SADJADI, M.; EMARA, M.G. Sreening for highly heterozygous chickens in outbred commercial broiler lines to increse detection power for mapping quantitative trait loci. Poultry Science, v.80, p.6-12, 2001. 


\section{APÊNDICES}




\section{APÊNDICE 1}

Protocolo: Extração de DNA de sangue pela metodologia de Hillel (1989).

11. Adicionar $50 \mu \mathrm{L}$ de sangue descongelado em tubos falcon de $15 \mathrm{~mL}$.

2. Acrescentar a cada alíquota $3 \mathrm{~mL}$ de THE (10 mM de TRIS, $100 \mathrm{mM}$ de EDTA), homogeneizar por inversão do tubo algumas vezes, adicionar $10 \mu \mathrm{L}$ de proteinase $\mathrm{K}(20 \mathrm{mg} / \mathrm{mL})$ e $30 \mu \mathrm{L}$ de de SDS $20 \%$. Incubar em "shaker" a $55^{\circ} \mathrm{C}$ por 12 horas.

3. Adicionar $3 \mathrm{~mL}$ de $\mathrm{PCl}$ (fenol:clorofórmio:isoamil, 25:24:1). Misturar bem e colocar em banho-maria a $55^{\circ} \mathrm{C}$ por 10 minutos. Remover os tubos do banho e misturar novamente.

4. Centrifugar os tubos a $2500 \mathrm{rpm}$ por 10 minutos.

5. Com o auxílio de uma pipetadora, transferir a fase aquosa para um novo tubo e extrair com $3 \mathrm{~mL}$ de $\mathrm{Cl}$ (clorofórmio:isoamil, 24:1).

6. Centrifugar os tubos a $2500 \mathrm{rpm}$ por 1 minuto. Repetir novamente os passos 5 e 6.

7. Com o auxílio de uma pipetadora, transferir a fase aquosa para um novo tubo e adicionar $0,3 \mathrm{~mL}$ de $\mathrm{NaCl} 5 \mathrm{M}$.

8. Adicionar $6 \mathrm{~mL}$ de álcool 95\% (deverá aparecer a "nuvem" de DNA neste momento).

9. Centrifugar os tubos a $3500 \mathrm{rpm}$ por 10 minutos e descartar o sobrenadante. Adicionar $5 \mathrm{~mL}$ de etanol $70 \%$ e agitar.

10. Centrifugar os tubos a 3500 rpm por 5 minutos e descartar o sobrenadante.

11. Secar os tubos à temperatura ambiente ou a $37^{\circ} \mathrm{C}$ (se secar demais não irá ressuspender).

12. Adicionar $3 \mathrm{~mL}$ de TE aos peletes de 4 DNA. Colocar os peletes para ressuspender "overnight" em um "shaker".

13. Ler em espectrofotômetro e testar a integridade do DNA em gel de agarose. 


\section{APÊNDICE 2}

\section{Protocolo: Extração de DNA pela metodologia de Hillel (1989), modificada.}

11. Adicionar $200 \mu \mathrm{L}$ de SSC $1 \mathrm{X}$ a $20 \mu \mathrm{L}$ de sangue descongelado, em tubo eppendorf.

2. Centrifugar por 2 minutos a 12000 rpm. Descartar o sobrenadante.

3. Ressuspender as células em $200 \mu \mathrm{L}$ de SSC $1 X$.

4. Centrifugar por 2 minutos a 12000 rpm. Descartar o sobrenadante.

5. Acrescentar $500 \mu \mathrm{L}$ de acetato de rans; agitar cuidadosamente até dissolver o precipitado.

6. Adicionar $50 \mu \mathrm{L}$ de SDS 10\%; misturar cuidadosamente por inversão.

7. Adicionar $500 \mu \mathrm{L}$ de fenol:clorofórmio (na capela); misturar bem até homogeneizar.

8. Centrifugar por 10 minutos a $12000 \mathrm{rpm}$.

9. Recuperar o sobrenadante e ransferi-lo para outro eppendorf.

10. Adicionar $1 \mathrm{~mL}$ de etanol absoluto, misturar por inversão; deixar precipitar a $-20^{\circ} \mathrm{C}$ durante uma hora e meia.

11. Centrifugar por 2 minutos a 12000 rpm;.descartar o etanol.

12. Lavar o precipitado com $500 \mu \mathrm{L}$ de etanol $70 \%$.

13. Centrifugar por 2 minutos a $12000 \mathrm{rpm}$; descartar o etanol $70 \%$.

14. Colocar o precipitado em estufa a $37^{\circ} \mathrm{C}$ por meia hora.

15. Ressuspender o precipitado em $300 \mu \mathrm{L}$ de TE. 


\section{APÊNDICE 3}

\section{Protocolo: Extração de DNA de sangue de aves por DNAzol}

1. Aliquotar $15 \mu \mathrm{L}$ de sangue (com EDTA 10\%), previamente descongelado e rapidamente vortexado, em tubo eppendorf de $1,5 \mathrm{~mL}$.

2. Adicionar $1 \mathrm{~mL}$ de DNAzol, agitando manualmente de forma vigorosa.

3. Dividir o conteúdo em 2 tubos, e adicionar a cada um deles mais $0,5 \mathrm{~mL}$ de DNAzol, agitando imediatamente.

4. Dividir o conteúdo novamente em 2 tubos e adicionar $0,5 \mathrm{~mL}$ de etanol absoluto a cada um deles.

5. Agitar os tubos por inversão várias vezes, para permitir a compactação da nuvem de DNA.

6. "Pescar" o DNA compactado com pipeta e adicionar ao tubo $1 \mathrm{~mL}$ de etanol $95 \%$.

7. Centrifugar por 10 minutos a $1000 x G$ e após descartar o sobrenadante; repetir novamente esse último passo de lavagem.

8. Secar o "pellet" obtido à temperatura ambiente por 15 minutos e ressuspendê-lo com $300 \mu \mathrm{L}$ de água Milli Q.

\section{Quando a eluição não for completa:}

9. continuando o protocolo anterior, adicionar ao tubo o mesmo volume líquido (300 $\mu \mathrm{L})$ de clorofórmio - álcool isoamílico (24:1).

10. Centrifugar por 5 minutos a 13000 rpm; transferir a fase aquosa para um novo tubo.

11. Acrescentar $30 \mu \mathrm{L}$ de $\mathrm{NaCl} 5 \mathrm{M}$ (um décimo do volume prévio).

12. Fazer duas lavagens, adicionando-se etanol 95\%, centrifugando a 13000rpm por 5 minutos e descartando o sobrenadante.

13. Secar o "pellet" por 15 minutos a temperatura ambiente e ressuspender em $300 \mu \mathrm{L}$ de água Milli $\mathrm{Q}$. 


\section{APÊNDICE 4}

\section{Protocolo: Extração de DNA de sangue de aves utilizando proteinase $\mathrm{K}$}

11. Aliquotar $20 \mathrm{uL}$ de sangue;

2. Adicionar $1,0 \mathrm{~mL}$ de tampão de lise de células vermelhas;

3. Centrifugar por 1 minuto a $13000 \mathrm{rpm}$. Descartar o sobrenadante e repetir os passos 1 e 2;

4. Lavar o pelete com $0,5 \mathrm{~mL}$ de água destilada;

5. Centrifugar 1 minuto, 13000 rpm; descartar o sobrenadante;

6. Ressuspender o pelete em 80 uL do tampão de proteinase-K (5x), 7 uL de proteinase-K (20mg/mL), 10 uL de SDS $20 \%$ e 283 uL de água destilada;

7. Incubar por 1 hora a $55^{\circ} \mathrm{C}$;

8. Adicionar $120 \mu \mathrm{L} \mathrm{NaCl} 5 \mathrm{M}$ e agitar no "vortex" por 15 segundos. Centrifugar a 13000 rpm por 5 minutos;

9. Transferir o sobrenadante para um novo tubo e adicionar $1 \mathrm{~mL}$ de etanol absoluto. Homogenenizar e centrifugar por 5 minutos a 13000 rpm;

10. Lavar com etanol 70\%; centrifugar a 13000 rpm por 3 minutos;

11. Descartar o sobrenadante, secar o pelete 15 minutos à temperatura ambiente; ressuspender em água.

Tampão de proteinase-K

- $0,375 \mathrm{M} \mathrm{NaCl}$

- $\quad 0,12$ M EDTA (pH8,0). 